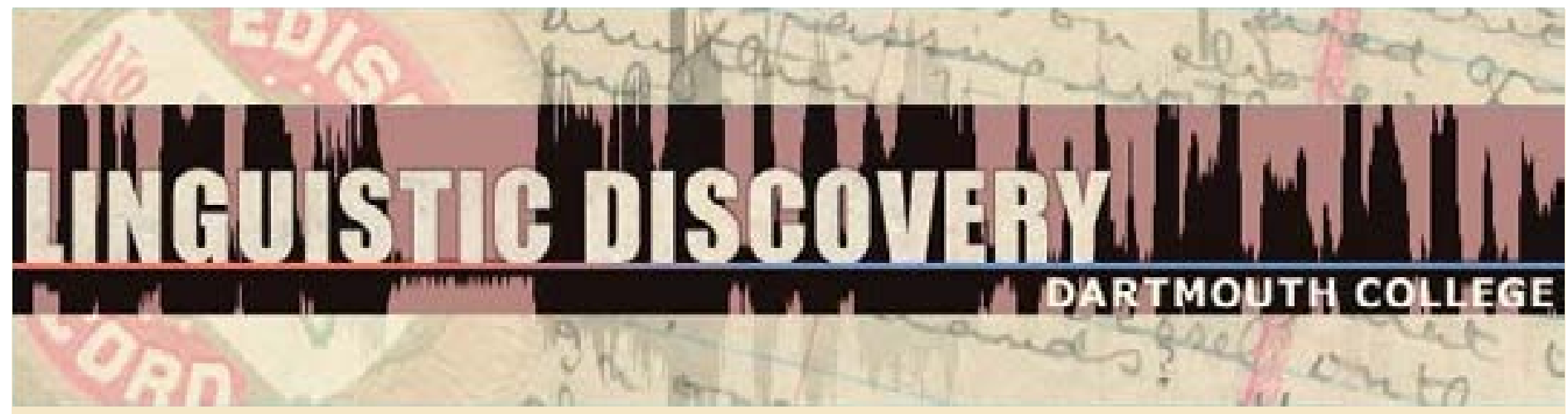

\begin{tabular}{|l|}
\hline Volume 10 \\
Issue 2 \\
2012 \\
\hline
\end{tabular}

\title{
Phonology Sketch and Classification of Lawu, an Undocumented Ngwi Language of Yunnan
}

Cathryn Yang

SIL International

doi: $10.1349 / P S 1.1537-0852 . A .410$

url: http://journals.dartmouth.edu/cgi-bin/WebObjects/ Journals.woa/1/xmlpage/1/article/410

\section{Linguistic Discovery}

Published by the Dartmouth College Library Copyright to this article is held by the authors. ISSN 1537-0852 linguistic-discovery.dartmouth.edu 


\section{Phonology Sketch and Classification of Lawu, an Undocumented Ngwi Language of Yunnan \\ Cathryn Yang \\ SIL International}

Lawu is a severely endangered, undocumented Ngwi (Loloish) language spoken in Yunnan, China. This paper presents a preliminary sketch of Lawu phonology based on lexico-phonetic data recorded from two speakers in 2008, with special attention to the tone splits and mergers that distinguish Lawu from other Ngwi languages. All tone categories except Proto-Ngwi Tone *3, a mid level pitch, have split, conditioned by the voicing of the initial segment. In the conditioning and effect of these tone splits, Lawu shows affinity with other Central Ngwi languages such as Lisu and Lahu and is provisionally classified as a Central Ngwi language.

\section{Introduction}

This report presents a preliminary phonological sketch of Lawu, an undocumented Ngwi (Loloish) language spoken in Shuitang District, Xinping County, Yuxi Municipality, and Jiujia District, Zhenyuan County, Pu'er Municipality, in Yunnan, China. Comparative phonological data is used to hypothesize Lawu's placement in the Central Ngwi $(\mathrm{CN})$ cluster within the Ngwi sub-branch of Tibeto-Burman. Like other Central Ngwi languages, such as Lolo, Lahu and Lisu, Lawu shows splits in Proto-Ngwi Tones $* 1$, $* 2$, and $*$ L, conditioned by voicing or glottal prefixation of the initial. However, Lawu has diachronically diverged from other CN languages, through the devoicing of Proto-Ngwi voiced stops and affricates, the merger of Proto-Ngwi palatoalveolar affricates and fricatives to alveolar, and the merger of Proto-Ngwi consonant clusters with plain stops, all of which result in a comparatively reduced inventory of initials. Lawu also shows later micro-splits in Tones $* 2$ and $*$ L, conditioned by voicing of the initial and vowel height. There is no linguistic documentation of Lawu, only passing mention of a distinct group in Chinese demographic sources (XPXZ 1993) and Pelkey's (1999) compilation of information on the Yi ethnicity. Although now ethnically categorized as Lahu, Lawu does not belong to the Lahoid language cluster (which includes Black Lahu, Yellow Lahu and Kucong). A distinct ISO 639-3 code for Lawu was applied for in July 2011. Hopefully this preliminary information will open the door for further investigation of this endangered language.

The Lawu data presented here was recorded in Jiuha Village, Shuitang District, Xinping County, Yuxi Municipality. Two native speakers recorded a list of 1,001 lexical items in 2008. These items were compared with Proto-Ngwi and lexical data from other Ngwi languages such as Hani (Southern Ngwi), Lisu (Central Ngwi), Lahu (Central Ngwi) (Sun 1991, Huang \& Dai 1992), and Nisu (Southeastern Ngwi, data from author's fieldnotes). Based on shared tonal innovations, I propose that Lawu is a member of the Central Ngwi subgroup, although further documentation and comparative analysis is needed to confirm this hypothesis.

\section{Background}

Lawu speaker population is difficult to estimate with accuracy. Lawu are now officially classified as members of the Lahu nationality, but were previously classifed as Yi (XPDZ 1986; XPXZ 1993). A government official in Jiuha Village reported approximately 300 "Lahu" in the village. 
Only the grandparental generation still speaks Lawu in Jiuha, so the Lawu speaker population there is probably 50 or less. There may be additional Lawu speakers in neighboring Zhenyuan County. According to the Gazetteer of Zhenyuan County (ZYXZ 1995: 74), there were 6,455 Lawu in Zhedong and Jiujia districts in 1995. However, a more recent demographic website (YSX 2008) identifies the Lahu in Zhedong as speakers of Kucong, a different language. Jiuha villagers reported the presence of Lawu speakers in Jiujia District, but not Zhedong. The Lahu population in Jiujia District, reported online as 3,288 (BDBK 2011) may contain both Kucong and Lawu speakers. Further fieldwork is needed for a more precise estimate of how many ethnic Lawu still speak the language.

Lawu is severely endangered, according to UNESCO's (2003, 2009) criteria for assessing language vitality and endangerment. Village leaders and wordlist participants in Jiuha Village were interviewed about the ethnolinguistic vitality of Lawu. Interview questions dealt with vitality indicators such as domains of language use, proficiency of children in Lawu, language attitudes, and contact with other languages. Only grandparents and older generations still speak the language; two generations ago, parents began speaking Chinese to their children in the hopes of giving them an advantage in school. Members of the current parental generation have some passive understanding of Lawu, but do not speak it to their children. Lawu is rarely spoken in the home domain, being only spoken between elderly spouses or friends. As most speakers are elderly and have trouble with mobility, they have few opportunities to leave their household to speak Lawu with their peers. Lawu speakers' attitudes towards their own language is laissezfaire; they do not mind if their grandchildren do not learn to speak Lawu.

There is no orthography for Lawu, and thus no educational materials in Lawu and no use of Lawu in any new print domains such as the Internet. There is no governmental or institutional support for Lawu; though the Chinese constitution gives minorities the right to develop their language, there is no monetary or administrative support for the Lawu to do so. Government encourages assimilation to the dominant language through the use of Mandarin Chinese only in the school. Chinese is used in all public domains, including village meetings. Besides this sketch, there is no documentation of Lawu whatsoever. Hopefully, more extensive documentation can begin before Lawu becomes extinct.

\section{Methodology}

Fieldwork was conducted in March 2008 as part of a research project on geographical variation in lesser-known Central Ngwi languages of western Yunnan, including Lalo, Lolo, Limi, and Lawu. Further details regarding this project are given in Yang 2010a. In Jiuha Village, one male and one female native speaker, both elderly, were asked to give Lawu equivalents to the Chinese prompts of a 1,001 item wordlist adapted from Pelkey 2008. The male speaker was recorded uttering lexical items in citation form, and the female speaker was recorded giving the lexical item in utterance medial form. The utterance medial form was embedded in one of several carrier phrases chosen for semantic plausibility and designed so that the elicited item was usually preceded by a syllable with mid level pitch, from Pelkey 2008. Both citation and utterance medial forms were repeated three times. An Edirol R-09 digital recorder was used to record in uncompressed .wav format.

Contrastive tone categories were determined during elicitation by asking speakers if lexical items that differed only in pitch and/or phonation were in fact minimal pairs. In the carrier phrase, the syllable preceding the elicited lexical item had a mid level pitch; by comparing the 
elicited item's pitch with the mid level pitch, I identified the tone categories of specific syllables. Comparison with lexical data from other Central Ngwi languages (Lolo, Lisu and Lahu (Huang \& Dai 1992)) and with Bradley's (1979) reconstruction of Proto-Ngwi also helped clarify which tone category a syllable belonged to. All Proto-Ngwi forms cited in this paper are from Bradley 1979.

For the acoustic tonal analysis, monosyllabic target words were used in both citation and utterance medial form. For each tone, approximately 30 tokens were used (on average 10 lexical items, with three repetitions), for an average of 150 tokens per speaker. Fundamental frequency (F0) measured in hertz (Hz) was extracted using Praat language software (Boersma \& Weenick 2009) and analyzed using procedures developed by Stanford (2008, 2011). Stanford's script in R (a free statistical software package) converts Hertz values to semitones, a logarithmic transformation that has been shown to better model speakers' intuitions about pitch difference than the Hertz scale (Nolan 2003). The speaker's mean pitch value of Tone 3, the mid-level tone, was defined as the zero level pitch value and thus served as the benchmark for normalized pitch (Stanford 2008). Stanford's script divides the pitch token into 600 equally spaced locations throughout the vowels' duration, and cuts off the first $25 \%$ of the vowel onset and the last $10 \%$ of vowel offset to avoid syllable edge effects. Similar to Stanford's (2008) study of Sui, the tone tokens in this study had a mix of onsets in terms of voicing and sonority; therefore, a larger portion of the onset was omitted, as different onsets have been shown to locally affect F0 (Hombert 1978, Hombert et al. 1979). For each tone category, pitch values were averaged for all tokens at each normalized time point. The tonal inventories in Figure 3 and Figure 4 are presented in semitones and normalized for duration and mean Tone 3 F0. When transcribing tone, Chao's (1930) system of pitch numbers is used to represent the relative pitch height of the tone (1 is low and 5 is high).

\section{Phonology Sketch}

Lawu's syllable template is $(\mathrm{C}) \mathrm{V}(\mathrm{y})$ with suprasegmental tone. There are 22 initial consonants, six monophthongs that may be followed by $-n$, five diphthongs, and four tones. Like other Central Ngwi languages (Matisoff 2003), Lawu has lost Proto-Ngwi syllable-final consonants. Only a few instances of Proto-Ngwi *-n are preserved, as in kəך ${ }^{33}$ 'bracelet' from Proto-Ngwi ${ }^{*}$ gon ${ }^{1}$.

\subsection{Initials}

Table 1 gives the inventory of initials in Lawu, with allophones in brackets. Alveolar and alveopalatal obstruents are contrastive before all vowels except /e/; before /e/, only the alveopalatal occurs. The alveolar series does not occur before [i], as the allophone of /i/ after alveolar affricates and fricatives is [1], an apical anterior vowel (Lee 2005). The female speaker distinguished between alveolars and alveopalatals before /i/ (i.e. [t6i] and [ts]] were distinct in her pronunciation), but the male speaker had merged both syllables in favor of [t6i]. There are no examples of [t6a] in the wordlist, but $/ \mathrm{t} 6 /$ contrasts with /ts/ before all other vowels, e.g. tso $^{55}$ 'drill a hole' contrasts with $t 6 O^{55}$ 'lean (adj.), and $t s u^{33}$ 'teach/train' contrasts with $t 6 u^{33}$ 'cold (adj.)'.

/f/ has a restricted distribution, only appearing before close vowels /i/ and /u/. It is contrastive with /x/ before /i/: compare $a^{55} \mathrm{fi}^{33}$ 'left' with $x i^{33}$ 'situated crooked,' and with /s/ before both /i/ 
and /u/: compare $f u^{55}$ 'swell,' $s u^{55}$ 'iron' and $a^{21} s 7^{33}$ 'who?'. Southwestern Mandarin likewise has no opposition between [xu] and [fu]; /x/ before [u] is pronounced as [f] (Ho 2003:130). There is a gap in the inventory, with no voiced alveopalatal fricative [z]. Proto-Ngwi $*_{3}$, the most likely source for [z], instead is usually reflected as palatal glide [j] (e.g., * zak $^{\mathrm{L}}$ 'descend'> ja ${ }^{33}$ ), thus merging with some reflexes of $* \mathrm{y} . / \mathrm{n} /$ is realized as $[\mathrm{n}]$ before close front vowel $/ \mathrm{i} / \mathrm{and} / \mathrm{e} /$. Table 2 gives lexical examples of Lawu initial consonants.

\begin{tabular}{|c|c|c|c|c|c|}
\hline & labial & alveolar & alveopalatal & palatal & velar \\
\hline \multicolumn{6}{|l|}{ stops } \\
\hline voiceless unaspirated & $\mathrm{p}$ & $\mathrm{t}$ & & & $\mathrm{k}$ \\
\hline voiceless aspirated & $\mathrm{p}^{\mathrm{h}}$ & $t^{\mathrm{h}}$ & & & $\mathrm{k}^{\mathrm{h}}$ \\
\hline \multicolumn{6}{|l|}{ affricates } \\
\hline voiceless unaspirated & & ts & t6 & & \\
\hline voiceless aspirated & & $\mathrm{ts}^{\mathrm{h}}$ & $t 6^{\mathrm{h}}$ & & \\
\hline \multicolumn{6}{|l|}{ fricatives } \\
\hline voiceless & $\mathrm{f}$ & $\mathrm{s}$ & 6 & & $\mathrm{x}$ \\
\hline voiced & $\mathrm{v}$ & $\mathrm{z}$ & & & \\
\hline nasal sonorants & $\mathrm{m}$ & $\mathrm{n}[\mathrm{n}]$ & & & $y$ \\
\hline oral sonorants & $\mathrm{w}$ & 1 & & $\mathrm{j}$ & \\
\hline
\end{tabular}

\begin{tabular}{lll|lll}
\hline Initial & Lawu & English & Initial & Lawu & English \\
\hline $\mathrm{p}$ & $\mathrm{pa}^{55}$ & exchange & $\mathrm{f}$ & $\mathrm{fu}^{55}$ & swell \\
$\mathrm{p}^{\mathrm{h}}$ & $\mathrm{p}^{\mathrm{h}} \mathrm{a}^{33}$ & leaf & $\mathrm{v}$ & $\mathrm{va}^{21}$ & snow \\
$\mathrm{t}$ & $\mathrm{ta}^{55}$ & carry in arms & $\mathrm{s}$ & $\mathrm{sa}^{33}$ & poor \\
$\mathrm{t}^{\mathrm{h}}$ & $\mathrm{t}^{\mathrm{h}} \mathrm{a}^{55}$ & sharp & $\mathrm{z}$ & $\mathrm{za}^{33}$ & chicken \\
$\mathrm{k}$ & $\mathrm{ka}^{55}$ & scratch & $\mathrm{G}$ & $\mathrm{ca}^{21}$ & know \\
$\mathrm{k}^{\mathrm{h}}$ & $\mathrm{k}^{\mathrm{h}} \mathrm{a}^{55}$ & hard & $\mathrm{x}$ & $\mathrm{xa}^{33}$ & borrow \\
$\mathrm{ts}$ & $\mathrm{tsa}^{33}$ & boil & $\mathrm{m}$ & $\mathrm{ma}^{21}$ & NEG \\
$\mathrm{ts}^{\mathrm{h}}$ & $\mathrm{ts}^{\mathrm{h}} \mathrm{a}^{33}$ & dirty & $\mathrm{n}$ & $\mathrm{na}^{21}$ & many \\
$\mathrm{t} 6$ & $\mathrm{tc}^{55}$ & drill a hole & $\mathrm{y}$ & $\mathrm{ya}^{33}$ & 1 SG \\
$\mathrm{t} \mathrm{c}^{\mathrm{h}}$ & $\mathrm{tc}^{\mathrm{h}} \mathrm{a}^{33} \mathrm{tu}^{21}$ & fire pit & $\mathrm{l}$ & $\mathrm{la}^{33}$ & come \\
$\mathrm{j}$ & $\mathrm{ja}^{33}$ & descend & $\mathrm{w}$ & $\mathrm{ka}^{21} \mathrm{wa}^{33}$ & outside \\
\hline
\end{tabular}

Table 3 summarizes the development of manner of articulation of Lawu stops and affricates, compared with other CN languages (Matisoff 2003:17). Bilabial stops (P, Ph, B) are used in the table to represent all places of articulation for stops and affricates. ${ }^{*} \mathrm{C}$ is a cover symbol for the Proto-Tibeto-Burman voiced consonantal prefixes *b, *d, *g, *r, *l (Bradley 1979). *m- 
represents the Proto-Ngwi homorganic nasal prefix. Proto-Ngwi voiced and nasal prefixed stops and affricates have unconditionally devoiced in Lawu, so that Lawu no longer has any voiced stops and affricates, unlike most other $\mathrm{CN}$ languages. This development may be due to the influence of Southwestern Mandarin, whose voiced stops and affricates have also devoiced. Other languages Lawu is in contact with, i.e. Nisu and Lolo, have retained voiced onsets. The devoicing of voiced stops and affricates was the trigger for the phonologization of the tone splits described in Section 4.3.

\begin{tabular}{llll}
\hline Proto-Ngwi & Lawu & Lahu & Lalo, Lisu, Lolo \\
\hline$* \mathrm{P},{ }^{*} \mathrm{C}-\mathrm{P}$ & $\mathrm{P}^{\mathrm{h}}$ & $\mathrm{P}^{\mathrm{h}}$ & $\mathrm{P}^{\mathrm{h}}$ \\
$* 2 \mathrm{~B}, * 2 \mathrm{P}$ & $\mathrm{P}$ & $\mathrm{P}$ & $\mathrm{P}$ \\
* $_{\mathrm{B},}^{*}$ C-B & $\mathrm{B}>\mathrm{P}$ & $\mathrm{P}$ & $\mathrm{B}$ \\
${ }^{*} \mathrm{~m}-\mathrm{B},{ }^{*} \mathrm{~m}-\mathrm{P}$ & $\mathrm{B}>\mathrm{P}$ & $\mathrm{B}$ & $\mathrm{B}$ \\
\hline \multicolumn{4}{c}{ Table 3: Development of manner of stops and affricates in Central Ngwi }
\end{tabular}

Proto-Lawu had preglottalized sonorants $* ? \mathrm{~m}, * ? \mathrm{n}$, $* 2 \mathrm{l}$, and $* ? \mathrm{w}$, a coalescence of the ProtoNgwi $* 2$ or $*$ s- prefixes before sonorants. Preglottalization has since been lost in Lawu, but at the time of the Lawu tone splits (see Section 4.3), preglottalization blocked the lowering of the pitch seen in plain voiced sonorants. Modern pitch reflexes in syllables with Proto-Lawu preglottalized sonorants match those of voicless initials rather than voiced, e.g. Proto-Lawu *2la ${ }^{1}$ 'spirit' $>1 a^{55}$ and $* \mathrm{pa}^{1}$ ' exchange' $>\mathrm{pa}^{55}$ versus $* 1 \mathrm{a}^{1}$ 'come' $>1 \mathrm{la}^{33}$.

Table 4 summarizes the Proto-Ngwi sources of Lawu initials. The majority of Proto-Ngwi consonant clusters of stop plus *-1, *-r, *-y have merged with the simple stops. Only *ky and *gy palatalized to the alveopalatal affricate before close vowels (e.g., *ky $>t_{6} / *_{i}$, e, o) and merged with the alveolar affricates before rhymes with *a (e.g., *gyaw 'waist' > [tso $\left.{ }^{21}\right]$; *kyaj ${ }^{2}$ 'friend' $\left.>\left[\mathrm{ts}^{\mathrm{h}} \mathrm{u}^{21}\right]\right)$. Palatoalveolar affricates and fricatives merge with the alveolar series $\left(* \mathrm{c}>/ \mathrm{ts} /\right.$ and $* \int$ $>/ \mathrm{s} /$ ). Before rhymes *a and *ay, *my merges with *n to /n/. Proto-Ngwi resonants *r and *y become fricatives before back vowels, with the place of articulation conditioned by the vowel, e.g., *r and $*_{\mathrm{y}}>\mathrm{v} /{ }_{-}{ }^{\mathrm{u}} \mathrm{u}$ and $>\mathrm{z} / *_{-}$-a-. Elsewhere, ${ }^{*} \mathrm{r}$ becomes $/ \mathrm{y} /$, and $*^{\mathrm{y}}$ remains a palatal glide /j/. ${ }^{*} \mathrm{w}$ also becomes a fricative, usually /v/. ${ }^{*} \mathrm{~h}$ merges with ${ }^{*} \mathrm{x}$, and becomes /6/ before high front vowels. Labial prefixes preempt initial liquids *l and *r, with both $* b$ and $* m$ becoming a labial stop, e.g., *b-le 'four' $>\left[\mathrm{pi}^{21}\right],{ }^{*} \mathrm{~m}-\mathrm{le}^{2}$ 'grandchild'> [pi $\left.{ }^{21}\right],{ }^{*} \mathrm{~m}-\mathrm{rwe}^{1}$ 'snake' $>\left[\mathrm{pe}^{33}\right]$. This suggests an early merger in Proto-Lawu of the $* \mathrm{~m}$ - and $* \mathrm{~b}$ - prefixes to an initial $* \mathrm{~b}$. Labial stops before ${ }^{*} \mathrm{~W}$ became labiodental fricatives, as in $* \mathrm{~b}$-way ${ }^{2}$ 'left' $>*_{\mathrm{vi}}{ }^{33}>\left[\mathrm{fi}^{33}\right]$ and $* \mathrm{C}$-pwam ${ }^{2}$ 'swell' $>\left[\mathrm{fu}^{55}\right]$. Similarly, glottalized *2-pl becomes /f/ in *2-plu' 'porcupine,' but plain *plu ${ }^{1}$ 'silver/white' merges with $/ \mathrm{p}^{\mathrm{h}} /$, becoming $\left[\mathrm{p}^{\mathrm{h}} \mathrm{u}^{55}\right]$. 


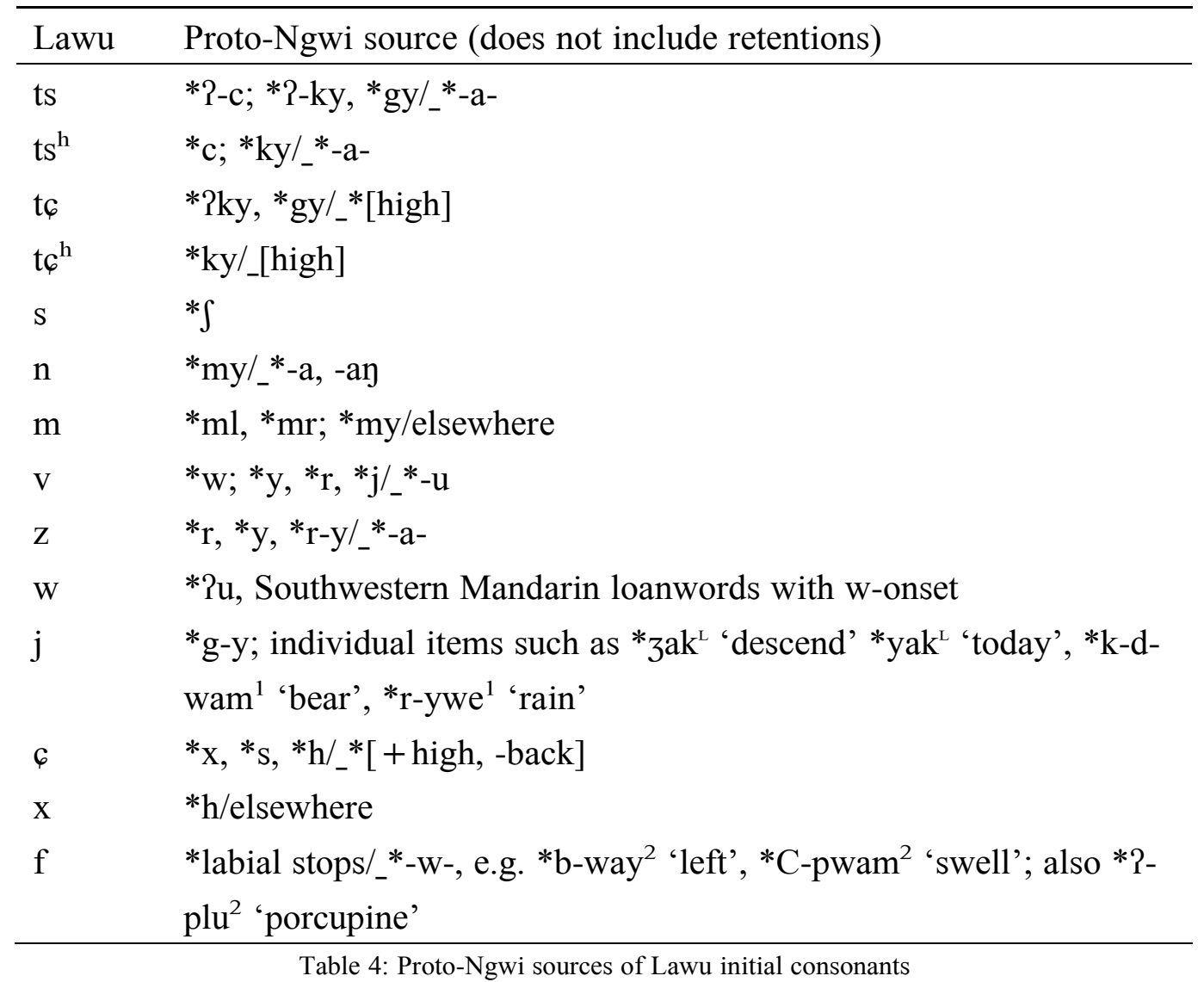

\subsection{Rhymes}

Lawu has six monophthongs and five diphthongs, given in Table 5. All monophthongs can be followed by the velar nasal $-n$ except $-u-$. Diphthongs may be followed by the velar nasal in Chinese loanwords (e.g., $\mathrm{p}^{\mathrm{h} a{ }^{21}}{ }^{\mathrm{kuan}}{ }^{33}$ 'bladder'), but not in native vocabulary. Lawu is unlike most other Central Ngwi languages in having a contrastive nasal final. In a few items, Proto$\mathrm{Ngwi}^{*} \mathrm{n}$ has been retained, as in $p \partial \eta^{33}$ 'full' from Proto-Ngwi *m-blin ${ }^{3}$ and $t s a \eta^{55}$ 'tree' from Proto-Ngwi ${ }^{*}$ dzin ${ }^{1}$. The nasal final is also seen in Chinese loanwords, e.g. $6 a \eta^{21} f^{21}$ 'blessed, happy,' and in some words whose diachronic origin is unclear (e.g. $p^{h} i^{33}$ 'knife'). In originally open syllables beginning with nasal stops, a nasal final has been added after back vowel *o, e.g. ${ }^{*} \mathrm{~s}-\mathrm{mo}^{1}$ 'mushroom' $>m \partial \eta^{55}$, and ${ }^{*} \mathrm{C}-\mathrm{no}^{2}$ 'awake' $>n \partial \eta^{21}$. The close vowel [i] is realized as apical vowel [1] after alveolar affricates and sibilants (i.e. /z, s, ts and ts $\mathrm{s}^{\mathrm{h}}$ ). Table 6 gives examples showing minimal or near minimal pairs.

\begin{tabular}{llll}
\hline & Monophthongs & Diphthongs \\
\hline $\mathrm{i}[1]$ & & $\mathrm{u}$ & $\mathrm{ue}, \mathrm{ie}$ \\
$\mathrm{e}$ & $\partial$ & $\mathrm{o}$ & \\
& $\mathrm{a}$ & & au, ai, ua \\
\hline
\end{tabular}

Table 5: Inventory of rhymes in Lawu 


\begin{tabular}{|c|c|c|c|c|c|}
\hline Initial & Lawu & English & Initial & Lawu & English \\
\hline $\mathrm{i}$ & $\mathrm{ki}^{33}$ & open & in & $\operatorname{xin}^{55}$ & lean against \\
\hline $\mathrm{e}$ & $\mathrm{ke}^{55}$ & suffix for hen & en & $\operatorname{ken}^{21}$ & busy \\
\hline ə & $\mathrm{k} \partial^{33}$ & boil & əท & ${\mathrm{k} ə \mathrm{y}^{55}}^{55}$ & snap in two \\
\hline $\mathrm{a}$ & $\mathrm{ka}^{55}$ & scratch & ay & $\mathrm{y}^{55} \mathrm{ka \eta}^{55}$ & between \\
\hline $\mathrm{u}$ & $\mathrm{ku}^{21}$ & nine & on & $\mathrm{koy}^{33} \mathrm{tsa}^{55}$ & thread \\
\hline o & $\mathrm{ko}^{21}$ & buckwheat & $\mathrm{au}$ & $\mathrm{kau}^{33}$ & in front \\
\hline ue & $\mathrm{tue}^{55}$ & exit & $\mathrm{ai}$ & $\mathrm{kai}^{33}$ & very \\
\hline ie & $\mathrm{pie}^{33}$ & explode & & & \\
\hline
\end{tabular}

The following near minimal pairs further distinguish phonetically similar rhymes:

1. Front vowels:

$$
\begin{aligned}
& \mathrm{a}^{21} \mathrm{pi}^{33} \text { 'duck' } \\
& \text { pie }^{33} \text { 'explode' } \\
& \text { pe }^{33} \text { 'snake' } \\
& \text { pin }^{33} \mathrm{kaj}^{55} \text { 'rainbow' }
\end{aligned}
$$

2. Back vowels:

$$
\begin{aligned}
& \text { tu }^{21} \text { 'dig a hole' } \\
& \text { tue }^{55} \text { 'exit' }
\end{aligned}
$$

Table 7 gives the Proto-Ngwi sources for Lawu rhymes, arranged in order of decreasing frequency in the 1,001-item wordlist. I compared the Lawu lexical data to Bradley's (1979) Proto-Ngwi reconstructed vocabulary of 866 items to determine the Lawu reflexes of ProtoNgwi rhymes. The monophthongs [e] and [o] have fewer diachronic sources than [i] and [u] and are less frequent than other monophthongs. Monophthongs are more frequent than diphthongs or nasal final rhymes. Some nasal final rhymes and diphthongs occur only rarely, such as [en] and [ua], which have only one example each in the wordlist. 


\begin{tabular}{|c|c|c|c|}
\hline Rhyme & Proto-Ngwi source & $\begin{array}{l}\text { Number } \\
\text { of tokens }\end{array}$ & Frequency \\
\hline $\mathrm{a}$ & $* \mathrm{a}, * \mathrm{ak}, * \mathrm{yak}$ & 378 & $29 \%$ \\
\hline $\mathrm{i}$ & $*_{\text {ay, }} *_{\text {at }} *_{\mathrm{wat}} *_{\mathrm{an}}, *_{\mathrm{wan}}, *_{\mathrm{i}}, *_{\mathrm{it}}, *_{\mathrm{ik}}, *_{\mathrm{e}}, *_{\mathrm{ek}}, *_{\mathrm{ut}}$ & 277 & $21 \%$ \\
\hline $\mathrm{u}$ & $\begin{array}{l}{ }^{*} \mathrm{u},{ }^{*} \mathrm{um}, * \mathrm{ok}, * \mathrm{uk}, *_{\mathrm{wak},} *_{\mathrm{am},}{ }^{*} \mathrm{yam}, * \mathrm{aj} \\
*_{\mathrm{o}} \text { elsewhere }\end{array}$ & 214 & $16 \%$ \\
\hline$\partial$ & $*_{\mathrm{uk}} *_{\mathrm{ay}}, *_{\mathrm{ut}}, *_{\mathrm{i},} *_{\mathrm{it},} *_{\mathrm{ok}}, *_{\mathrm{we}}, *_{\mathrm{e}} / *_{\mathrm{r}}$ & 169 & $13 \%$ \\
\hline o & $*$ aw, $*$ ap, $*_{\text {yup }} *_{\text {yok }}$ & 89 & $7 \%$ \\
\hline əท & $\begin{array}{l}{ }^{*} \mathrm{o} /{ }^{*} \text { nasal_; }{ }^{*} \mathrm{ij} /{ }^{*} \mathrm{bl},{ }^{*} \mathrm{kr}_{-} ; * \mathrm{in} / *_{\mathrm{ts}},{ }^{*} \mathrm{dz}_{-} ; \text {individual } \\
\text { items such as }{ }^{*} \mathrm{doy}^{1} \text { 'wing', }{ }^{*} \text { mun }^{1} \text { 'flour' }\end{array}$ & 83 & $6 \%$ \\
\hline e & $\begin{array}{l}*_{\mathrm{et}} ;{ }^{*} \text { at } / *_{\mathrm{ts}},{ }^{*} \mathrm{~s}_{-} ; *_{\mathrm{ok}} / *_{\mathrm{m}},{ }^{*} \mathrm{n}_{-} ; \text {individual items such } \\
\text { as } *^{*} \mathrm{~m}-\mathrm{rwe}^{1} \text { 'snake', Tibeto-Burman } *^{*} \text { trek 'thunder' }\end{array}$ & 35 & $3 \%$ \\
\hline ay & Chinese loans and unknown sources & 20 & $2 \%$ \\
\hline ai & $\begin{array}{l}\text { Chinese loans and unknown sources, individual } \\
\text { item } * \mathrm{dak}^{\mathrm{H}} \text { 'ascend' }\end{array}$ & 9 & $0.7 \%$ \\
\hline oy & unknown source, individual item *hom 'fragrant' & 8 & $0.6 \%$ \\
\hline in & Chinese loans and unknown sources & 7 & $0.5 \%$ \\
\hline ie & $\begin{array}{l}\text { unknown sources; individual items such as *b-ni } \\
\text { 'near', }{ }^{2}{ }_{\mathrm{S}-\text { nok }^{\mathrm{H}} \text { 'bean' }}\end{array}$ & 5 & $0.4 \%$ \\
\hline ue & $\begin{array}{l}\text { unknown sources; individual items such as *?- } \\
\text { dwak }^{\mathrm{H}} \text { 'take out' }\end{array}$ & 5 & $0.4 \%$ \\
\hline ey & unknown source & 1 & $0.1 \%$ \\
\hline ua & Chinese loan & 1 & $0.1 \%$ \\
\hline $\mathrm{au}$ & unknown source & 1 & $0.1 \%$ \\
\hline
\end{tabular}

\subsection{Tones}

This section gives an acoustic analysis of the Lawu tonal system and describes Lawu's complex tone splits and mergers. Lawu has four contrastive tones: three level pitches (high, mid, low) in modal phonation and one mid falling pitch in harsh phonation. Compared to other Central Ngwi languages, this tonal inventory is rather small: Lahu has seven (Matisoff 1982 [1973]), Lisu six (Bradley 2003), Central Lalo five (Yang 2010a). The reduced number of tones is due to the unconditioned merger of Proto-Ngwi Tones $* 1$ and $* \mathrm{H}$, and the multiple mergers with Tone $* 3$ that occurred after the splits in Tones $* 2$, $* \mathrm{~L}$, and $* 1 / \mathrm{H}$.

The Proto-Ngwi tonal system had a three-way pitch height contrast in syllables ending in vowels or nasals: Tones $* 1(* \mathrm{~T} 1$, high), $* 2$ (*T2, low), and $* 3$ (*T3, mid) (Bradley 1977). In syllables ending in *-p, *-t, and *-k, Proto-Ngwi had two distinct tone categories, *Low-stopped $(* \mathrm{TL})$ and $*$ High-stopped $(* \mathrm{TH})$ (Matisoff 1972). In most Ngwi languages, syllable-final *stops 
merged to a glottal stop and then to laryngealized vocal register on the vowel, often seen as harsh (or tense) phonation. Harsh phonation is marked with an underscore under the vowel, e.g., [a] ].

Harsh phonation is an aperiodic phonatory quality produced when the laryngeal sphincter (i.e., the thyroarytenoid muscle complex) is constricted and the ventricular folds incur over the vocal folds (Edmondson \& Esling 2006: 162). High levels of jitter (irregularity in the duration of the glottal pulse cycle), shimmer (irregularity in amplitude), and high-frequency energy are acoustic correlates of harsh (Scherer 1986). In some Ngwi languages, such as Lalo (Yang 2010b), harsh phonation also correlates with increased pitch and shorter duration, compared to modal phonation. Figure 1 below gives the spectrogram of the male speaker's utterance of [na ${ }^{31}$ ] 'sticky', in harsh phonation. Note the blacker regions at high-frequency levels, reflecting highfrequency energy. Harsh [na ${ }^{31}$ ] has $2.7 \%$ local jitter and $12.8 \%$ local shimmer, measured with Praat. In comparison, modal [na ${ }^{21}$ ' rich' (spectrogram seen in Figure 2) has only 1.2\% jitter and $8.3 \%$ shimmer.

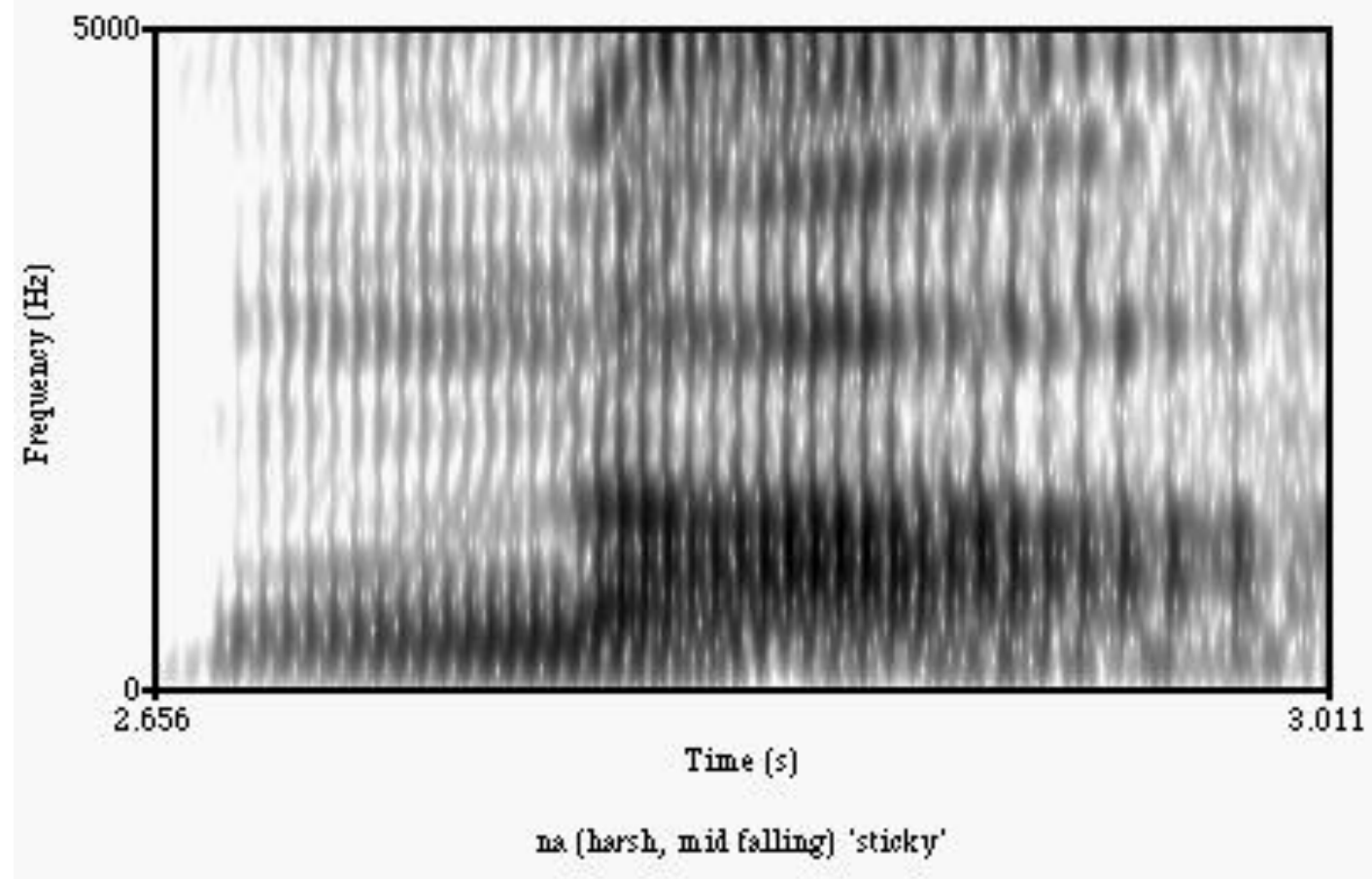

Figure 1: Spectrogram of $\left[\mathrm{na}^{31}\right]$ 'sticky' by male speaker 


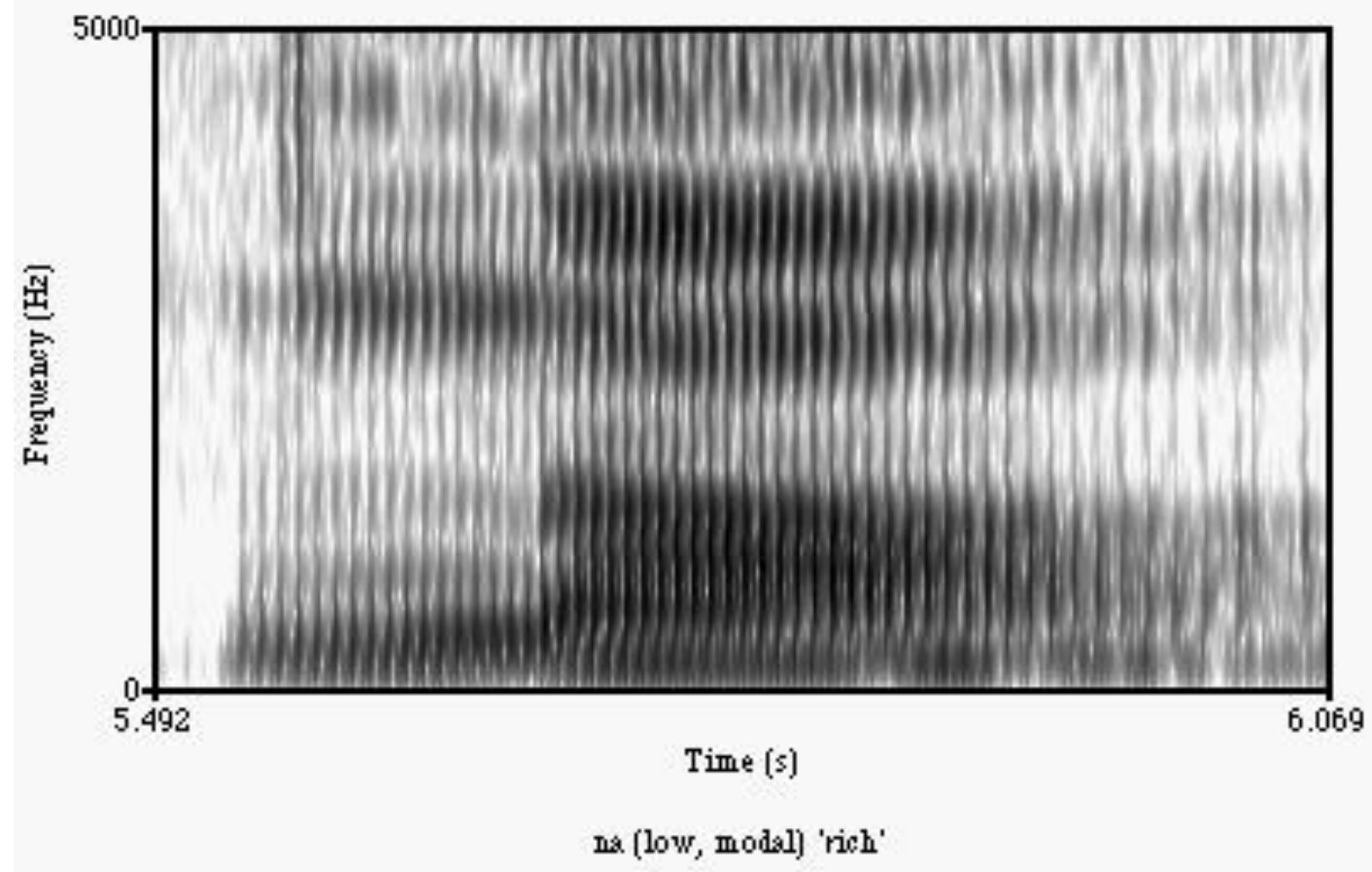

Figure 2: Spectrogram of $\left[\mathrm{na}^{21}\right]$ 'rich' by male speaker

Figure 3 and Figure 4 show the acoustic tonal analysis of the male and female speaker, respectively, using the methodology described in Section 3. $\mathrm{N}$ is the number of tokens used in the analysis. Lawu's synchronic tone categories are abbreviated without asterisks as T1/TH (a merger of $* \mathrm{~T} 1$ and $* \mathrm{TH}), \mathrm{T} 2, \mathrm{~T} 3$, and TL. The male speaker's tokens were all in citation form, and the female speaker's were in utterance medial form. In Figure 3, the merged T1/TH category is a high level pitch, and T3 a mid level pitch. T2 starts low and gradually falls to the bottom of the pitch range, while TL starts at the mid pitch and falls rapidly. TL is pronounced with slight harsh phonation, with a higher pitch onset and shorter duration than modal T2. The average duration for the male's TL tokens is roughly $75 \%$ of the duration of the average T2 token, and the duration difference between TL and T2 is statistically significant ( $p<0.01)$. In the figures below, durations are normalized to depict relative differences, so TL is depicted in Figure 3 as $25 \%$ shorter in duration than the other tones.

Figure 4 below, based on the female speaker's utterance medial forms, shows some differences from Figure 3. Acoustic analysis of additional speakers from both genders uttering citation and utterance medial forms is needed to investigate the cause of the differences. With the current limited data, I cannot conclude whether the differences are related to gender or to the phonetic environment of the token used. Unlike the male speaker, the female speaker's TL and T2 do not differ in their duration. Although the female's mean TL pitch is still higher than the mean T2 pitch at a 0.05 level of significance, TL's pitch onset in Figure 4 is lower than the mid pitch onset seen in Figure 3. One possible explanation for the differences is that harsh phonation may be neutralized in utterance-medial speech. This neutralization also occurs in some Lalo languages (Yang 2010a: 180) and Phula languages (Pelkey 2011). The eventual loss of harsh phonation would not be surprising, as SW Mandarin, the language that is currently replacing Lawu, does not have harsh phonation. 


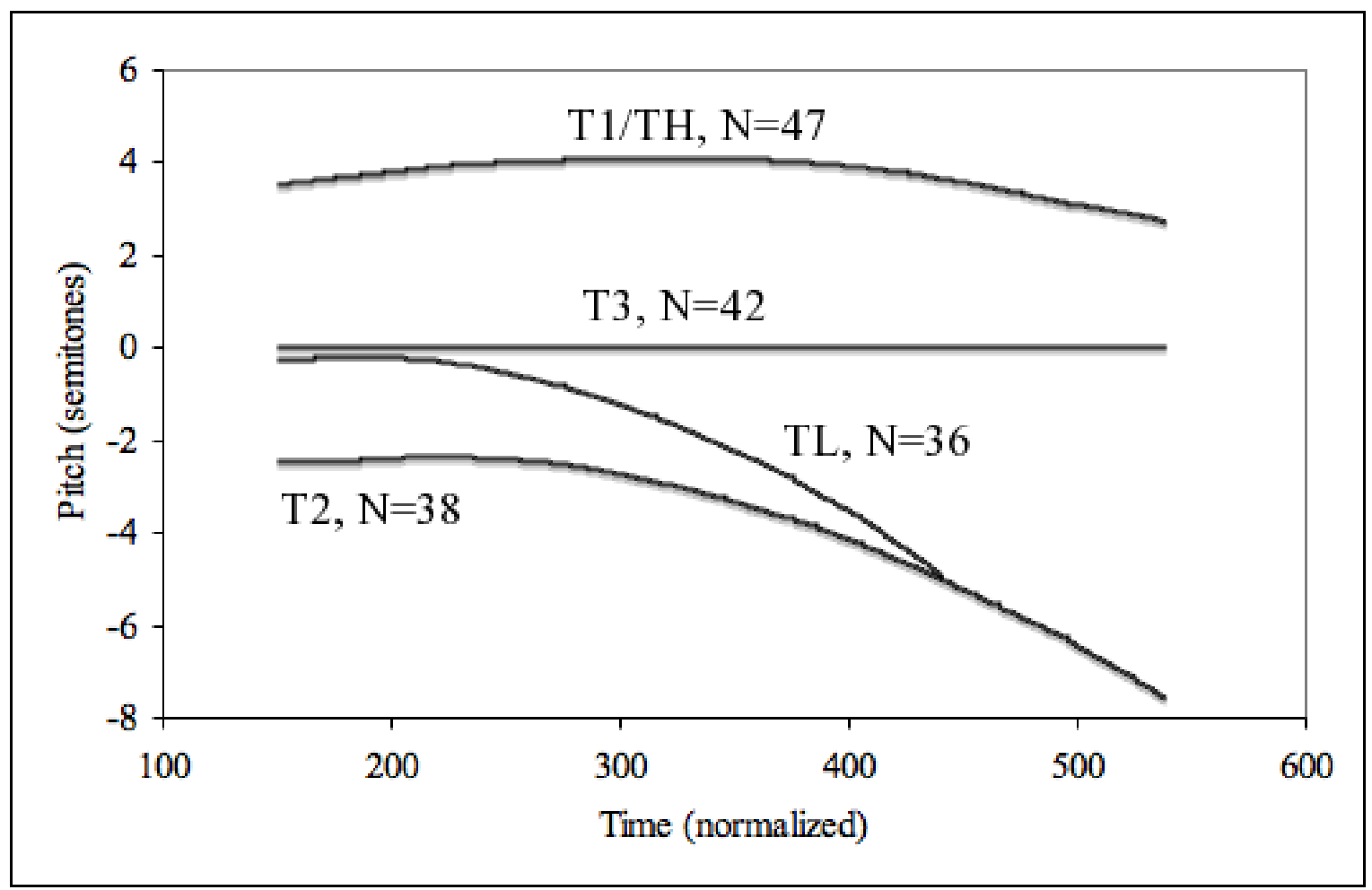

Figure 3: Acoustic tonal analysis of Lawu male speaker in citation form

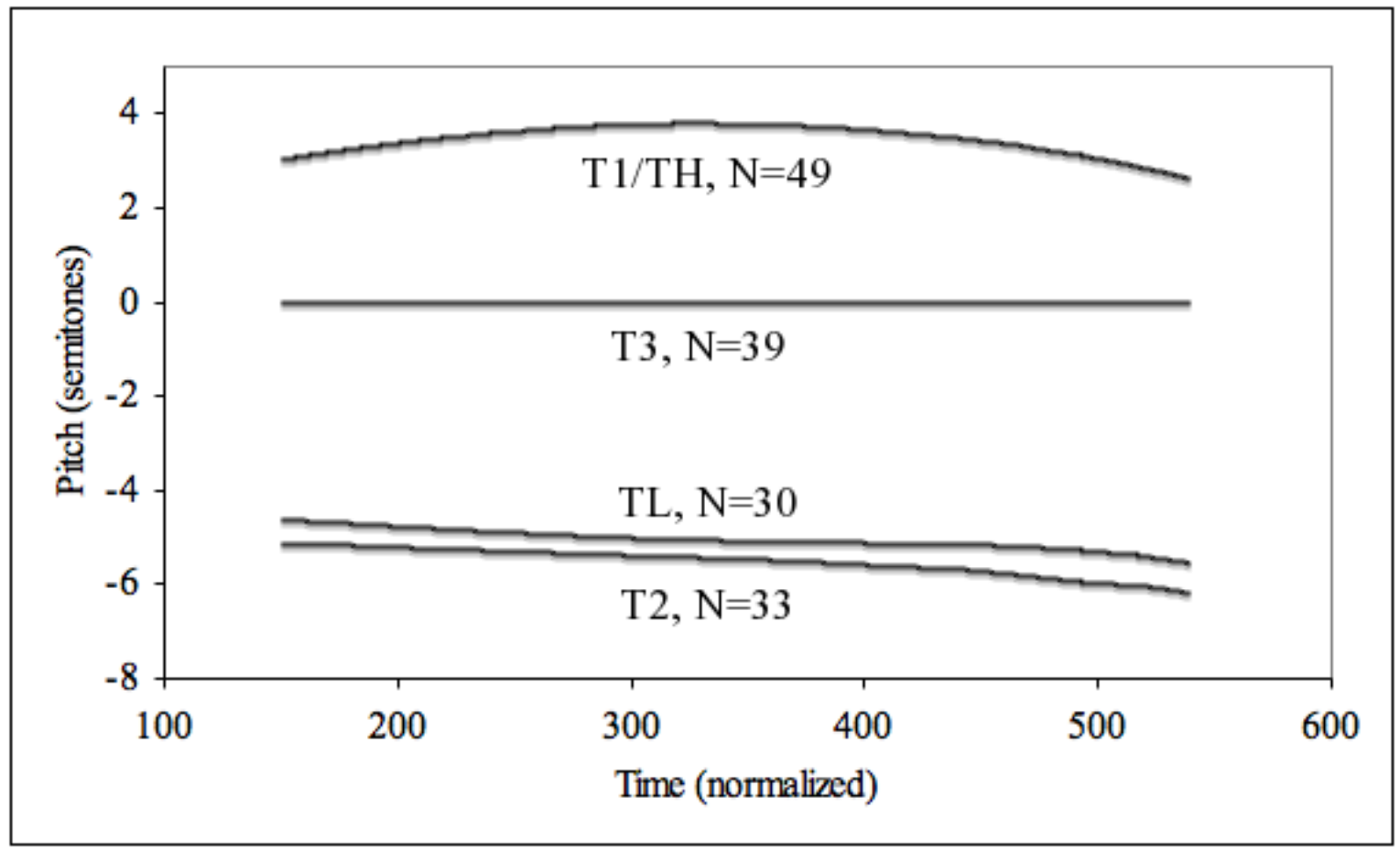

Figure 4: Acoustic tonal analysis of Lawu female speaker in utterance medial form

Table 8 below gives the Lawu tone box, showing the splits and mergers that were conditioned by voicing of the initial consonant. A tone box presents the historic interaction between initial and 
tone, originally developed by Gedney (1972) for Tai languages. Proto-Ngwi *T1 and *TH merged unconditionally to a high level pitch, and then underwent a split wherein voiced initials conditioned the lowering of the high level pitch to a mid level pitch. This resulted in a partial merger with *T3. Syllables with voiceless initials (including preglottalized and voiceless aspirated) remained high. In *T2 (low) and *TL (low and harsh), voiceless initials conditioned a raising of the pitch to mid level, resulting in another partial merger with *T3. Syllables with voiced initials remained low in T2 or became mid falling in TL. After the tone splits and mergers described here, voiced obstruent initials became devoiced, making the mid falling and low pitches contrastive. Lawu tone splits go up or down a prosodic staircase: voiced initials condition the pitch to either step down one level (high > mid) or remain low if the original pitch was low, and voiceless initials condition the pitch to either go up one level (low > mid) or stay high if the original pitch was high.

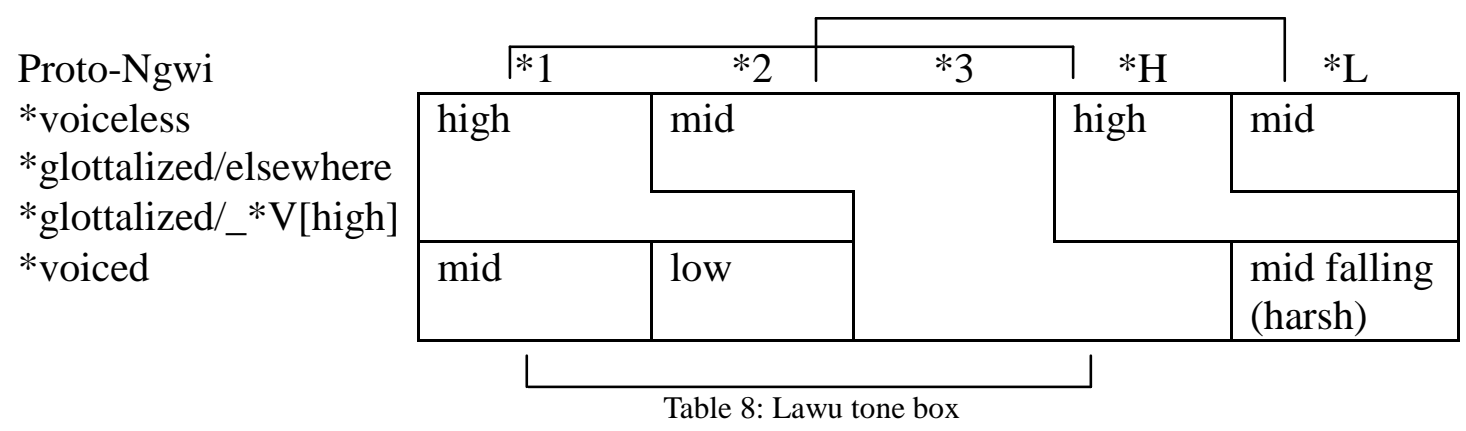

At the Proto-Lawu stage, *T2 and *TL underwent an unusual split in which both the initial consonant and the rhyme played a part. In Proto-Lawu syllables with voiceless unaspirated obstruents or glottalized sonorants, *T2 and *TL pitch reflexes are high when co-occurring with the Proto-Lawu high vowels $*_{\mathrm{i}}$ and $*_{\mathrm{u}}$. Proto-Lawu voiceless unaspirated obstruents and glottalized sonorants descend from Proto-Ngwi glottal-prefixed obstruents and sonorants, as described in Section 4.1. Proto-Lawu high vowels $* \mathrm{i}$ and $*_{\mathrm{u}} \mathrm{descend}$ from various Proto-Ngwi rhymes, summarized in Table 7 . Table 9 gives examples of the conditioning environment that triggered the tone split, and Table 10 gives examples of conditioning that did not (e.g., non-high vowels, non-glottal prefixed initials).

In an additional twist, the Proto-Lawu vowel had to match the place of articulation of the initial in order to trigger the split: after anterior initials (labial and alveolar), the vowel had to be both high and front (i.e., *i) for the split to occur, and after non-anterior initials (e.g., velar), the vowel had to be high and back (i.e., *u). For example, as seen in Table 9, Proto-Lawu *pi ' 'old,' * $\mathrm{ti}^{2}$ 'to pound,' and * $\mathrm{ku}^{2}$ 'head' (from Proto-Ngwi * $\mathrm{p}-\mathrm{kon}^{2}$ ) all show the high level pitch, but not * pay $^{2}$ 'duck' (the split happened before *ay merged to /i/), *?mu² 'to brood,' or *?na ${ }^{2}$ 'ear.' Unfortunately, the wordlist has no examples of *T2 preglottalized sonorants with the correct conditioning for the tone split, but since the split in $* \mathrm{~T} 2$ and $* \mathrm{TL}$ parallel each other in other aspects, I assume that $* \mathrm{~T} 2$ glottalized sonorants also took part. Likewise, in *TL *2li ' 'take off' (Proto-Ngwi reconstruction unknown, compare Proto-Lalo *2li $\underline{i}^{\mathrm{I}}$ ) and ${ }^{*} \mathrm{ku}^{\mathrm{L}}$ 'to bend' became $1 i^{55}$ and $k u^{55}$, respectively. For Proto-Ngwi $* \mathrm{k}-\mathrm{lok}^{\mathrm{L}}$ 'stone' (probably with an epenthetic schwa after the ${ }^{*} \mathrm{k}$ - prefix, $\left.{ }^{*} \mathrm{k} \mathrm{lok}^{\mathrm{I}}\right)$, the vowels in the two syllables likely underwent metathesis while the initial prefix triggered glottalization, i.e., Proto-Ngwi ${ }^{*} k_{\partial l o k}^{\mathrm{L}}>*^{*} \mathrm{k}^{2} \mathrm{Plu}^{\mathrm{L}}>{ }^{\mathrm{L}} \mathrm{ku}^{2} \mathrm{Pli} \underline{\mathrm{i}}^{\mathrm{L}}>l i^{55} \mathrm{ku} u^{55}$. As in $* \mathrm{~T} 2$, the $* \mathrm{TL}$ vowel had to match the place feature of the initial, so neither Proto-Lawu 
*?lu $\underline{u}^{\mathrm{L}}$ 'graze' or *tú ${ }^{\mathrm{L}}$ 'to light a fire' took part in the split. Vowel quality conditioned tone splits are rare, but have been shown to occur in Proto-Lalo (Yang 2010a: 182-186), another Central Ngwi language, and in Lugbara (Andersen 1986).

\begin{tabular}{|l|llllll|}
\cline { 2 - 6 } \multicolumn{1}{c|}{} & old & pound & head & take off & stone & bend \\
\hline Proto-Ngwi & $* 2-\mathrm{bi}^{2}$ & $* 2-\mathrm{di}^{2}$ & $* 2-\mathrm{koy}^{2}$ & $* 2-\mathrm{li}^{\mathrm{L}}$ & $* \mathrm{k}-\mathrm{lok}^{\mathrm{L}}$ & $*$ S-gok \\
Proto-Lawu & $* \mathrm{pi}^{2}$ & $* \mathrm{ti}^{2}$ & $* \mathrm{ku}^{2}$ & $* 21 \underline{i}^{\mathrm{L}}$ & $* \mathrm{ku}^{2} 2 l \underline{i}^{\mathrm{L}}$ & $* \mathrm{ku}^{\mathrm{L}}$ \\
Lawu & $\mathrm{pi}^{55}$ & $\mathrm{ti}^{55}$ & $\mathrm{ku}^{55}$ & $\mathrm{li}^{55}$ & $\mathrm{li}^{55} \mathrm{ku}^{55}$ & $\mathrm{ku}^{55}$ \\
\hline
\end{tabular}

\begin{tabular}{|c|c|c|c|c|c|c|}
\hline & duck & brood & ear & enough & graze & light fire \\
\hline Proto-Ngwi & $* ?-$ bay $^{2}$ & $* ?-\mathrm{mu}^{2}$ & *?-na ${ }^{2}$ & $* \operatorname{lok}^{\mathrm{L}}$ & $* ?-\operatorname{lok}^{\mathrm{L}}$ & $*_{\mathrm{S}-\mathrm{dok}^{\mathrm{L}}}$ \\
\hline Proto-Lawu & $*$ pay $^{2}$ & $* m u^{2}$ & *21a ${ }^{2}$ & $* 1 \underline{u}^{\mathrm{L}}$ & $* 21 \underline{u}^{\mathrm{L}}$ & $* \underline{t u}^{\mathrm{L}}$ \\
\hline Lawu & $\mathrm{pi}^{33}$ & $m u^{21}$ & $1 a^{33}$ & $1 \underline{u}^{31}$ & $1 u^{33}$ & $\mathrm{tu}^{33}$ \\
\hline
\end{tabular}

\section{Lawu's Position within Ngwi}

Lawu is clearly a Ngwi language within the Tibeto-Burman language family, with transparent correspondences to Proto-Ngwi tone categories and many cognates shared with other Ngwi languages. Ngwi has been subgrouped into four main branches: Northern, Southern, Central, and Southeastern (Bradley 2002, Pelkey 2011). Lawu does not share any of the distinctive innovations that characterize Northern, Southern, or Southeastern Ngwi languages, but does show affinity with Central Ngwi through its tone splits in *T1, *T2 and *TL. In Northern Ngwi languages such as Nasu, ${ }^{*} \mathrm{~L}$ became the highest pitch in the tone system (Bradley 1979), a change not seen in Lawu. In Southern Ngwi languages such as Hani and Akha, phonation caused a split in the manner of obstruents, also not seen in Lawu (Thurgood 1982). Other Southern Ngwi languages such as Bisu or Sangkong are very different from Lawu in their development of obstruents, with Proto-Ngwi glottal-prefixed stops becoming aspirated and nasals becoming voiced or prenasalized stops (Matisoff 2003: 17). Nor does Lawu show the development of velaror alveolar-lateral clusters that distinguish Southeastern Ngwi languages (Pelkey 2011).

Instead, Lawu shares the Central Ngwi tendency to split *T1, *T2, and *TL, conditioned by voicing or prefixation of the initial. Table 11 shows a comparative tone box for some Central (C), Southern (S), and Southeastern (SE) Ngwi languages, organized by manner of Proto-Ngwi initial. An underscore below the Chao pitch number represents harsh phonation. Lawu's conditioning of the *T2 split (*voiceless and *2/*s- prefixed initials) overlaps with Lisu's $\left(*^{2} / *^{*}\right.$ s- prefixed) and Lahu's (*voiceless sibilants and $\star^{*} /{ }^{*} s-$ prefixed); Lawu and Lahu may have expanded the original Central Ngwi conditioning environment of *glottal stop and $*_{s}$ prefixation. In the conditioning of the *TL split, Lawu, Lisu and Lahu again share *glottal stop/*s- prefixation, with Lisu and Lahu expanding to include $* \mathrm{C}$ - prefixation $(* \mathrm{C}$ represents Proto-Tibeto-Burman voiced consonantal prefixes $\left.* \mathrm{~b}, *^{\mathrm{d}},{ }^{*} \mathrm{~g}, *^{\mathrm{r}}, * \mathrm{l}\right)$. In contrast, Hani (S) shows no such splits in any tone category. Nisu (SE) shows a glottal-conditioned split in *T1 but not 
elsewhere. Sani (SE) shows tone splits similar to Lisu, but Pelkey (2011) groups Sani as a Southeastern Ngwi language based on other evidence. Although the tone splits suggest affiliation with Central Ngwi, Lawu does not show typical Central Ngwi lexical items such as reflexes of *a na ${ }^{2}$ for 'dog' and *a ?duk ${ }^{\text {I }}$ for 'fire,' described in Bradley 2004a. However, such lexical items are not a requirement for membership in Central Ngwi, as Lahu does not show them either.

Even though Lawu is most likely a Central Ngwi language, it does not clearly belong to the Lisoid (Lisu, Lipo, Lolo), Laloid (Central, Southern, Eka), or Lahoid (Lahu, Kucong) clusters within Central Ngwi. Lawu speakers were previously classified as belonging to the Yi nationality (XPXZ 1993), but are now classified as Lahu. However, there is no linguistic evidence that the Lawu language belongs to the Lahoid cluster of languages (e.g., Kucong, Black and Yellow Lahu). Lawu does not share any distinctive Lahu phonological or lexical innovations, such as *li $>$ [h॰] and others listed in Bradley 2004b. Lawu does not share the distinctive Lalo *T2 split described in Yang 2010a, in which *T2 syllables with glottalized obstruents and the rhyme *-a shifted to *TL. Neither does Lawu share the creation of a high rising tone from a split in $* \mathrm{H}$, as is seen in Lisu and Lamu (Bradley 2004a). At this point, it is unclear which Central Ngwi language Lawu shares the closest relationship with. Further data on other aspects of Lawu phonology and lexicon, as well as morphology and syntax, are needed to confirm Lawu's place within Central Ngwi.

\begin{tabular}{|c|c|c|c|c|c|c|c|}
\hline & Proto-Ngwi Initial Class & $\begin{array}{l}\text { Lawu } \\
\text { (C) }\end{array}$ & $\begin{array}{l}\text { Lisu } \\
\text { (C) }\end{array}$ & $\begin{array}{l}\text { Lahu } \\
\text { (C) }\end{array}$ & $\begin{array}{l}\text { Hani } \\
\text { (S) }\end{array}$ & $\begin{array}{l}\text { Sani } \\
\text { (SE) }\end{array}$ & $\begin{array}{l}\text { Nisu } \\
\text { (SE) }\end{array}$ \\
\hline$* 3$ & all & \multirow[t]{2}{*}{33} & \multirow[t]{3}{*}{33} & 33 & 33 & \multirow[t]{3}{*}{33} & \multirow[t]{3}{*}{21} \\
\hline \multirow[t]{3}{*}{$* 1$} & \multirow{3}{*}{$\begin{array}{l}*_{\text {voiced, }}{ }^{*} \text { C-voiced } \\
*_{\text {voiceless, }}{ }^{*} \text {-voiceless } \\
* \text { ?/s- prefixed }\end{array}$} & & & 21 & \multirow[t]{3}{*}{55} & & \\
\hline & & \multirow[t]{2}{*}{55} & & \multirow[t]{2}{*}{33} & & & \\
\hline & & & 44 & & & 44 & 55 \\
\hline \multirow[t]{4}{*}{$* 2$} & \multirow{4}{*}{$\begin{array}{l}\text { *voiced, }{ }^{*} \text { C-voiced } \\
{ }^{*} \text { voiceless, }{ }^{*} \text { C-voiceless } \\
*^{*} \text { voiceless sibilants } \\
* \text { ?/s- prefixed }\end{array}$} & 21 & \multirow[t]{3}{*}{21} & \multirow[t]{2}{*}{53} & \multirow[t]{4}{*}{21} & \multirow[t]{3}{*}{11} & 33 \\
\hline & & \multirow[t]{4}{*}{33} & & & & & $33 / 21$ \\
\hline & & & & 11 & & & 33 \\
\hline & & & 55 & & & 55 & \\
\hline \multirow[t]{3}{*}{$* \mathrm{H}$} & ${ }^{*}$ voiced, ${ }^{*}$ C-voiced & & \multirow[t]{2}{*}{44} & \multirow[t]{3}{*}{$53 ?$} & \multirow[t]{3}{*}{$\underline{33}$} & \multirow[t]{3}{*}{44} & \multirow[t]{3}{*}{$\underline{33}$} \\
\hline & $* ? / \mathrm{s}-$ prefixed & \multirow[t]{2}{*}{55} & & & & & \\
\hline & ${ }^{*}$ voiceless, ${ }^{*} \mathrm{C}$-voiceless & & 35 & & & & \\
\hline \multirow[t]{5}{*}{$* \mathrm{~L}$} & $*_{\text {voiced }}$ & $\underline{31}$ & \multirow[t]{2}{*}{$\underline{21}$} & \multirow[t]{3}{*}{$21 ?$} & \multirow[t]{5}{*}{$\underline{21}$} & \multirow[t]{3}{*}{11} & \multirow[t]{5}{*}{$\underline{21}$} \\
\hline & $*_{\text {voiceless }}$ & 33 & & & & & \\
\hline & ${ }^{*} \mathrm{C}$-voiceless & & \multirow[t]{3}{*}{55} & & & & \\
\hline & *?/s- prefixed & & & \multirow[t]{2}{*}{35} & & 55 & \\
\hline & ${ }^{*} \mathrm{C}$-voiced & $\underline{31}$ & & & & 11 & \\
\hline
\end{tabular}

Table 11: Tone reflexes in some Ngwi languages 


\section{Conclusion}

Based on diachronic phonology, Lawu is most likely a Central Ngwi language, but has diverged from more well known Central Ngwi languages such as Lisu or Lahu. The Lawu community is in the process of shifting to Southwestern Mandarin and Lawu phonology shows possible influence from contact with SW Mandarin. Although data was gathered from only two Lawu speakers, these preliminary observations lay a foundation for a more comprehensive investigation. Lawu's status as a severely endangered language highlights the urgent need for such investigation, while there are still speakers.

\section{References}

Andersen, Torben. 1986. Tone splitting and vowel quality: Evidence from Lugbara. Studies in African Linguistics 17(1). 55-68.

BDBK. 2011. Baidu Baike: Jiujia xiang [Baidu Encyclopedia: Jiujia District]. http://baike.baidu.com/view/1439397.htm (accessed July 19, 2011).

Boersma, Paul \& David Weenick. 2009. Praat: doing phonetics by computer. Version 5.1.07. http://www.praat.org/. (accessed 17 Jun, 2009).

Bradley, David. 1977. Proto-Loloish tones. In David Bradley (ed.), Papers in Southeast Asian Linguistics No. 5, 1-22. Canberra: Pacific Linguistics.

-----. 1979. Proto-Loloish (Scandinavian Institute of Asian Studies Monograph No. 39). London: Curzon Press.

-----. 2002. The subgrouping of Tibeto-Burman. In Christopher Beckwith \& Henk Blezer (eds.), Medieval Tibeto-Burman languages, vol. 2, 73-112. Leiden: Brill.

----. 2003. Lisu. In Graham Thurgood \& Randy J. LaPolla (eds.), The Sino-Tibetan languages, 222-235. London; New York: Routledge.

-----. 2004a. Endangered Central Ngwi languages of northwestern Yunnan. Paper presented at the 37th International Conference on Sino-Tibetan Languages and Linguistics (ICSTLL), Lund.

-----. 2004b. The Lamu language. Paper presented at the 37th International Conference on SinoTibetan Languages and Linguistics, Lund, Sweden.

Chao Yuanren. 1930. ə 'sistəm əv toun 'letəz. Le Maître Phonétique 30. 24-27.

Edmondson, Jerold \& John H. Esling. 2006. The valves of the throat and their functioning in tone, vocal register and stress: Laryngoscopic case studies. Phonology 23. 157-191.

Gedney, William J. 1972. A checklist for determining tones in Tai dialects. In S.M. Estellie (ed.), Studies in linguistics in honor of George L. Trager, 423-438. The Hague: Mouton.

Ho, Dah-An. 2003. The characteristics of Mandarin dialects. In Graham Thurgood \& Randy J La Polla (eds.), The Sino-Tibetan languages, 126-130. New York: Routledge.

Hombert, Jean-Marie. 1978. Consonant types, vowel quality, and tone. In Victoria A. Fromkin (ed.), Tone: A Linguistic Survey, 77-112. New York: Academic Press.

-----, John J. Ohala \& William G. Ewan. 1979. Phonetic explanations for the development of tones. Language 55(1). 37-58.

Huang, Bufan \& Qingxia Dai, eds. 1992. Zangmian yuzu yuyan cihui [A Tibeto-Burman lexicon]. Beijing: Zhongyang Minzu Daxue Chubanshe.

Lee, Wai-Sum. 2005. The articulatory and acoustical characteristics of the "apical vowels" in Beijing Mandarin. 150th Meeting of the Acoustical Society of America/NOISE-CON 2005. vol. 118, p. 2027. http://hdl.handle.net/10722/54214. 
Matisoff, James A. 1972. The Loloish tonal split revisited (Center for South and Southeast Asia Studies, Research Monograph No. 7). Berkeley: University of California.

-----. 1982 [1973]. The grammar of Lahu (2nd ed., University of California Publications in Linguistics, No. 75). Berkeley: University of California Press.

-----. 2003. Handbook of Proto-Tibeto-Burman: System and philosophy of Sino-Tibetan reconstruction. vol. 135 (UC Publications in Linguistics). Berkeley: University of California Press.

Nolan, Francis. 2003. Intonational equivalence: an experimental evaluation of pitch scales. In Juergen Trouvain \& William J. Barry (eds.), Proceedings of the 15th International Congress of Phonetic Sciences (ICPhS). 771-774. http://www.ling.cam.ac.uk/francis/Nolan\%20Semitones.pdf (accessed 30 Jun 2009).

Pelkey, Jamin R. 1999. Yunnan's myriad Yi: Profiles on the peoples classified as Yi in Yunnan province. Unpublished manuscript.

-----. 2008. The Phula languages in synchronic and diachronic perspective. Melbourne: La Trobe University PhD dissertation.

-----. 2011. Dialectology as Dialectic: Interpreting Phula Variation (Trends in Linguistics: Studies and Monographs). Berlin: Mouton de Gruyter.

Scherer, Klaus R. 1986. Vocal affect expression: A review and a model for future research. Psychological Bulletin 99(2). 143-165. http://www.affectivesciences.org/system/files/1986_Scherer_PsyBull.pdf (accessed Dec 20 2011).

Stanford, James N. 2008. A sociotonetic analysis of Sui dialect contact. Language Variation and Change 20. 409-450.

-----. 2011. Procedure for extracting tones from Praat to txt file, normalizing in R, exporting to Excel. http://www.dartmouth.edu/ jstanford/Procedure-for-extracting-Praat-pitches-to-Exceland-normalizing-in-R.pdf. (accessed Apr 30, 2011).

Sun, Hongkai, ed. 1991. Zangmian yuyin he cihui [Tibeto-Burman Sound Systems and Lexicons]. Beijing: Zhongguo Shehui Kexue Chubanshe.

Thurgood, Graham. 1982. Subgrouping on the basis of shared phonological innovations: A LoloBurmese case study. BLS 8. 251-260.

UNESCO. 2003. Language Vitality and Endangerment. http://www.unesco.org/culture/ich/doc/src/00120-EN.pdf. (accessed Mar 26, 2009).

----. 2009. UNESCO Interactive Atlas of the World's Languages in Danger. http://www.unesco.org/culture/ich/index.php?pg=00139. (accessed Feb 19, 2010).

XPDZ. 1986. Xinping Yizu Daizu zizhixian diming zhi [Geographic place name gazetteer of Xinping county]. Xinping: Renmin Zhengfu.

-----. 1993. Xinping xian zhi [Gazetteer of Xinping county]. 880-02 Di 1 ban. edn. Beijing: Shenghuo, Tushu, Xinzhi San Lian Shudian.

Yang, Cathryn. 2010a. Lalo regional varieties: Phylogeny, dialectometry, and sociolinguistics. Melbourne: $\quad$ La $\quad$ Trobe University $\mathrm{PhD}$ dissertation. http://arrow.latrobe.edu.au:8080/vital/access/HandleResolver/1959.9/153015.

-----. 2010b. Tone change in Lalo. In Yvonne Treis \& Rik De Busser (eds.), Selected Papers from the 2009 Conference of the Australian Linguistic Society. http://www.als.asn.au/proceedings/als2009.html (accessed 30 Apr 2010).

YSX. 2008. Yunnan shuzi xiangcun [Digital Yunnan]. http://www.ynszxc.gov.cn/szxc/ProvincePage/default.aspx. (accessed Feb 23, 2010). 
ZYXZ. 1995. Zhenyuan Yizu Hanizu Lahuzu Zizhixian zhi [Gazetteer of Zhenyuan Yi Hani Lahu autonomous county]. Kunming: Yunnan Renmin Chubanshe.

Author's Contact Information:

Cathryn Yang c/o SIL East Asia

53 Hao, Qing Nian Lu Yan Chang Xian, 18th Floor, Block B, Bin Jiang Da Sha,

Kunming, China 650051

cathryn_yang@sil.org

$+86-13211695460$ 


\section{Appendix A: Lawu Word List}

To listen to the Lawu audio files, please visit the HTML version of this paper here.

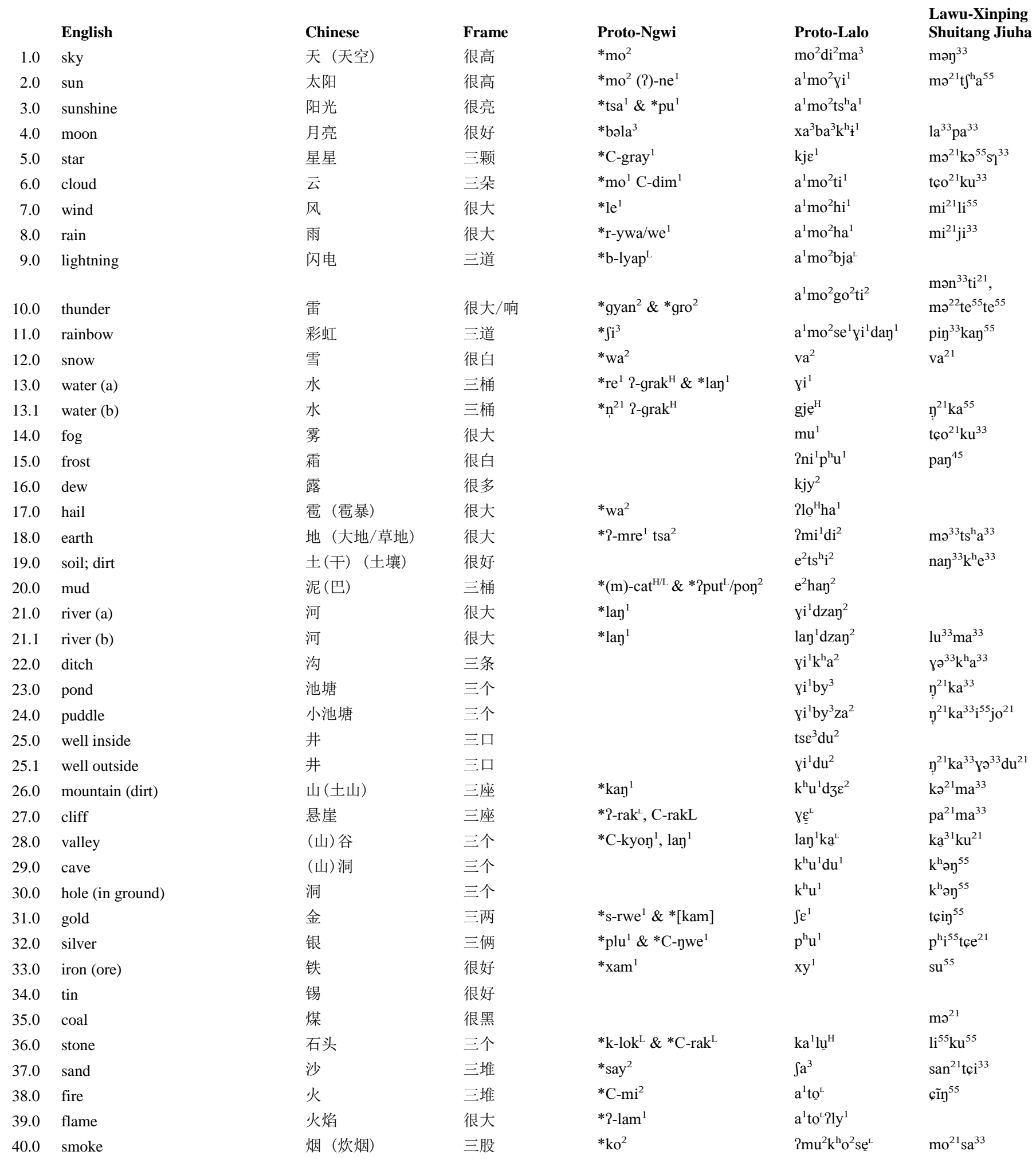




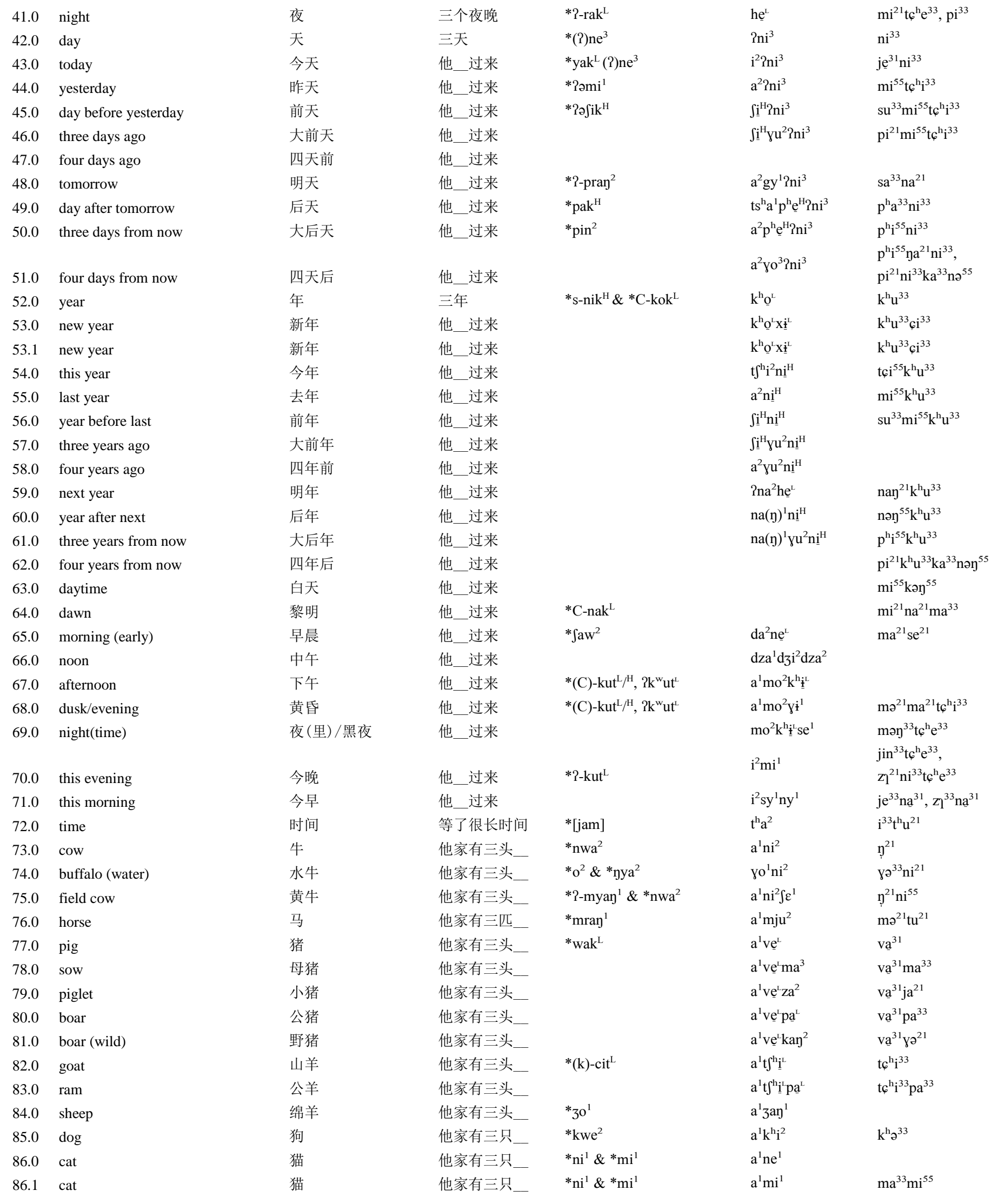




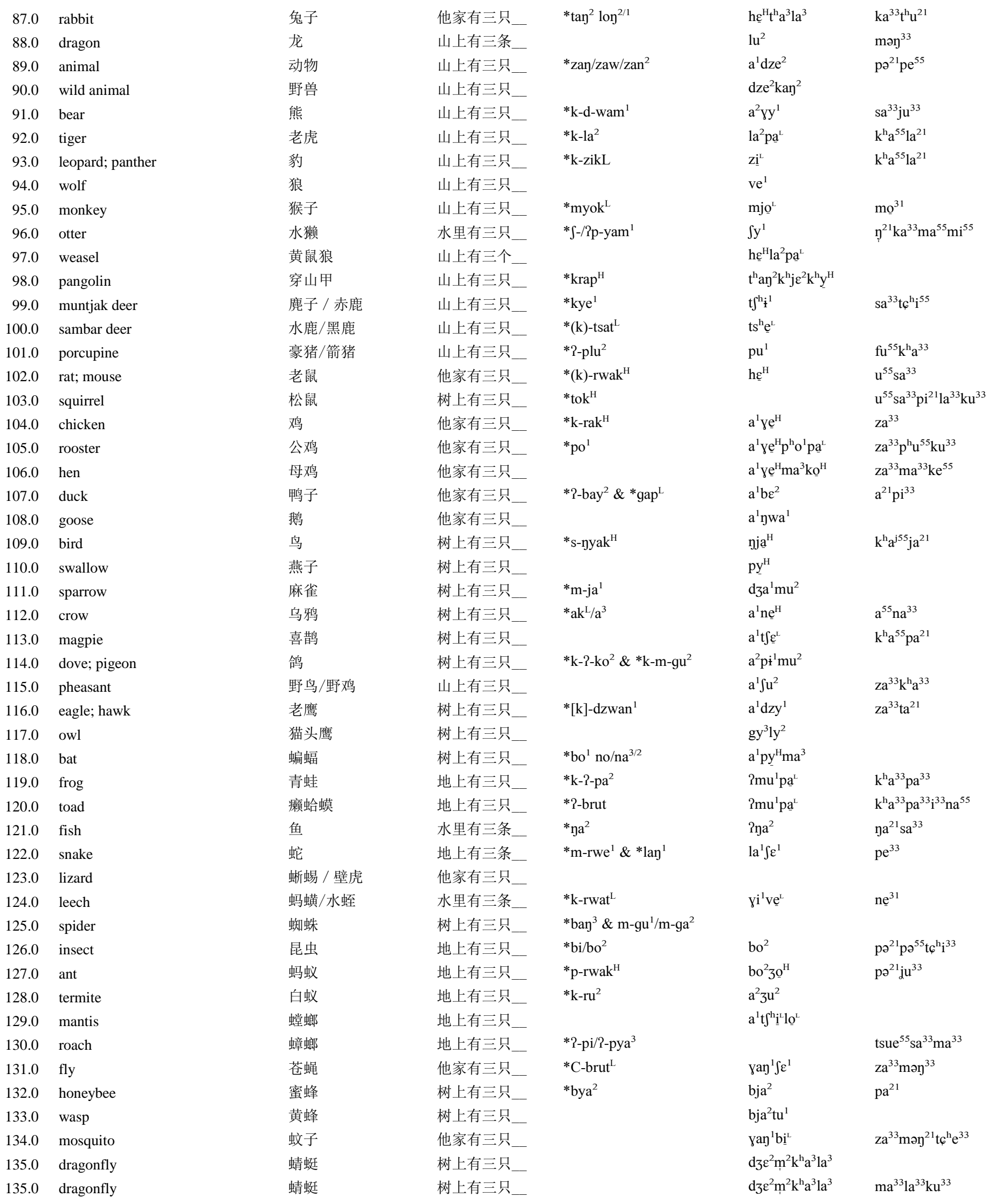




\begin{tabular}{|c|c|c|c|c|c|c|}
\hline 136.0 & butterfly & 蝴蝶 & 树上有三只_ & $* \mathrm{C}-1 \mathrm{u}^{3}$ & $b^{2} 21 u^{3}$ & $\mathrm{a}^{55} \mathrm{pu}^{21} \mathrm{ti}^{55} \mathrm{ti}^{55}$ \\
\hline 137.0 & cricket & 蟋蟀 & 地上有三只_ & & $b \dot{t}^{1} t \int \underline{\varepsilon}^{L}$ & $\mathrm{a}^{33} \operatorname{tson}^{21} \mathrm{tsa}^{33} \mathrm{ts}^{55}$ \\
\hline 138.0 & grasshopper & 蚱蜢 & 地上有三只_ & & $\mathrm{t} \int \varepsilon^{1} \mathrm{pu}^{1}$ & $\begin{array}{l}a^{33} \operatorname{tson}^{21} \operatorname{tsa}^{33} \mathrm{ts}^{55} \mathrm{i} \\
{ }^{33} \text { nəy }^{55}\end{array}$ \\
\hline 139.0 & flea & 跳蚤 & 地上有三只_ & & $\mathrm{k}^{\mathrm{h}} \mathrm{i}^{2} \mathrm{xe}^{1}$ & $\mathrm{k} \partial^{33} \mathrm{ci}^{55}$ \\
\hline 140.0 & louse (clothing) & 䖝子(衣上) & 地上有三只_ & ${ }^{*} \operatorname{xan}^{1}$ & $\mathrm{xe}^{1}$ & $6 \mathrm{c}^{55} \mathrm{tc}^{\mathrm{h}} \mathrm{e}^{33}$ \\
\hline 141.0 & centipede & 蜈蚣 & 地上有三只_ & & $\int a^{1} x e^{1}$ & $\mathrm{p}{\partial^{21}}^{21} \mathrm{i}^{55}$ \\
\hline 142.0 & earthworm & 虾蚓 & 地上有三条_ & $* \mathrm{bu}^{1} /^{2} \mathrm{di}^{1}$ & $a^{1} \mathrm{di}^{1}$ & $\mathrm{pi}^{21} \mathrm{ti}^{55}$ \\
\hline 143.0 & worm & 虫 & 地上有三只_ & $* \mathrm{bu}^{1} /^{2} \mathrm{di}^{1}$ & $b o^{2} \mathrm{di}^{1}$ & \\
\hline 144.0 & caterpillar & 毛虫 & 地上有三条_ & & & \\
\hline 145.0 & maggot & 蛆/蛆虫 & 地上有三条_ & & ho $^{\mathrm{H}}$ & $\mathrm{tc}^{\mathrm{h}} \mathrm{i}^{33} \mathrm{pi}^{55}$ \\
\hline 146.0 & nest & 窝（鸟窝） & 树上有三个_ & & $\mathrm{k}^{\mathrm{h}^{1}}{ }^{1}$ & $\operatorname{pə\eta }^{21}$ \\
\hline 147.0 & egg & 蛋 & 桌上有三个_ & $* u^{3}$ & $\mathrm{fu}^{3}$ & $\mathrm{v}^{33}$ \\
\hline 148.0 & wing & 翅膀 & 三只 & $* \operatorname{do\eta }^{1}$ & $d u^{1} l e^{L}$ & $\operatorname{toy}^{33} \mathrm{na}^{21}$ \\
\hline 149.0 & claw; talon & $\pi$ & 三只 & & $\mathrm{k}^{\mathrm{h}^{1}}{ }^{1} \mathrm{kji}^{3}$ & $\mathrm{k}^{\mathrm{h}} \partial^{55} 6 \mathrm{i}^{33}$ \\
\hline 150.0 & hoof & 蹄 & 三个 & & $\mathrm{k}^{\mathrm{h}^{\mathrm{i}}}{ }^{\mathrm{l}} \underline{y}^{\mathrm{L}}$ & $\mathrm{k}^{\mathrm{h}} \partial^{55}$ \\
\hline 151.0 & horn & 角 & 三个 & $* \mathrm{kro}^{1}$ & $\mathrm{k}^{\mathrm{h}} \mathrm{o}^{1}$ & $\mathrm{k}^{\mathrm{h}} \mathrm{u}^{55}$ \\
\hline 152.0 & tail & 尾巴 & 三条 & ${ }^{*} \mathrm{dan}^{1} 1-\mathrm{mri}^{2}$ & $2 m \varepsilon^{2}$ & $\mathrm{ta}^{33} \mathrm{k}^{\mathrm{h}} \partial \mathrm{y}^{55}$ \\
\hline 153.0 & tusk & 长牙 & 三个 & *?-cway ${ }^{1}$ & $d_{3} \varepsilon^{1}$ & $\mathrm{su}^{55} \mathrm{tci}^{55}$ \\
\hline 154.0 & (cocks)comb & 冠（鸡冠） & 三个 & & $\mathrm{kjo}^{1}$ & $\mathrm{pa}^{21} \mathrm{ta}^{33}$ \\
\hline 155.0 & tree & 树 & 他家有三棵 & $* \operatorname{sik}^{\mathrm{H}} \& * \operatorname{bay}^{2} \& * \mathrm{dzin}^{1}$ & $\mathrm{si}^{\mathrm{H}} \mathrm{dze}{ }^{1}$ & $\mathrm{sl}^{55} \operatorname{tsəy}^{55}$ \\
\hline 156.0 & pine tree & 松树 & 他家有三棵_ & $\begin{array}{l}* \text { C-grip }{ }^{L} \& * \tan ^{2} \& \\
* 1-\operatorname{man}^{2} \& * \text { jun }^{3}\end{array}$ & $\mathrm{t}^{\mathrm{h}} \mathrm{a} \mathrm{y}^{2} \mathrm{dze} \mathrm{e}^{1}$ & $\mathrm{mo}^{21} \mathrm{su}^{33} \mathrm{ts}^{33}$ \\
\hline 157.0 & fir tree & 杉树 & 他家有三棵 & & Pyy $\mathrm{dze}^{1}$ & \\
\hline 158.0 & willow tree & 柳树 & 他家有三棵 & & $\mathrm{yi}^{1} \mathrm{mi}^{2} \mathrm{dze} \mathrm{e}^{1}$ & $\operatorname{lue}^{21} \operatorname{tsəy}^{33}$ \\
\hline 159.0 & bamboo & 竹子 & 他家有三根_ & $* \mathrm{wa}^{2} \& * \mathrm{ma}^{1}$ & $\mathrm{va}^{2}$ & $\mathrm{va}^{21} \mathrm{ma}^{33}$ \\
\hline 160.0 & bamboo shoot & 竹笋 & 他家有三根 & $*_{\text {s-myet }} / \mathrm{L} / \mathrm{H}$ & & $\mathrm{va}^{21} \mathrm{mi}^{21}$ \\
\hline 161.0 & wheat & 小麦 & 他家有三棵 & $\int \mathrm{a}^{3}$ & $\int a^{1}$ & $\mathrm{sa}^{55}$ \\
\hline 162.0 & buckwheat & 荞麦/菾子 & 他家有三棵 & & $\mathrm{ga}^{2}$ & $\mathrm{ko}^{21} \mathrm{ma}^{33} \mathrm{sa}^{33}$ \\
\hline 163.0 & millet & 稷 & 他家有三棵 & & $\operatorname{ts}^{\mathrm{h}} \underline{y}^{\mathrm{L}}$ & \\
\hline 164.0 & barley & 大麦 & 他家有三棵 & $\mathrm{zi}^{1}$ & $\mathrm{zi}^{3}$ & \\
\hline 165.0 & sorghum & 高粱 & 他家有三棵_ & & $2 \mathrm{lu}^{2}$ & $\mathrm{sa}^{55} \mathrm{p}^{\mathrm{h}} \mathrm{a}^{55} \mathrm{tsə \eta}^{33}$ \\
\hline 166.0 & job's tears & 薏荝 & 他家有三棵 & & $\mathrm{na}^{2} \mathrm{ba \eta}^{2} \mathrm{~s} \varepsilon^{2}$ & $\mathrm{lo}^{21} \mathrm{ko}^{21} \mathrm{ts} \mathrm{y}^{33}$ \\
\hline 167.0 & corn & 玉米 & 他家有三棵 & $* \int a^{1} \& * C-k o k^{L}$ & $\int \mathrm{a}^{1} \mathrm{mi}^{2}$ & $\mathrm{sa}^{55} \mathrm{ma}^{33}$ \\
\hline 168.0 & ear of grain & 穗子 & 他家有三棵 & & Pny ${ }^{1}$ & $\mathrm{sa}^{55} \mathrm{vi}^{55}$ \\
\hline 169.0 & peanut & 花生 & 桌上有三个_ & & loan & $\mathrm{mi}^{55} \mathrm{su}^{21} \mathrm{~s}^{33}$ \\
\hline 170.0 & walnut & 核桃 & 桌上有三个 & & $\mathrm{sa}^{2} \mathrm{me}^{1}$ & $\mathrm{ko}^{55} \mathrm{to}^{55} \mathrm{~s}^{33}$ \\
\hline 171.0 & cotton & 棉花 & 他家有三棵 & & $\mathrm{sa}^{1} \mathrm{la}^{2}$ & $\mathrm{sa}^{55} \mathrm{la}^{55}$ \\
\hline 172.0 & ramie & 拦麻 & 他家有三棵 & & $\mathrm{dzi}^{2}$ & \\
\hline 173.0 & bean & 豆子 & 桌上有三个_ & ${ }^{*}$ s-nok ${ }^{\mathrm{H}} \& *$ ?-bay ${ }^{2} / \mathrm{at}^{\mathrm{H}}$ & $n \underline{u}^{\mathrm{H}}$ & $n i^{33} s 1^{33}$ \\
\hline 174.0 & melon & 瓜 & 桌上有三个_ & $* \mathrm{pe}^{2} \beta$ & $\mathrm{p}^{\mathrm{h}} \mathrm{y}^{2}$ & $\mathrm{ta}^{33} \mathrm{k}^{\mathrm{h}} \mathrm{u}^{33}$ \\
\hline 175.0 & gourd & 葫芦 & 桌上有三个_ & $*(P ə)-\mathrm{pu}^{2}$ & $\mathrm{p}^{\mathrm{h}} \mathrm{y}^{2}$ & $a^{55} p^{h} u^{33}$ \\
\hline 176.0 & cucumber & 黄瓜 & 桌上有三个_ & & $\mathrm{sa}^{2} \mathrm{kje}^{2}$ & $\mathrm{~s}^{33} \mathrm{k}^{\mathrm{h}} \mathrm{u}^{33}$ \\
\hline 177.0 & eggplant & 茄子 & 桌上有三个_ & & $\mathrm{ga}^{1} \mathrm{zi}^{3}$ & $\mathrm{ka}^{33} \mathrm{tu}^{21} \mathrm{sl}^{33}$ \\
\hline 178.0 & vegetable & 蔬菜 & 他家有三种_ & & $\operatorname{yan}^{2} t e^{L}$ & $\mathrm{ko}^{21} \mathrm{pi}^{55}$ \\
\hline 179.0 & cabbage greens & 青菜 & 他家有三棵_ & $* \mathrm{Cray}^{2}$ & yan $^{2}$ & $\mathrm{ko}^{31} \mathrm{pi}^{55} \mathrm{nəy}^{55}$ \\
\hline 180.0 & radish & 萝卜 & 桌上有三个_ & & $\operatorname{yan}^{2} t \int^{\mathrm{h}} \mathrm{e}^{1}$ & $\mathrm{ko}^{21} \mathrm{ma}^{33} \mathrm{p}^{\mathrm{h}} \mathrm{u}^{55}$ \\
\hline 181.0 & garlic & 蒜 & 桌上有三个_ & $*_{\operatorname{swan}}{ }^{1 / 2}$ & $\mathrm{k}^{\mathrm{h}} \mathrm{a}^{2} \mathrm{sy}{ }^{1}$ & $\mathrm{k}^{\mathrm{h}} \mathrm{a}^{33} \varphi^{55}$ \\
\hline 182.0 & ginger & 姜 & 桌上有三个_ & & $\mathrm{t}^{\mathrm{h}} \mathrm{a} \mathrm{y}^{2}$ & $\mathrm{ts}^{\mathrm{h}} \mathrm{\partial}^{33}$ \\
\hline 183.0 & galangal & 高良姜（山奈） & 他家有三棵__ & & & $\mathrm{pi}^{21} \mathrm{sl}^{33}$ \\
\hline
\end{tabular}




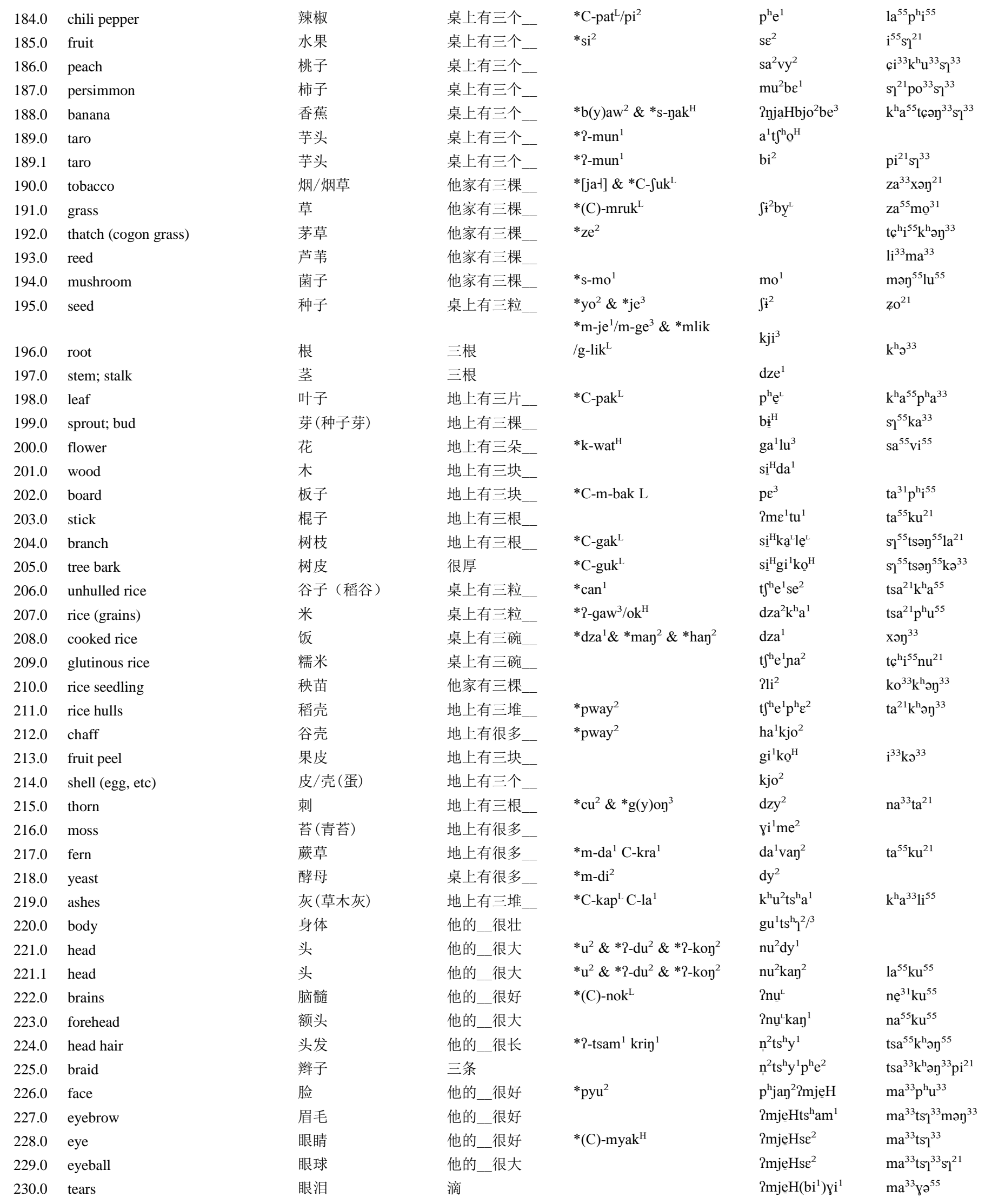




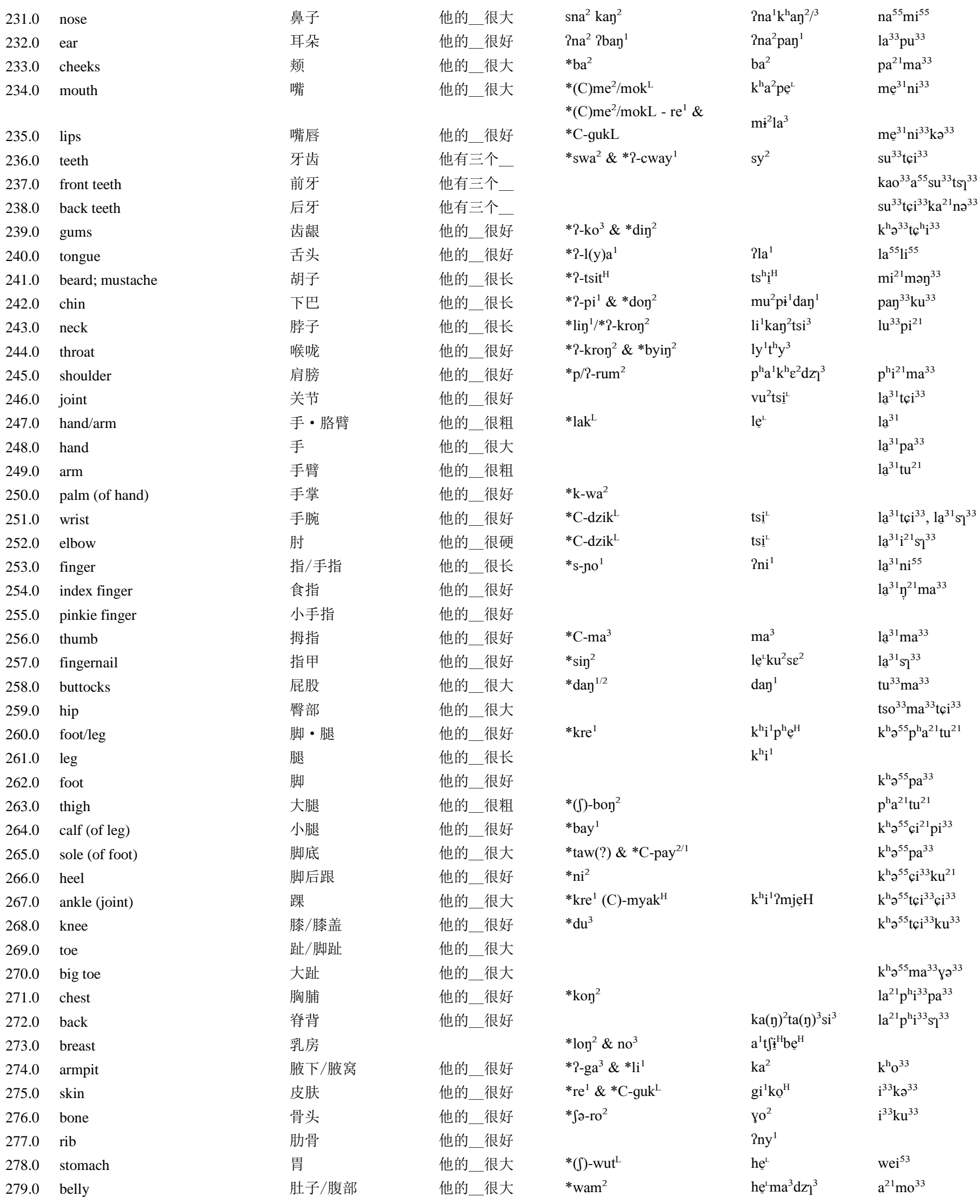




\begin{tabular}{|c|c|c|c|c|c|c|}
\hline 280.0 & navel & 脐（肚脐） & 他的_很大 & $\begin{array}{l}*(\mathrm{C}-\mathrm{k}) \mathrm{yak}^{\mathrm{H}} \& * 2-\mathrm{don}^{1} \& \\
* \mathrm{Ck}^{1}-\mathrm{ru}^{2}\end{array}$ & $t \int^{\mathrm{h}} \underline{e}^{\mathrm{H}} \mathrm{du}{ }^{1 / 2}$ & $\mathrm{k}^{\mathrm{h}} \mathrm{a}^{55} \mathrm{pi}^{33}$ \\
\hline 281.0 & waist & 腰 & 他的_很粗 & $*_{\text {gyaw }}^{2} / \mathrm{ap}^{\mathrm{L}}$ & $\mathrm{d}_{3} \mathrm{O}^{\mathrm{L}}$ & $\mathrm{tso}^{21} \mathrm{ma}^{33}$ \\
\hline 282.0 & kidney & 肾/腰子 & 他的_很好 & *2-bin ${ }^{1}$ & $\mathrm{di}^{1}$ & $\mathrm{tso}^{21} \mathrm{ma}^{33} \mathrm{~s}^{33}$ \\
\hline 283.0 & intestines & 肠子 & 他的_很好 & $* ? u^{1}$ & $h e^{L} v u^{1}$ & $\mathrm{wu}^{33} \mathrm{ti}^{33}$ \\
\hline 284.0 & heart & 心 & 他的_很好 & $*_{n i^{3}}$ & $2 n i^{\mathrm{H}} \mathrm{ma}^{3}$ & $2 \eta^{55} \mathrm{ma}^{33} \mathrm{ci}^{33}$ \\
\hline 285.0 & liver & 肝 & 他的_很好 & $*\left(\int\right)-\sin ^{2}$ & $\mathrm{se}^{2} \mathrm{ts} \varepsilon^{1}$ & $\mathrm{i}^{33} \mathrm{ts}^{\mathrm{h}} \partial \mathrm{y}^{33}$ \\
\hline 286.0 & lung & 肺/肺脏 & 他的_很好 & $*\left(\int\right)-\mathrm{pap}^{\mathrm{L}} \mathrm{tsi}^{2} / \mathrm{tsut}^{\mathrm{H}}$ & $\mathrm{ts}^{\mathrm{h}} \varepsilon^{2} \mathrm{ma}^{3} \mathrm{p}^{\mathrm{h}} \mathrm{u}^{2}$ & $i^{33} p^{h} o^{33}$ \\
\hline 287.0 & bladder? & 膀胱 & 他的_很好 & & $\operatorname{ts}^{h} i^{2} p^{h} u^{2}$ & $\mathrm{p}^{\mathrm{h}} a \eta^{21} \mathrm{~g}^{\mathrm{w}} a \eta^{33}$ \\
\hline 288.0 & gallbladder & 胆/苦胆 & 他的_很好 & & $\mathrm{ki}^{1}$ & $\mathrm{ts}^{\mathrm{h}} \partial \mathrm{y}^{33} \mathrm{p}^{\mathrm{h}} \mathrm{o}^{33}$ \\
\hline 289.0 & bile & 胆汁 & 不好 & $* \mathrm{C}-2-\mathrm{kre}^{1}$ & $\mathrm{ki}^{1} \mathrm{\gamma i}^{1}$ & $\operatorname{ts}^{\mathrm{h}} \partial \mathrm{\gamma}^{33} \mathrm{p}^{\mathrm{h}} \mathrm{o}^{33} \mathrm{i}^{33} \gamma^{33}$ \\
\hline 290.0 & sweat & 汗 & 很多 & *1-krwe ${ }^{2}$ & $\mathrm{kj} \varepsilon^{2}$ & $\mathrm{k} \partial^{33} \mathrm{ts}^{\mathrm{h}} \mathrm{a}^{33}$ \\
\hline 291.0 & blood & 血. & 他的很好 & $* \mathrm{swe}^{2}$ & $\mathrm{si}^{2}$ & $6 i^{33}$ \\
\hline 292.0 & snot & 鼻涕/粘液 & 不好 & $*_{\text {s-napp }}^{\mathrm{L} ;}$ & Pny ${ }^{L}$ & \\
\hline 293.0 & phlegm & 痰 & 不好 & & $\mathrm{ti}^{2} \mathrm{k}^{\mathrm{h}} \mathrm{a}^{2}$ & $\mathrm{tsa}^{33} \mathrm{pi}^{33}$ \\
\hline 294.0 & saliva & 口水 & 不好 & $* \mathrm{kan}^{2}$ & $\mathrm{ti}^{2} \mathrm{\gamma i}^{1}$ & $\mathrm{tsa}^{33} \mathrm{pi}^{33} \mathrm{y}^{33}$ \\
\hline 295.0 & milk & 奶 & 很好 & $* \mathrm{co}^{1} \& \mathrm{no}^{3}$ & $\mathrm{a}^{\mathrm{l}} \mathrm{t} \underline{\underline{\underline{i}}}^{\mathrm{H}}$ & $\operatorname{tso}^{33} \mathrm{pi}^{33} \mathrm{y}^{33}$ \\
\hline 296.0 & excrement & 屎 & 三堆 & $* \mathrm{k}(1) \mathrm{e}^{2}$ & $\mathrm{k}^{\mathrm{h}} \mathrm{ji}^{2}$ & $\operatorname{ts}^{\mathrm{h}} 1^{33}$ \\
\hline 297.0 & urine & 尿 & 不好 & $* \mathrm{~m}-\mathrm{ji}{ }^{2} \& \int \mathrm{i}^{2}$ & $\mathrm{zi}^{2}$ & $\mathrm{n}^{21} \mathrm{ts}^{\mathrm{h}} 1^{55}$ \\
\hline 298.0 & pus & 脓 & 不好 & $*^{m}$-blin ${ }^{1}$ & $\mathrm{bi}^{1}$ & $\mathrm{pi}^{33} \mathrm{tu}^{21}$ \\
\hline 299.0 & sore (wound) & 疮 & 三个 & & $g \varepsilon^{2}$ & \\
\hline 300.0 & body hair; feathers & 毛(翎毛) & & *1-mwe $\mathrm{e}^{3}$ & $\operatorname{ts}^{\mathrm{h}} \mathrm{y}^{1}$ & $\operatorname{mə\eta }^{33}$ \\
\hline 301.0 & penis & 阴茎 & & $*(\mathrm{n})-1 \mathrm{i}^{2}$ & $\mathrm{~h} \varepsilon^{2}$ & $\mathrm{\eta}^{33} \mathrm{ku}^{33}$ \\
\hline 302.0 & vulva & 女阴 & & $*$ bat $^{\mathrm{L}}$ & $\mathrm{tu}^{2}$ & $\mathrm{to}^{21} \mathrm{pi}^{21} \mathrm{tci}^{21}$ \\
\hline 303.0 & anus & 肚门 & & & & $\mathrm{ts}^{\mathrm{h}} \Upsilon^{21} \mathrm{k}^{\mathrm{h}} \partial \eta^{55}$ \\
\hline 304.0 & tendon & 筋/腱 & & $*\left(\int\right)-\mathrm{gru}^{2}$ & $\operatorname{gju}^{2} \mathrm{t} \mathrm{a}^{3}$ & $\mathrm{i}^{33} \mathrm{ku}^{21}$ \\
\hline 305.0 & breath & 呼吸 & & $* \mathrm{C}-\mathrm{sak}^{\mathrm{L}}$ & $\sec ^{1} x a^{1}$ & $\mathrm{i}^{33} \mathrm{sa}^{33} \mathrm{sa}^{33}$ \\
\hline 306.0 & strength & 力气 & & $* \mathrm{ra}^{2} / \mathrm{roy}^{1}$ & $\mathrm{ya}^{2}$ & $\mathrm{i}^{33} \mathrm{sa}^{33}$ \\
\hline 307.0 & person & 人 & 他家有三个_ & $* \operatorname{tsay}^{1}$ & $\operatorname{ts}^{\mathrm{h}} a \mathrm{y}^{1}$ & $\operatorname{ts}^{\mathrm{h}} \mathrm{u}^{55}$ \\
\hline 308.0 & male & 男人 & 他家有三个 & $*$ g-yok ${ }^{\mathrm{L}}$ & $30^{\mathrm{L}}$ & $\mathrm{za}^{21} \mathrm{k}^{\mathrm{h}} \mathrm{a}^{33}$ \\
\hline 309.0 & female & 女人 & 他家有三个一 & $* \mathrm{C}-\mathrm{mi}^{2}$ & $\mathrm{za}^{2} \mathrm{~m} \varepsilon^{2}$ & $\mathrm{mi}^{21} \mathrm{ni}^{33}$ \\
\hline 310.0 & Autonym & （自称） & $\begin{array}{l}\text { 我是数族/ } \\
\text { 腊罗巴人 }\end{array}$ & *Ngwi & $1 a^{2} l \underline{o}^{H} \mathrm{pa}^{\mathrm{L}}$ & $1 a^{21} w^{21}$ \\
\hline 311.0 & Han Chinese & 汉族 & $\begin{array}{l}\text { 他是汉族 } \\
\text { 他们是彝族/ }\end{array}$ & *hyak ${ }^{\mathrm{H},} /$ hay $^{2}$ & $h \underline{e}^{\mathrm{L}} / \underline{h a}^{\mathrm{L}} \mathrm{pa}^{\mathrm{L}}$ & $a^{21} x^{33}$ \\
\hline 312.0 & Yi/Lo & 彝族 & 倮人 & & & $\mathrm{i}^{21} \mathrm{ts}^{\mathrm{h}} \mathrm{u}^{55}$ \\
\hline 313.0 & Bai & 白族 & 他们是 白族 & & & \\
\hline 314.0 & Dai & 傣族 & 他是傣族 & & & $\operatorname{tai}^{21} \operatorname{ts}^{\mathrm{h}} \mathrm{u}^{21} \mathrm{ts}^{\mathrm{h}} \mathrm{u}^{55}$ \\
\hline 315.0 & child & 儿童 & 他家有三个_ & & $a^{1} e^{1} z a^{2}$ & $\mathrm{za}^{21} \mathrm{ni}^{33}$ \\
\hline 316.0 & elderly person & 老人 & 他家有三个_ & & $\operatorname{ts}^{\mathrm{h}} \mathrm{ay}{ }^{1} \mathrm{man}^{2}$ & $\mathrm{ts}^{\mathrm{h}} \mathrm{u}^{55} \mathrm{ma}^{33}$ \\
\hline 317.0 & older man & 老男人 & 他家有三个_ & & $\mathrm{a}^{2} \mathrm{pa}^{1}$ & $\mathrm{ts}^{\mathrm{h}} \mathrm{u}^{55} \mathrm{mu}^{21} \mathrm{ku}^{33}$ \\
\hline 318.0 & older woman & 老女人 & 他家有三个_ & & $a^{2} p^{h} i^{2}$ & $\mathrm{ts}^{\mathrm{h}} \mathrm{u}^{55} \mathrm{ma}^{33}$ \\
\hline 319.0 & boy & 青年男人 & 他家有三个_ & & $\mathrm{su}^{1} l \underline{e}^{\mathrm{L}} \mathrm{pa}^{\mathrm{L}}$ & $\mathrm{za}^{21} \mathrm{k}^{\mathrm{h}} \mathrm{a}^{33}$ \\
\hline 320.0 & girl & 青年女人 & 他家有三个_ & & $\mathrm{su}^{1} \underline{e}^{\mathrm{L}} \mathrm{ma}^{3}$ & $\mathrm{za}^{21} \mathrm{mi}^{21}$ \\
\hline 321.0 & friend & 朋友 & 他有三个__ & ${ }^{*} \mathrm{kyan}^{2}$ & & $\mathrm{za}^{21} \mathrm{ts}^{\mathrm{h}} \mathrm{u}^{21}$ \\
\hline 322.0 & enemy & 敌人 & 他有三个_ & & & $\operatorname{ts}^{\mathrm{h}} \mathrm{u}^{55} \mathrm{k}^{\mathrm{h}} \mathrm{u}^{33}$ \\
\hline 323.0 & host & 主人 & 他有三个_ & & $\mathrm{si}^{2} \mathrm{p}^{\mathrm{h}} \mathrm{a}^{2}$ & $i^{55} p^{h} a i^{33}$ \\
\hline 324.0 & guest & 客人 & 他有三个__ & & $\mathrm{se}^{1} \mathrm{ye}^{3}$ & $\operatorname{ta}^{21} \mathrm{ni}^{33}$ \\
\hline 325.0 & lame person & 瘸子/跛子 & 村里有三个_ & & $\mathrm{k}^{\mathrm{h}} \mathrm{i}^{1} \mathrm{pe}^{3}$ & $\mathrm{k}^{\mathrm{h}} \mathrm{\rho}^{55} \mathrm{tu}^{33}$ \\
\hline 326.0 & official & 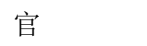 & 村里有三个_ & & $\mathrm{dzi}^{2} / 3$ & $\mathrm{tsu}^{21} \mathrm{ma}^{33}$ \\
\hline 327.0 & high official & 大官 & 村里有三个_ & & $\mathrm{dzi}^{2} / 3$ & \\
\hline
\end{tabular}




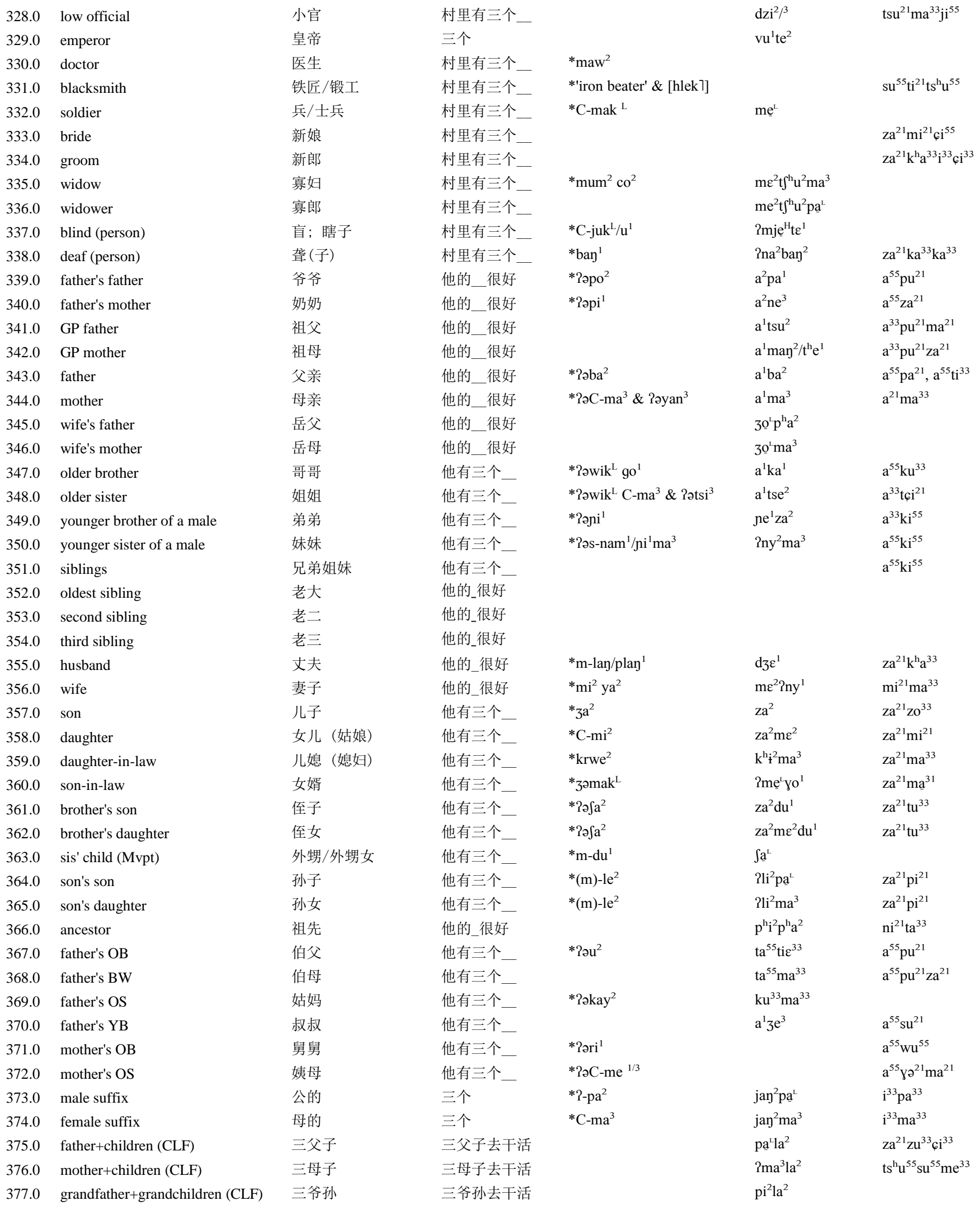




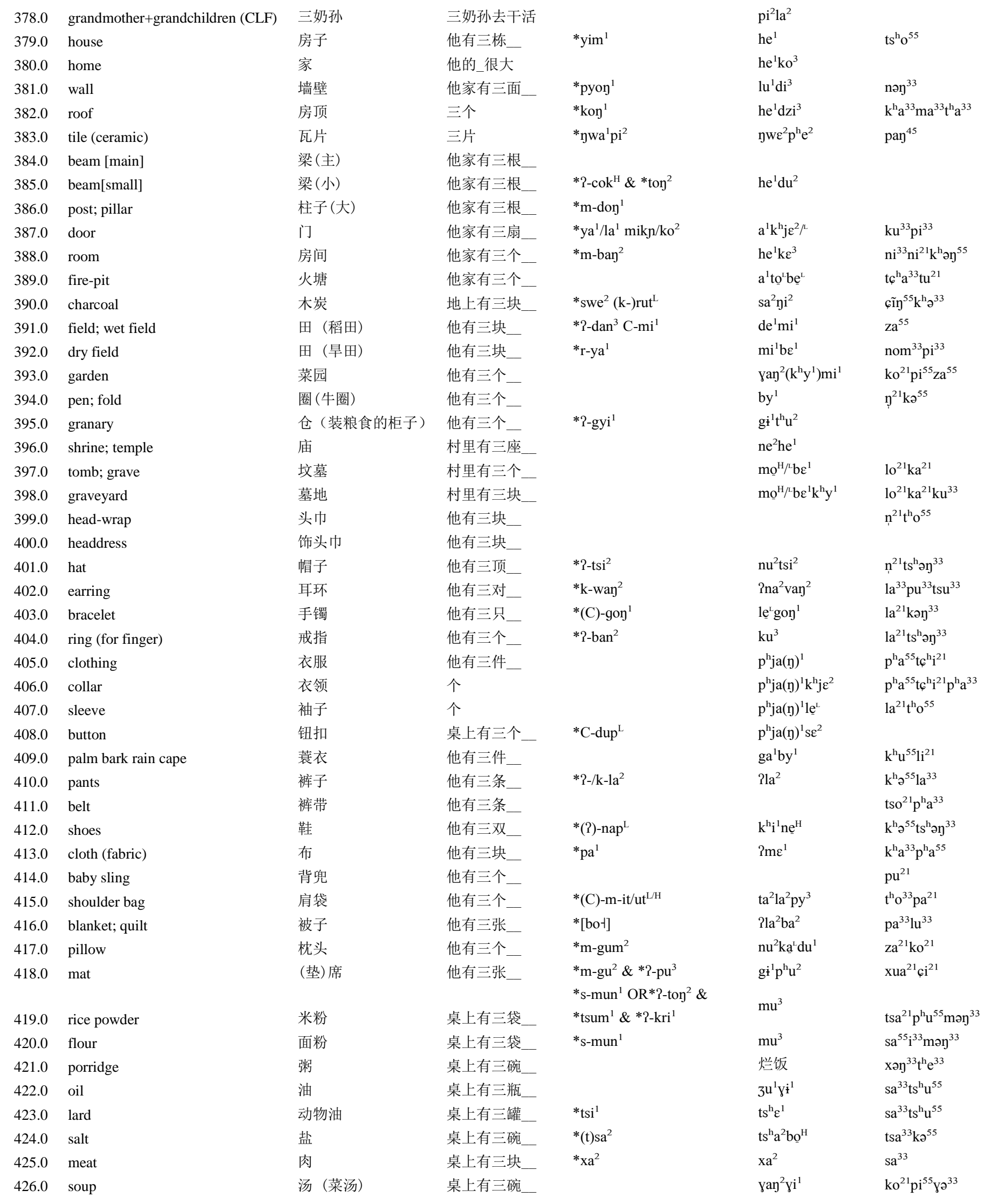




\begin{tabular}{|c|c|c|c|c|c|c|}
\hline 427.0 & liquor & 酒 & 桌上有三碗 & $\mathrm{nji}^{1}$ & $d 3^{1}$ & $\mathrm{t} 6 \mathrm{i}^{33} \mathrm{pa}^{21}$ \\
\hline 428.0 & tea & 茶 (茶水) & 桌上有三杯_ & $* 1 a^{1}$ & $1 a^{2}$ & \\
\hline 429.0 & sugar & 糖 & 桌上有三个 & & $\int a^{1} b a^{2}$ & $\mathrm{pi}^{55} \mathrm{tsu}^{55} \mathrm{ku}^{33}$ \\
\hline 430.0 & jaggery & 红糖 & 桌上有三只_ & & $\int \mathrm{a}^{1} \mathrm{da}^{2}\left(2 \mathrm{ni}^{1}\right)$ & \\
\hline 431.0 & saw & 锯子 & 他有三把_ & $*_{s-1 w a^{3}}$ & yi $\underline{1}^{\mathrm{t} s y^{3}}$ & $\operatorname{ts}^{\mathrm{h}} \mathrm{o}^{55} \mathrm{tci}^{33}$ \\
\hline 432.0 & knife & 刀 & 桌上有三把 & $* \tan ^{3} \& * 2-\operatorname{mi}(a)^{1} * \& \operatorname{ta}^{2}$ & $\mathrm{a}^{1} \mathrm{t}^{\mathrm{h}} \mathrm{a}^{2}$ & $\mathrm{p}^{\mathrm{h}} \mathrm{in}^{33}$ \\
\hline 433.0 & kitchen knife & 菜刀 & 桌上有三把 & & $a^{1} t^{h} a^{2} b a^{2}$ & $\mathrm{pi}^{55} \mathrm{to}^{55}$ \\
\hline 434.0 & pointed knife & 尖刀 & 桌上有三把 & & $a^{1} t^{h} a^{2} l e^{L}$ & $\mathrm{p}^{\mathrm{h}} \tilde{\mathrm{in}} \mathrm{j}^{33} \mathrm{tci}^{33} \mathrm{ja}^{21}$ \\
\hline 435.0 & sickle & 镰刀 & 他有三把_ & $*_{\mathrm{C}}-\mathrm{gap}{ }^{\mathrm{L}}$ & $n^{2} \operatorname{ts}^{h^{h}} \underline{O}^{H}$ & $1 \mathrm{i}^{55} \mathrm{tu}^{55}$ \\
\hline 436.0 & hatchet & 斧头 & 他有三把 & $* 2-\operatorname{cin}^{2}$ & $\mathrm{a}^{1} \mathrm{ts}^{\mathrm{h}} \underline{\underline{o}}^{\mathrm{H}}$ & $\mathrm{pa}^{21} \mathrm{t}^{\mathrm{h}} \partial \mathrm{y}^{55}$ \\
\hline 437.0 & hoe (large) & 锄头 & 他有三把 & $*$ ?-guk ${ }^{\mathrm{H}}$ & $\mathrm{tse}^{2}$ & $\mathrm{t} 6 \mathrm{i}^{33} \mathrm{tu}^{21}$ \\
\hline 438.0 & plow & 犁 & 他有三张 & & $\mathrm{si}^{\mathrm{H}} \mathrm{gog}^{\mathrm{L}}$ & $t^{\mathrm{h}} a^{55} 1 i^{55}$ \\
\hline 439.0 & yoke & 牛轭 & 他有三根 & & $1 \mathrm{a}^{2} \mathrm{e}^{\mathrm{H}}$ & $\mathrm{n}^{21} \mathrm{pa}^{33} \mathrm{la}^{33}$ \\
\hline 440.0 & thing & 东西 & 桌上有三种_ & ${ }^{*} \mathrm{C}-\mathrm{m}(\mathrm{y}) \mathrm{u}^{2} / \beta \& *[\mathrm{cən}]$ & $\mathrm{d} z \mathrm{e}^{1} \mathrm{ku}^{1}$ & $\mathrm{mu}^{21} \mathrm{ja}^{21}$ \\
\hline 441.0 & loom & 织布机 & 他有三台_ & $*(\mathrm{~g})-\mathrm{rak}^{\mathrm{L}}$ & & \\
\hline 442.0 & needle & 针 & 桌上有三根 & $*_{\text {g-rap }}{ }^{\mathrm{L}}$ & $\gamma \mathrm{y}^{\mathrm{L}}$ & $\mathrm{ci}^{33} \mathrm{ko}^{31}$ \\
\hline 443.0 & awl & 雉子 & 他有三把_ & & & \\
\hline 444.0 & thread & 线（缝衣用的） & 桌上有三根 & Ptsam ${ }^{1}$ & $\mathrm{k}^{\mathrm{h}^{1}}{ }^{1}$ & $\operatorname{koy}^{33} \mathrm{tsa}^{55}$ \\
\hline 445.0 & ball (of thread) & 线球 & 桌上有三个 & & & $\mathrm{koy}^{33} \mathrm{tsa}^{55} \mathrm{zo}^{33}$ \\
\hline 446.0 & rope; string & 绳子 & 他有三条_ & & & $\eta_{1}^{21} \operatorname{tsa}^{55}$ \\
\hline 447.0 & chain & 链子 & 他有三条 & $*$ ?-cak ${ }^{\mathrm{H}}$ & $\int \underline{0}^{\mathrm{H}}$ & $\mathrm{su}^{55} \mathrm{tsa}^{55}$ \\
\hline 448.0 & whip (horse whip) & 鞭子（马鞭子） & 他有三根 & & $\mathrm{la}^{2} \mathrm{k}^{\mathrm{h}} \mathrm{o}^{\mathrm{H}}$ & $\mathrm{ta}^{33} \mathrm{ku}^{21}$ \\
\hline 449.0 & winnowing basket & 簸箕（箕米用） & 他有三个 & $*$ ?-wa ${ }^{1}$ & $2 \mathrm{va}^{1}$ & $\mathrm{pa}^{33} \mathrm{ma}^{33}$ \\
\hline 450.0 & bamboo sieve; sifter (fine) & 笁子 (细的) & 他有三张 & & $2 \mathrm{va}^{1} \mathrm{kit}^{1}$ & $\mathrm{ka}^{21} \mathrm{k}^{55}$ \\
\hline 451.0 & whetstone & 磨刀石 & 他有三块 & & $a^{1} t^{h} a^{2} s \varepsilon^{2} k a^{1} l u^{H}$ & $\mathrm{p}^{\mathrm{h}} \mathrm{in}^{33} \mathrm{~s}^{33}$ \\
\hline 452.0 & millstone & 石磨 & 他有三块 & & $\mathrm{ni}^{\mathrm{L}}$ & $\mathrm{l}^{\mathrm{j}} \mathrm{u}^{45}$ \\
\hline 453.0 & hammer & 锤子 & 他有三把 & ${ }^{*} \mathrm{C}-\mathrm{tu}^{1} \& * \mathrm{kay}^{1}$ & & $\mathrm{ta}^{33} \mathrm{t}^{\mathrm{h}} \mathrm{u}^{55} \mathrm{~s} 1^{33}$ \\
\hline 454.0 & chisel & 丵子 & 他有三把 & & & $\operatorname{ts}^{2} y^{21}$ \\
\hline 455.0 & rice huller & 碓 & 他有三个_ & & $\mathrm{ts}^{\mathrm{h}} \mathrm{y}^{1}$ & tso $^{55} \mathrm{mi}^{55} \mathrm{ku}^{33}$ \\
\hline 456.0 & rice pounder & 米臼 & 他有三个_ & & & $\mathrm{ta}^{33} \mathrm{t}^{\mathrm{h}} \mathrm{u}^{55} \mathrm{ku}^{33}$ \\
\hline 457.0 & mortar & 臼 & 他有三个_ & & & $\mathrm{tsa}^{21} \mathrm{k}^{33} \mathrm{k}^{\mathrm{h}} \partial^{21} \mathrm{tu}^{33}$ \\
\hline 458.0 & pestle & 杵 & 他有三个_ & & & $\mathrm{ta}^{33} \mathrm{t}^{\mathrm{h}} \mathrm{u}^{55} \mathrm{~s} 1^{33}$ \\
\hline 459.0 & medicine; herbal medicine & 药 & 桌上有三种_ & ${ }^{*} \mathrm{C}-\mathrm{nak}^{\mathrm{H}} \mathrm{tsip}^{\mathrm{L} / \mathrm{tse}^{2}}$ & $\mathrm{n} \varepsilon / \mathrm{e}^{\mathrm{H}} \mathrm{ts}^{\mathrm{h}^{2}}{ }^{2}$ & $\mathrm{k}^{\mathrm{h}} \partial^{33} \mathrm{tci}^{33}$ \\
\hline & & & & ${ }^{*} \mathrm{C}-\mathrm{krak}^{\mathrm{L}} \&$ & & \\
\hline 460.0 & bamboo basket & 箩筐（背东西用） & 他有三只_ & $* \mathrm{ka}^{2}+* \mathrm{~m}-$ gyap ${ }^{\mathrm{L}}$ & & 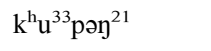 \\
\hline 461.0 & broom & 扫帚 & 他有三把_ & $* \mathrm{sut}^{\mathrm{H}}$ & $g \dot{1}^{1} \mathrm{Si}^{\mathrm{H}}$ & $\mathrm{sa}^{55} \mathrm{p}^{\mathrm{h}} \mathrm{a}^{55}$ \\
\hline 462.0 & pot; pan; wok & 锅（炒菜的） & 他有三个_ & $* ? o^{2}$ & $a^{2} t \int^{h} \varepsilon^{1}$ & $\mathrm{mi}^{21} \mathrm{k}^{\mathrm{h}} \mathrm{u}^{33}$ \\
\hline 463.0 & tub; bucket & 桶 & 他有三个_ & & $\gamma \dot{i}^{1} t^{\mathrm{h}} u^{2}$ & \\
\hline 464.0 & barrel, ceramic & 土罐 & 他有三个_ & & $2 n u^{1}$ & $\mathrm{ts}\rceil^{21} \mathrm{pa}^{21} \mathrm{ko \eta}^{55}$ \\
\hline 465.0 & washbasin & 盆 & 他有三个_ & & $\operatorname{lag}^{2}$ & $\mathrm{k}^{\mathrm{h}} \mathrm{\partial}^{33} \mathrm{tu}^{21}$ \\
\hline 466.0 & bag; sack & 袋子 & 他有三个_ & & $1 a^{1} 21 \underline{i}^{\mathrm{L}}$ & \\
\hline 467.0 & comb (regular) & 梳子 & 他有三把 & ${ }^{*} \mathrm{gwi}^{2}$ & $\mathrm{~m}^{2} \mathrm{pji}^{2}$ & $\mathrm{mu}^{21} \mathrm{su}^{33}$ \\
\hline 468.0 & fine toothed comb & 细密梳子 & 他有三把 & & $\mathrm{m}^{2} \mathrm{pji}^{2} \mathrm{dzi}{ }^{1}$ & $\mathrm{pi}^{55} \mathrm{ts}^{21}$ \\
\hline 469.0 & bowl & 碗 & 桌上有三个_ & & $\mathrm{a}^{1} \mathrm{kj} \varepsilon^{2}$ & $\mathrm{k}^{\mathrm{h}} \mathrm{u}^{33}$ \\
\hline 470.0 & small bowl & 小碗 & 桌上有三个_ & & $\mathrm{a}^{1} \mathrm{kje}^{2} \mathrm{za}^{2}$ & $\mathrm{k}^{\mathrm{h}} \mathrm{u}^{33} \mathrm{ja}^{21}$ \\
\hline 471.0 & large bowl & 大碗 & 桌上有三个 & & & $\mathrm{k}^{\mathrm{h}} \mathrm{u}^{33} \mathrm{t}^{\mathrm{h}} \mathrm{u}^{33} \mathrm{ma}^{33}$ \\
\hline 472.0 & chopsticks & 筷子 & 桌上有三双 & $* \mathrm{~d} / \mathrm{gy} / \mathrm{j} / \mathrm{yu}^{1 / 3}$ & $a^{1} d z u^{3}$ & $\operatorname{tc} \mathrm{i}^{33} \mathrm{ta}^{55}$ \\
\hline 473.0 & bed & 床 & 他有三张_ & & $\mathrm{gy}^{2}$ & $\mathrm{zo}^{21} \mathrm{k}^{\mathrm{h}} \mathrm{o}^{33}$ \\
\hline 474.0 & ladder & 梯子 & 他有三架_ & $*$ dzam $^{3} \& * \mathrm{~m}-\mathrm{gu}^{1} / 2$ & $d e^{\mathrm{H}} \mathrm{go}^{\mathrm{L}}$ & $\mathrm{ko}^{33} \mathrm{tsu}^{33}$ \\
\hline 475.0 & firewood & 柴 & 地上有三根 & & $\mathrm{si}^{\mathrm{H}}$ & $\operatorname{cin}^{55}$ \\
\hline
\end{tabular}




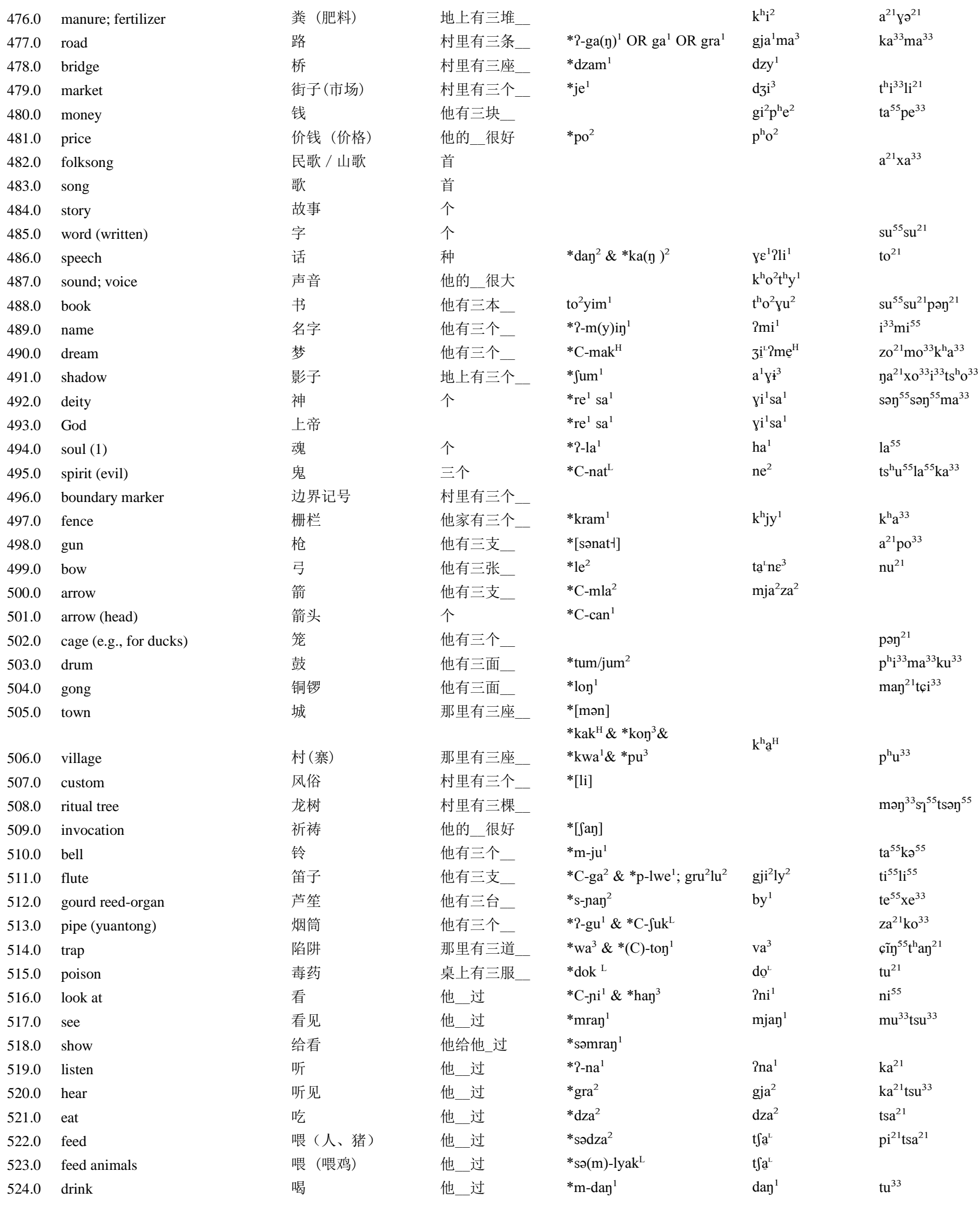




\begin{tabular}{|c|c|c|c|c|c|c|}
\hline 525.0 & give to drink & 给喝 & 他给他_过 & $*_{\text {səm-day }}^{1}$ & $\tan ^{3}$ & \\
\hline 526.0 & bite & 咬 & 他_过 & ${ }^{*} \mathrm{C}$-tsat ${ }^{\mathrm{L}} \& * \mathrm{C}-\mathrm{kuk}^{\mathrm{L}}$ & $\mathrm{k}^{\mathrm{h}} \underline{\underline{o}}^{\mathrm{L}}$ & $t 6^{\mathrm{h}} \mathrm{e}^{33}$ \\
\hline 527.0 & chew & 嚼 & 他_过 & $*(\mathrm{~g})$ wa $^{2} \& *$ m-bay ${ }^{2}$ & $\mathrm{ga}^{2}$ & $\mathrm{k}^{\mathrm{h}} \mathrm{o}^{33}$ \\
\hline 528.0 & lick & 舔 & 他_过 & $* \mathrm{~m}-\mathrm{lyak}^{\mathrm{L}}$ & $1 \underline{\varepsilon}^{L}$ & $1 e^{33}$ \\
\hline 529.0 & savor & 含 & 他_过 & & $\mathrm{my}^{1}$ & $\operatorname{mon}^{33} 1 a^{45}$ \\
\hline 530.0 & swallow & 咽 & 他_过 & $* \operatorname{myo}(\mathrm{k})^{1 / 1} \mathrm{~L} \int$ & gjo $^{1}$ & jĩn $\eta^{55}$ \\
\hline 531.0 & spit & 吐 (吐口水) & 他_过 & & $\mathrm{p}^{\mathrm{h} \underline{\underline{i}}^{\mathrm{L}}}$ & $\mathrm{tsa}^{21} \mathrm{pi}^{33} \mathrm{pi}^{33}$ \\
\hline 532.0 & vomit & 呕吐 & 他_过 & $* \mathrm{C}-\mathrm{pat}^{\mathrm{L}}$ & $\mathrm{p}^{\mathrm{h}} \mathrm{e}^{\mathrm{L}}$ & $m^{21} p^{h} i^{33} p^{h} i^{33}$ \\
\hline 533.0 & suck & 吸 & 他_过 & $* \mathrm{C}$-cut ${ }^{\mathrm{L}}$ & & $\mathrm{s}^{21}$ \\
\hline 534.0 & blow (on) & 吹（吹火） & 他_过 & $*_{\mathrm{s}-\mathrm{mut}}{ }^{\mathrm{H}}$ & $2 m y^{\mathrm{H}}$ & $\mathrm{mi}^{33}$ \\
\hline 535.0 & say & 说 & 他_过 & $* 2 \mathrm{uk}^{\mathrm{H}}$ & $\mathrm{be}^{\mathrm{H}}$ & $\mathrm{ko}^{33}$ \\
\hline 536.0 & speak & 讲 & 他_过 & $*$ yaw $^{3} \& *$ dze $^{2}$ & $\mathrm{t}^{\mathrm{h}} \mathrm{y}^{1}$ & \\
\hline 537.0 & tell & 告诉 & 他_过 & & $\mathrm{be}^{\mathrm{H}} \mathrm{gu}^{2}$ & $\mathrm{ko}^{33} \mathrm{væ}^{21}$ \\
\hline 538.0 & call; be called & 叫 & 他_过 & $* \mathrm{ku} / \mathrm{kaw}^{1}$ & $\mathrm{ku}^{1}$ & $\mathrm{ku}^{33}$ \\
\hline 539.0 & ask & 问 & 他_过 & & $\mathrm{Pna}^{1}$ & $\mathrm{na}^{55} \mathrm{ni}^{55}$ \\
\hline 540.0 & answer & 答（回答） & 他_过 & & $\mathrm{po}^{\mathrm{H}}$ & \\
\hline 541.0 & send for; request & 请 & 他_过 & & $\mathrm{ts}^{\mathrm{h}} \varepsilon^{3}$ & $\mathrm{ts}^{\mathrm{h}} \partial \mathrm{\eta}^{33}$ \\
\hline 542.0 & smell & 闻（嗅） & 他_过 & & $n y^{2}$ & $\mathrm{ni}^{55}$ \\
\hline 543.0 & touch; feel; stroke & 摸（摸摸刀口） & 他_过 & $*$ to $^{2}$ & $\mathrm{mo}^{\mathrm{H}}$ & $\mathrm{so}^{55}$ \\
\hline 544.0 & take & 拿（拿书） & 他_过 & $* \mathrm{yu}^{1}$ & $\mathrm{vu}^{1}$ & $\mathrm{vi}^{33}$ \\
\hline 545.0 & grasp; grip & 握 (握刀把) & 他_过 & $* n^{2}$ & & $\mathrm{so}^{55}$ \\
\hline 546.0 & grab & 抓住 & 他_过 & $*_{\mathrm{s}-\mathrm{mi}}{ }^{1}$ & & $\mathrm{ka}^{55}$ \\
\hline 547.0 & pick (e.g., fruit) & 摘（摘果子） & 他_过 & $* \mathrm{C}-\mathrm{xak}^{\mathrm{L}}$ & $\mathrm{ts}^{\mathrm{h}} \underline{\varepsilon}^{\mathrm{H}}$ & $\mathrm{k}^{\mathrm{h}} \mathrm{e}^{33}$ \\
\hline 548.0 & rub (with hands) & 搓（措绳子） & 他_过 & & $v \underline{\varepsilon}^{L}$ & $\mathrm{k}^{21}$ \\
\hline 549.0 & rip; tear & 撕 & 他_过 & & $\mathrm{t} \int^{\mathrm{h}} \underline{e}^{\mathrm{L}}$ & $\mathrm{sl}^{33}$ \\
\hline 550.0 & twist; wring & 拧（拧毛巾） & 他_过 & $*_{\text {S-yök }}^{\mathrm{L}}$ & $\int \underline{\underline{L}}^{\mathrm{L}}$ & $\mathrm{ni}^{33}$ \\
\hline 551.0 & pick up & 拾（拾起） & 他_过 & & $\mathrm{gog}^{\mathrm{H}}$ & $\mathrm{ku}^{33}$ \\
\hline 552.0 & catch; seize & 捉（捉鸡） & 他_过 & $*_{\mathrm{s}-\mathrm{mi}}{ }^{1}$ & & $\mathrm{pu}^{55}$ \\
\hline 553.0 & scatter; sprinkle (e.g., seed) & 撒（撒种子） & 他_过 & & $\int \dot{\mathrm{t}}^{2}$ & $6 i^{33}$ \\
\hline 554.0 & throw away & 丢掉 & 他_过 & & ?lo ${ }^{\mathrm{H}}$ & $82^{33}$ \\
\hline 555.0 & pitch (throw from side way) & 摔（石头） & 他_过 & & Plo ${ }^{\mathrm{H}}$ & $1 a^{21} y^{33}$ \\
\hline 556.0 & toss (overhand) & 投 & 他_过 & & Plo ${ }^{\mathrm{H}}$ & \\
\hline 557.0 & stretch; stretch out & 伸（伸手） & 他_过 & $*_{\mathrm{s}-\mathrm{yak}^{\mathrm{L}}}$ & $\mathrm{d}_{3} \mathrm{e}^{3}$ & \\
\hline 558.0 & pound & 春/捣碎 & 他_过 & $* 2-\mathrm{di}^{2} \& * 2-$ ton $^{2}$ & $\mathrm{te}^{2}$ & $\mathrm{ti}^{55}$ \\
\hline 559.0 & lift (over head) & 举起 & 他_过 & $* \mathrm{kyi}^{2}$ & $\mathrm{tt}^{\mathrm{h}} \varepsilon^{2}$ & $\mathrm{ta}^{21}$ \\
\hline 560.0 & fold & 折 & 他_过 & $* \operatorname{tup}^{\mathrm{H}}$ & & $\mathrm{ts}^{21}$ \\
\hline 561.0 & squeeze & 挤压/榨 & 他_过 & ${ }^{*}$ s-nit ${ }^{\mathrm{L}} \& * \mathrm{C}-$ nap $^{\mathrm{L}} \& * \mathrm{tsit}^{\mathrm{H}}$ & $\mathrm{ni}^{\mathrm{L}}$ & $\mathrm{ti}^{33} \mathrm{tcin}^{21}$ \\
\hline 562.0 & pinch & 捏 & 他_过 & 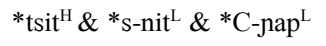 & $\mathrm{ts}^{\mathrm{h}^{\mathrm{L}} \underline{\underline{L}}^{\mathrm{L}}}$ & $\operatorname{ts}^{\mathrm{h}} 1^{33}$ \\
\hline 563.0 & massage & 按摩 & 他_过 & $*(\mathrm{~g}) \mathrm{yit}^{\mathrm{L}}$ & $3 \underline{i}^{\mathrm{L}}$ & \\
\hline 564.0 & bend & 使弯曲 & 他_过 & $*_{\text {səkok }}^{\mathrm{L}}$ & $\mathrm{go}^{\mathrm{L}}$ & $\mathrm{ku}^{55}$ \\
\hline 565.0 & pull a & 拉 & 他_过 & ${ }^{*} \mathrm{~m}$-gay ${ }^{1} \& *$ cway $^{2}$ & $x i^{3}$ & \\
\hline 565.1 & pull b & 拉 & 他_过 & $* \mathrm{~m}-$ gay $^{1} \& *$ cway $^{2}$ & $\operatorname{gay}^{1}$ & $\mathrm{ku}^{33}$ \\
\hline 566.0 & push & 推 & 他_过 & & $d y^{2}$ & $\mathrm{ti}^{33}$ \\
\hline 567.0 & kick & 踢 & 他_过 & $*$ tek $^{\mathrm{H}}$ & $\operatorname{tf}^{\mathrm{h}} \underline{\varepsilon}^{\mathrm{H}}$ & $\mathrm{ti}^{55}$ \\
\hline 568.0 & kneel & 趾 & 他_过 & & $\mathrm{git}^{2} \mathrm{t} \varepsilon^{1}$ & $\mathrm{ti}^{21}$ \\
\hline 569.0 & sit & 坐 & 他_过 & $*(\mathrm{C}) \mathrm{n} / \mathrm{i}-\mathrm{mi}^{1}$ & $\mathrm{ni}^{1}$ & wo $^{55}$ \\
\hline 570.0 & carry, on back & 背（背小孩） & 他_过 & $* \mathrm{bo}^{2} \& * \mathrm{bak}^{\mathrm{L}}$ & $\mathrm{bo}^{2}$ & $\mathrm{pe}^{55}$ \\
\hline 571.0 & carry, in arms & 抱（抱小孩） & 他_过 & & $\mathrm{te}^{\mathrm{H}}$ & $\mathrm{ta}^{55}$ \\
\hline 572.0 & carry, from hand & 提 & 他_过 & & $\mathrm{t} \int^{\mathrm{h}} \varepsilon^{2}$ & $\operatorname{ta}^{31}$ \\
\hline 573.0 & carry, mid pole & 担 & 他_过 & & py $^{2}$ & $\mathrm{ta}^{31}$ \\
\hline
\end{tabular}




\begin{tabular}{|c|c|c|c|c|c|c|}
\hline 574.0 & fall & 跌（跌倒） & 他_过 & & $2 l y^{2}$ & $\mathrm{p}^{\mathrm{h}} \mathrm{u}^{33}$ \\
\hline 575.0 & lean (against) & 靠（人靠在树上） & 他_过 & ${ }^{*} \mathrm{~s}-\mathrm{new}^{2} / 3 / \mathrm{ek}^{\mathrm{L}}$ & $\underline{e}^{\mathrm{H}}$ & $x_{i n}^{55}$ \\
\hline 576.0 & spend night & 过夜 & 他_过 & ${ }^{*} \mathrm{C}-\mathrm{yak}^{\mathrm{L}}$ & $h \underline{e}^{\mathrm{L}}$ & \\
\hline 577.0 & rest & 休息 & 他_过 & & $\mathrm{na}^{2}$ & $\mathrm{wo}^{55}$ \\
\hline 578.0 & sleep & 睡觉 & 他_过 & *yip ${ }^{\mathrm{L}}$ & $3 i^{\mathrm{L}} \mathrm{da}(\mathrm{y})^{2}$ & $\mathrm{zo}^{21}$ \\
\hline 579.0 & put to sleep & 使睡 & 他使他_过 & $*_{\text {səyip }}^{\mathrm{L}}$ & $x \underline{i}^{\mathrm{L}}$ & $\mathrm{zo}^{21} \mathrm{vi}^{21}$ \\
\hline 580.0 & awake & 醒（睡醒） & 他_过 & $*(C)-$ no $^{2}$ & $x^{2}{ }^{L}$ & nəy ${ }^{21}$ \\
\hline 581.0 & awaken & 唤醒 & 他_过 & $*_{\text {səno }}^{2}$ & $\mathrm{ku}^{2} \times \mathrm{a}^{\mathrm{L}}$ & $\mathrm{i}^{21} \mathrm{ku}^{33} \mathrm{tu}^{33}$ \\
\hline 582.0 & do (work) & 做（做工） & 他_过 & & $\mathrm{pe}^{1}$ & $\mathrm{za}^{55} \mathrm{məy}^{33}$ \\
\hline 583.0 & labor; work & 劳动 & 他_过 & $* \operatorname{mi}(\mathrm{aw})^{2} \& *[\mathrm{kam}]$ & $m j a^{2} \mathrm{ni}^{2} \mathrm{~m} \mathrm{u}^{1}$ & \\
\hline 584.0 & to plow & 犁（犁地） & 他_过 & & $\mathrm{mja}^{2}$ & $\mathrm{za}^{55} \mathrm{t}^{\mathrm{h}} \mathrm{a}^{33}$ \\
\hline 585.0 & $\operatorname{dig}($ a hole) & 挖（挖洞） & 他_过 & $* m-d u^{2}$ & $\mathrm{k} \underline{\varepsilon}^{\mathrm{L}}$ & $\mathrm{tu}^{21}$ \\
\hline 586.0 & plant; grow & 种 & 他_过 & & $\mathrm{k}^{\mathrm{h}} \mathrm{a}^{3}$ & $\mathrm{zu}^{33}$ \\
\hline 587.0 & water & 浇（浇菜） & 他_过 & & $x y^{2}$ & $\operatorname{sən}^{33}$ \\
\hline 588.0 & slice; cut & 切（切菜） & 他_过 & *?-dök ${ }^{\mathrm{H}}$ & $\mathrm{ts}^{\mathrm{h}} \underline{e}^{\mathrm{H}}$ & $\mathrm{so}^{21}$ \\
\hline 589.0 & slice; cut & 切 (切苹果、西瓜) & 他_过 & *?-brak ${ }^{\mathrm{H}}$ & $b \varepsilon^{2}$ & \\
\hline 590.0 & split; chop; cleave & 䢃（䢃木柴） & 他_过 & *2-brak ${ }^{\mathrm{H}}$ & $\mathrm{k}^{\mathrm{h}} \mathrm{j} \varepsilon^{2}$ & $\mathrm{k}^{\mathrm{h}} \mathrm{\partial}^{33}$ \\
\hline 591.0 & chop (down) & 砍（砍树） & 他_过 & $*_{\mathrm{m}}-\mathrm{cik}^{\mathrm{H}}$ & $\mathrm{k}^{\mathrm{h}} \underline{e}^{\mathrm{H}}$ & $\mathrm{p}^{\mathrm{h}} \mathrm{i}^{55}$ \\
\hline 592.0 & cut (reap) & 割（割稻） & 他_过 & $* \mathrm{rit}^{\mathrm{L}}$ & $\gamma \underline{\mathrm{i}}^{\mathrm{L}}$ & $\mathrm{y}^{21}$ \\
\hline 593.0 & whittle & 削 & 他_过 & $* \mathrm{di}^{1 / \beta}$ & $\mathrm{tf}^{\mathrm{h}} \mathrm{o}^{\mathrm{H}}$ & $\mathrm{ti}^{33}$ \\
\hline 594.0 & stab & 刺 & 他_过 & *m-gya/gay ${ }^{2}$ & $d 3^{L}$ & $6 \mathrm{i}^{33}$ \\
\hline 595.0 & pull up; pull out & 拔（拔草） & 他_过 & & $t \int \underline{i}^{\mathrm{H}}$ & $\mathrm{ko}^{33}$ \\
\hline 596.0 & graze; herd (a flock) & 放牧 & 他_过 & $*$ ?-lok ${ }^{\mathrm{L}}$ & $21 \underline{o}^{\mathrm{L}}$ & $1 u^{33}$ \\
\hline 597.0 & raise animals & 饲养 & 他_过 & $* \mathrm{~m}-\mathrm{yu}{ }^{1}$ & $\mathrm{hu}^{1}$ & $\mathrm{zu}^{45}$ \\
\hline 598.0 & lead along & 牵（牵牛） & 他_过 & & $\mathrm{si}^{3}$ & $\mathrm{ko}^{33}$ \\
\hline 599.0 & buy & 买 & 他_过 & $*$ way $^{1}$ & $v \varepsilon^{1}$ & $\mathrm{vu}^{33}$ \\
\hline 600.0 & sell & 卖 & 他_过 & $*(\mathrm{k})-\mathrm{rway}{ }^{2}$ & $v^{2}$ & $\eta^{21}$ \\
\hline 601.0 & count (number) & 数（数东西） & 他_过 & $*(\mathrm{k})$-raw ${ }^{1}$ & yo & $\mathrm{k}^{\mathrm{h}} \mathrm{a}^{33} \mathrm{ma}^{33}$ \\
\hline 602.0 & teach & 教 & 他_过 & $*_{\mathrm{s}-\mathrm{ma}^{2}}$ & $2 \mathrm{ma}^{2}$ & \\
\hline 602.1 & teach/train & 教 & 他_过 & & $\operatorname{tsan}^{3}$ & $\mathrm{tsu}^{33}$ \\
\hline 603.0 & study & 学 & 他_过 & $*[$ hen $] \& *$ m-dzay ${ }^{1}$ & $\mathrm{dzay}^{1}$ & $\operatorname{can}^{55}$ \\
\hline 604.0 & cook; boil & 煮 & 他_过 & ${ }^{*} \mathrm{C}-\mathrm{dzak}^{\mathrm{H}} \& * \mathrm{~m}-\mathrm{bi}^{1} / 2$ & $\mathrm{tse}^{\mathrm{L}}$ & $\mathrm{tsa}^{33}$ \\
\hline 605.0 & fry (stirfry) & 炒 & 他_过 & $*$ ?/g-raw ${ }^{1}$ & $2 l u^{1}$ & $1 u^{55}$ \\
\hline 606.0 & steam & 蒸 & 他_过 & $* \mathrm{C}$-sak ${ }^{\mathrm{L}}$ & $\mathrm{se}^{\mathrm{L}}$ & $\mathrm{sa}^{33}$ \\
\hline 607.0 & hunt; go hunting & 打猎 & 他_过 & ${ }^{*} \mathrm{~m}$-gak ${ }^{\mathrm{L}}$ & $\mathrm{kay}^{2} \mathrm{dzi}^{2} \mathrm{de}^{2}$ & \\
\hline 608.0 & shoot (a gun) & 射 & 他_过 & *(?)-kukL, *m-pökH & $\mathrm{b} \underline{\varepsilon}^{\mathrm{H}}$ & $\mathrm{pi}^{55}$ \\
\hline 609.0 & hit (a target) & 中（射中） & 他_过 & & $t^{h} u^{3}$ & $\mathrm{ta}^{21} \mathrm{pa}^{21}$ \\
\hline 610.0 & kill & 杀（杀鸡） & 他_过 & ${ }^{*} \mathrm{C}$-sat ${ }^{\mathrm{L}}$ & $\mathrm{se}^{\mathrm{L}}$ & $6 \mathrm{e}^{33}$ \\
\hline 611.0 & die & 死 & 他_过 & $* \int \mathrm{e}^{2}$ & $x \dot{i}^{1}$ & $\mathrm{~S}^{55}$ \\
\hline 612.0 & sharpen (grinding) & 磨（磨刀） & 他_过 & $* \mathrm{si}^{2}$ & $s \varepsilon^{2}$ & $\mathrm{k}^{21}$ \\
\hline 613.0 & mill (grinding) & 磨（磨米） & 他_过 & $* \mathrm{~m}-\mathrm{krit}^{\mathrm{H}}$ & $\operatorname{gan}^{3}$ & $\mathrm{lu}^{33} \mathrm{i}^{55} \mathrm{k \partial ^{33 }}$ \\
\hline 614.0 & winnow with a fan & 簸（筷米） & 他_过 & $* ?$-wa ${ }^{1}$ & $? \mathrm{va}^{1}$ & $\mathrm{p}^{\mathrm{h}} \mathrm{u}^{33}$ \\
\hline 615.0 & ladle out; spoon up & 舀（舀水） & 他_过 & & $\mathrm{k}^{\mathrm{h}} \underline{\mathrm{O}}^{\mathrm{L}}$ & $\mathrm{no}^{33}$ \\
\hline 616.0 & wear; put on & 穿（衣服） & 他_过 & *wat ${ }^{\mathrm{L}}$ & $v \underline{i}^{\mathrm{L}}$ & $\mathrm{je}^{31}, \mathrm{z}^{31}$ \\
\hline 617.0 & wear (hat); put on (hat) & 戴（帽子） & 他_过 & *?-kup ${ }^{\mathrm{H}}$ & $\mathrm{k}^{\mathrm{h}} \mathrm{O}^{\mathrm{H}}$ & $\operatorname{ts}^{\mathrm{h}} \curvearrowright \mathrm{y}^{33}$ \\
\hline 618.0 & wear (turban) & 戴(头巾) & 他_过 & $*$ C-net ${ }^{\mathrm{L}}$ & $\mathrm{so}^{\mathrm{L}}$ & $\mathrm{t}^{\mathrm{h}} \mathrm{o}^{45}$ \\
\hline 619.0 & wear (upper clothes) & 穿 (上衣) & 他_过 & $*$ m-dum ${ }^{1}$ & $v \underline{i}^{\mathrm{L}}$ & \\
\hline 620.0 & clothe & 给穿 & 他给他_过 & $*_{\text {səwat }}{ }^{\mathrm{L}}$ & $2 v^{\mathrm{L}} \mathrm{tu}^{3} / \mathrm{gu}^{2}$ & \\
\hline 621.0 & take off & 脱（脱衣服） & 他_过 & & $21 \underline{i}^{\mathrm{L}}$ & $1 i^{45}$ \\
\hline 622.0 & roll up & 卷（卷烟） & 他_过 & & $21 y^{3}$ & $\mathrm{t}^{\mathrm{h}} \mathrm{o}^{45}$ \\
\hline
\end{tabular}




\begin{tabular}{|c|c|c|c|c|c|c|}
\hline 623.0 & shave & 剃（头） & 他_过 & & $\mathrm{tg}^{\mathrm{h}} \underline{\mathrm{o}}^{\mathrm{H}}$ & $\operatorname{ts}^{\mathrm{h}} \partial^{33}$ \\
\hline 624.0 & comb & 梳（梳头） & 他_过 & $* 2-\mathrm{pi}^{2}$ & $\mathrm{pji}^{2}$ & $\mathrm{ka}^{33}$ \\
\hline 625.0 & dye & 染（染衣服） & 他_过 & & & $\mathrm{na}^{21}$ \\
\hline 626.0 & sew & 缝(缝衣服) & 他_过 & $*_{\text {gyup }}^{\mathrm{L}} \& *$ dap $^{\mathrm{L}}$ & $g \underline{u}^{\mathrm{L}}$ & $\mathrm{tu}^{31}$ \\
\hline 627.0 & mend; patch & 补（补衣服） & 他_过 & & $P n \varepsilon^{\mathrm{L}}$ & $\mathrm{ti}^{33}$ \\
\hline 628.0 & weave & 编织 & 他_过 & $* \mathrm{rak}^{\mathrm{L}}$ & $\mathrm{dz} \underline{\varepsilon}^{\mathrm{L}}$ & $\mathrm{ts}^{31}$ \\
\hline 629.0 & plait; braid & 编（编辫子） & 他_过 & & $\mathrm{p}^{\mathrm{h}} \mathrm{e}^{2}$ & $\mathrm{pi}^{21}$ \\
\hline 630.0 & make the bed & 铺（铺床） & 他_过 & & $\mathrm{k}^{\mathrm{h}} \mathrm{an}{ }^{2}$ & \\
\hline 631.0 & sweep & 扫（扫地） & 他_过 & $* \mathrm{sut}^{\mathrm{H}}$ & $\mathrm{si}^{\mathrm{H}}$ & $\mathrm{za}^{55}$ \\
\hline 632.0 & open & 开 (开门) & 他_过 & ${ }^{*}$ pwan $^{3} \& *$ blon $^{3}$ & $\mathrm{p}^{\mathrm{h}} \mathrm{u}^{3}$ & $\mathrm{ki}^{33}$ \\
\hline 633.0 & close & 关 ～～～～～～～ & 他_过 & $* \mathrm{hap}^{\mathrm{H}} \& * \mathrm{pi}^{2}$ & $\mathrm{ts}^{\mathrm{h}} \mathbf{i}^{21}$ & \\
\hline 634.0 & shut & 闭 (闭眼) & 他过 & & $\operatorname{ts}^{\mathrm{h}_{\underline{i}} \mathrm{H}}$ & $\mathrm{k}^{\mathrm{h}} \mathrm{a}^{33}$ \\
\hline 634.1 & shut & 闭 (闭眼) & 他_过 & & $\mathrm{mi}^{\mathrm{H}}$ & $\mathrm{mi}^{45}$ \\
\hline 635.0 & put down; put/place & 放（下）［放置］ & 他_过 & $* 2-\mathrm{ta}^{2}$ & $\tan ^{\mathrm{L}}$ & $p^{h^{3} i^{33}}$ \\
\hline 636.0 & release; let go; set free & 放（把鸟放走） & 他_过 & $*_{\mathrm{k}-\mathrm{lwat}}{ }^{\mathrm{H}}$ & $\mathrm{p}^{\mathrm{h}} \mathrm{jy} \mathrm{p}^{2}$ & $\mathrm{p}^{\mathrm{h}^{33}}$ \\
\hline 637.0 & hang & 挂（挂在墙上） & 他_过 & $*$ C-gyit ${ }^{\mathrm{L}} \& * 2-$ kuk $^{\mathrm{L}}$ & $\mathrm{k} \varepsilon^{1}$ & $x ә y^{55}$ \\
\hline 638.0 & tie into a bundle & 捆 (绑) & 他_过 & & $\mathrm{p}^{\mathrm{h}} \varepsilon^{3}$ & $\mathrm{p}^{\mathrm{h}} \mathrm{a}^{33}$ \\
\hline 639.0 & tie; bind & 系 & 他_过 & ${ }^{*}$ pay ${ }^{1}$ & $\mathrm{p}^{\mathrm{h}} \varepsilon^{3}$ & $\mathrm{p}^{\mathrm{h}} \mathrm{a}^{33}$ \\
\hline 640.0 & untie & 解 (解绳结) & 他_过 & $*$ pre $^{1}$ & $\mathrm{p}^{\mathrm{h}_{\mathrm{i}}{ }^{1}}$ & $\mathrm{p}^{\mathrm{h}^{55}}$ \\
\hline 641.0 & load; pack (put in) & 装（装进袋里） & 他_过 & $* 2-\mathrm{kun}^{3} / 2$ & $k \varepsilon^{3}$ & $\mathrm{ts}^{33}$ \\
\hline 642.0 & take out & 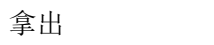 & 他_过 & *?-dwak ${ }^{\mathrm{H}} / \mathrm{ök}^{\mathrm{H}}$ & $v u^{1} t^{h} e^{L}$ & $\mathrm{vi}^{33} \mathrm{tue}^{55}$ \\
\hline 643.0 & press; fill in; squeeze in; stuff & 塞（塞在洞口） & 他_过 & ${ }^{*} \mathrm{C}-$-nap $^{\mathrm{L}} \&{ }^{*}$ s-nit ${ }^{\mathrm{L}} \& *$ tsit $^{\mathrm{H}}$ & $\mathrm{tsu}^{1}$ & $\mathrm{ti}^{21} \mathrm{ji}^{33}$ \\
\hline 644.0 & bury; cover up & 埋（埋物） & 他_过 & ${ }_{\text {səm- }}-\mathrm{du}{ }^{2}$ from dig m-du ${ }^{2}$ & ty $^{2}$ & $\mathrm{tu}^{31}$ \\
\hline 645.0 & hide (thing) & 藏（东西） & 他_过 & *səwak ${ }^{\mathrm{L}}$ & $\mathrm{t} \int \varepsilon^{1}$ & $\mathrm{xa}^{33}$ \\
\hline 646.0 & hide (self) & 藏/躲（自己） & 他_过 & $*_{\text {wak }^{\mathrm{L}}}$ & $v^{2}{ }^{2}$ & $\mathrm{xa}^{33}$ \\
\hline 647.0 & choose & 挑选 & 他_过 & & $\mathrm{se}^{1}$ & \\
\hline 648.0 & pile up; heap up & 堆（堆积泥土） & 他_过 & $*$ byum $^{1} \& *$ pup $/ \mathrm{uk}^{\mathrm{H}}$ & $\mathrm{k}^{\mathrm{h} \mathrm{jo}^{3}}$ & $\operatorname{tson}^{33}$ \\
\hline 649.0 & nail & 钉 (钉钉子) & 他_过 & & & \\
\hline 650.0 & want & 要（我要这个) & 他_过 & & $1 i^{1}$ & $\mathrm{xa}^{55}$ \\
\hline 651.0 & get; obtain; & 得（得到） & 他_过 & $* \mathrm{ra}^{3}$ & $\mathrm{ya}^{3}$ & $\mathrm{xa}^{55}$ \\
\hline 652.0 & receive & 收（收起来） & 他_过 & & sy $^{1}$ & $\mathrm{su}^{33}$ \\
\hline 653.0 & lose & 遗失 & 他_过 & & $\mathrm{p}^{\mathrm{h}^{\mathrm{i}} \underline{\mathrm{L}}^{\mathrm{L}}}$ & $\mathrm{pu}^{55}$ \\
\hline 654.0 & seek (look for) & 找/寻找 & 他_过 & $*_{\mathrm{x}-\mathrm{ra}^{1}}$ & $t \int a^{3}$ & $\mathrm{tsa}^{33}$ \\
\hline 655.0 & use & 用（使用） & 他_过 & ${ }^{*}$ zum $^{2} \& *_{\text {nay }}^{3}(<\# 850)$ & $z y^{2}$ & \\
\hline 656.0 & play & 玩 & 他_过 & $* \mathrm{~m}$-gre ${ }^{2} \& * 1-\mathrm{ga}^{3}$ & $\mathrm{ga}^{3}$ & $\mathrm{n}^{55} \mathrm{ka}^{33}$ \\
\hline 657.0 & win & 赢 & 他_过 & & $\mathrm{ya}^{\mathrm{L}}$ & $\mathrm{za}^{33}$ \\
\hline 658.0 & sing & 唱（歌） & 他_过 & $* \mathrm{mi}^{1} / \mathrm{ga}^{3}$ & $\mathrm{ga}^{3}$ & \\
\hline 659.0 & dance & 跳舞 & 他_过 & ${ }^{*} \mathrm{ga}^{3} \mathrm{~g} / \mathrm{k}(\mathrm{r}) \mathrm{un}^{1} / \mathrm{ut}^{\mathrm{H}}$ & $\mathrm{ga}^{3} \mathrm{k}^{\mathrm{h}} \mathrm{e} / \varepsilon^{3}$ & $\mathrm{pi}^{55}$ \\
\hline 660.0 & borrow (money) & 借（借钱） & 他_过 & $* \mathrm{kye}^{2}$ & $t \int^{h} i^{2}$ & $\mathrm{xa}^{33}$ \\
\hline 661.0 & borrow (thing) & 借(借东西) & 他_过 & $*_{s-n a^{2}}$ & $2 \mathrm{ga}^{2}$ & \\
\hline 662.0 & give back; return; repay & 还（还钱） & 他_过 & $*$ C-kok ${ }^{\mathrm{L}}$ & $\mathrm{si}^{1}$ & $\mathrm{k}^{\mathrm{h}} \mathrm{u}^{33}$ \\
\hline 663.0 & owe & 欠 & 他_过 & & $\mathrm{bo}^{3}$ & $\operatorname{ts}^{\mathrm{h}} \mathrm{ay^{33 }}$ \\
\hline 664.0 & compensate for; reimburse & 赔偿 & 他_过 & & $\mathrm{de}^{1}$ & $\mathrm{k}^{\mathrm{h}} \mathrm{u}^{33} \mathrm{ko}^{21}$ \\
\hline 665.0 & send-off; deliver & 送 & 他_过 & $* \mathrm{C}-\mathrm{po}^{3}$ & $x \varepsilon^{2} \mathrm{xa}^{1}$ & $\mathrm{pi}^{21}$ \\
\hline 666.0 & wait; await; expect & 等(候) & 他_过 & $* \mathrm{C}-1 \mathrm{o}^{3}$ & $\operatorname{Plan}^{3}$ & $\mathrm{tu}^{21}$ \\
\hline 667.0 & meet; come across & 遇见 & 他_过 & $\begin{array}{l}* \mathrm{dzo}^{1}{ }^{2} \& \\
* \mathrm{C}-\mathrm{do \eta}^{2} \& *[\text { phum }]\end{array}$ & $t^{h} u^{3} d z i^{1}$ & tso $^{33}$ \\
\hline 668.0 & marry a husband & 嫁 & 他_过 & & & $\mathrm{xo}^{55}$ \\
\hline 669.0 & marry a wife & 娶 & 他_过 & & $\mathrm{tsi}^{1}$ & $\mathrm{tsa}^{33}$ \\
\hline 670.0 & scold; curse & 骂 & 他_过 & & $\mathrm{k}^{\mathrm{h}} \mathrm{a}^{2}$ & $\mathrm{ko}^{33}$ \\
\hline
\end{tabular}




\begin{tabular}{|c|c|c|c|c|c|c|}
\hline 671.0 & fight & 打架 & 他_过 & & $d \varepsilon^{2} n^{2} d e^{L}$ & $\mathrm{ti}^{21} \mathrm{li}^{21} \mathrm{ma}^{33}$ \\
\hline 672.0 & hit; beat & 打（打人） & 他_过 & $* \mathrm{~m}-$ tok $^{\mathrm{H}} \& * \mathrm{~m}-\mathrm{di}^{2}$ & $\mathrm{~d} \varepsilon^{2}$ & $\mathrm{ti}^{21}$ \\
\hline 673.0 & rob; loot & 抢 & 他_过 & & ho $^{3}$ & nəy ${ }^{33}$ \\
\hline 674.0 & steal & 偷 & 他_过 & $* \mathrm{ko}^{2}$ & $\mathrm{k}^{\mathrm{h}} \mathrm{o}^{2}$ & $\mathrm{k}^{\mathrm{h}} \mathrm{u}^{33}$ \\
\hline 675.0 & cheat & 骗 & 他_过 & & $\mathrm{ke}^{\mathrm{L}}$ & \\
\hline 676.0 & help & 帮助 & 他_过 & $*_{\operatorname{gra}^{3}}$ & $\mathrm{gja}^{3}$ & $\mathrm{ka}^{33}{\mathrm{p} ə \mathrm{y}^{21}}^{21}$ \\
\hline 677.0 & cure; treat; heal & 医治 & 他_过 & ${ }^{*}$ səC-na ${ }^{1}$ & gor $^{3}$ & $\mathrm{na}^{33} \mathrm{ni}^{55}$ \\
\hline 678.0 & divide; separate; distribute & 分 & 他_过 & ${ }^{*}$ bay $^{1} \& *$ C-klay ${ }^{1 / 3}$ & by $^{1}$ & $\mathrm{pi}^{33}$ \\
\hline 679.0 & laugh & 笑 & 他_过 & $*^{*}{ }^{1}{ }^{1}$ & $\gamma \varepsilon^{1}$ & $82^{33}$ \\
\hline 680.0 & cry & 哭 & 他_过 & $*_{\text {yo }}{ }^{1}$ & yo $^{1}$ & $x ә y^{33}$ \\
\hline 681.0 & love & 爱（爱小孩） & 他_过 & $*[\mathrm{hak}]$ & $s \varepsilon^{2}$ & $\mathrm{ni}^{55} \mathrm{tso}^{33}$ \\
\hline 682.0 & like; enjoy & 喜欢（喜欢唱歌） & 他_过 & & & əฑ ${ }^{55} \mathrm{ma}^{33} \mathrm{k}^{33}$ \\
\hline 683.0 & know; understand & 懂；知道 & 他_过 & $* \mathrm{si}^{2}$ & $s \underline{\varepsilon}^{L}$ & $6 \mathrm{a}^{21}$ \\
\hline 684.0 & remember & 记得 & 他_过 & & $\mathrm{xa}^{\mathrm{L}}$ & $n \partial^{21}$ \\
\hline 685.0 & forget & 忘记 & 他_过 & $* 1-\mathrm{me}^{3}$ & $m a^{2} x a^{L}$ & $\mathrm{ma}^{21} \mathrm{o}^{21}$ \\
\hline 686.0 & think & 思考 & 他_过 & $*^{m}$-dan ${ }^{2}$ & $\mathrm{di}^{2}$ & $\mathrm{tu}^{21} \mathrm{ni}^{55}$ \\
\hline 687.0 & be angry & 生气 & 他_过 & *?-(d)zup ${ }^{\mathrm{H}}$ & & $\mathrm{na}^{55}$ \\
\hline 688.0 & hate & 恨 & 他_过 & & $\operatorname{ts}^{h^{2}}{ }^{2}$ & \\
\hline 689.0 & fear & 怕 & 他_过 & *(sə)-grok ${ }^{\mathrm{H}}$ & $\mathrm{gjo}^{\mathrm{H}}$ & $\mathrm{ku}^{33}$ \\
\hline 690.0 & have courage & 敢 & 他_过 & & $\mathrm{p} \dot{\mathrm{i}}^{2}$ & \\
\hline 691.0 & can (well) & 会（会做） & 他_过 & $*$ ?-put ${ }^{\mathrm{L}} \& * \mathrm{na}^{3}$ & $\mathrm{k}^{\mathrm{h}} \varepsilon^{1}$ & $6 \mathrm{a}^{21}$ \\
\hline 692.0 & affirmative & 是（这是什么） & 他_过 & $* \mathrm{ya}^{3} /{ }^{1}$ & $\mathrm{ya}^{1}$ & $\mathrm{xin}^{55}$ \\
\hline 693.0 & is not & 不是 (这不是我的) & 他_过 & & $m a^{2} \mathrm{ya}^{1}$ & $\mathrm{ma}^{21} \mathrm{xiy}^{55}$ \\
\hline 694.0 & have & 有 & 他_过 & $*_{\text {jay }}{ }^{1}$ & $\mathrm{~d}_{3} a y^{1}$ & $v^{33}$ \\
\hline 695.0 & not have; lack; without & 没有 (我没有书) & 他_过 & & $m a^{2} d z a \eta^{1}$ & $m a^{21} v^{33}$ \\
\hline 696.0 & walk & 走 & 他_过 & $* \mathrm{~m}-\mathrm{ju} / \mathrm{on}^{2} \& * \mathrm{du}^{2}$ & $\mathrm{sy}^{2}$ & to $^{21}$ \\
\hline 697.0 & run & 跑 & 他_过 & $* \mathrm{p}-\mathrm{re}^{2}$ & $g j \varepsilon^{2}$ & $\mathrm{t}^{\mathrm{h}} \mathrm{i}^{33}$ \\
\hline 698.0 & ascend & 上（上山） & 他_过 & $* 1-\mathrm{dak}^{\mathrm{H}}$ & $\mathrm{de}^{\mathrm{H}}$ & $\operatorname{tai}^{55}$ \\
\hline 699.0 & descend & 下（下山） & 他_过 & $*^{3} \mathrm{ak}^{\mathrm{L}}$ & $\mathrm{ze}^{\mathrm{L}}$ & $\mathrm{ja}^{33}$ \\
\hline 700.0 & come & 来 & 他_过 & $* 1 a^{1} \& * 1 i^{3}$ & $1 a^{1}$ & $1 a^{33}$ \\
\hline 701.0 & come up & 上来 & 他_过 & $* 1 a^{1}$ & $d e^{\mathrm{H}} l a^{1}$ & $\mathrm{ta}^{33} \mathrm{li}^{55}$ \\
\hline 702.0 & come down & 下来 & 他_过 & $* 1 \mathrm{i}^{3}$ & $\mathrm{ze}^{\mathrm{L}} \mathrm{la}{ }^{1}$ & $\mathrm{ja}^{21} \mathrm{li}^{33}$ \\
\hline 703.0 & go & 去 & 他_过 & ${ }^{*} \mathrm{x}-\mathrm{ra}^{1}$ & $3 e^{1}$ & $z_{1}^{33}$ \\
\hline 704.0 & go up & 上去 & 他_过 & $* 1 e^{3}$ & $\mathrm{de}^{\mathrm{H}} \mathrm{e}^{1}$ & $\operatorname{tai}^{55}$ \\
\hline 705.0 & go down & 下去 & 他_过 & $*$ ay $^{1}$ & $\mathrm{ze}^{\mathrm{L}} 3 \mathrm{e}^{1}$ & $\mathrm{ja}^{33}$ \\
\hline 706.0 & climb & 爬 (上) & 他_过 & & $2 \mathrm{~m} \varepsilon^{\mathrm{H}}$ & $\mathrm{ta}^{33}$ \\
\hline 707.0 & return & 回 & 他_过 & $*_{\text {gok }^{\mathrm{L}}}$ & ty $^{1}$ & $\mathrm{ku}^{21} \mathrm{li}^{33}$ \\
\hline 708.0 & arrive & 到 & 他_过 & $*(\mathrm{k})-\mathrm{rok}^{\mathrm{H} / \mathrm{L}}$ & $\mathrm{k}^{\mathrm{h}} \mathrm{je}^{1}$ & $\mathrm{k}^{\mathrm{h}} \mathrm{\partial}^{55}$ \\
\hline 709.0 & cross (over) & 过（过河） & 他_过 & & $\mathrm{kjo}^{\mathrm{L}}$ & $\mathrm{tc}^{33}$ \\
\hline 710.0 & go through & 经过 & 他_过 & & $\mathrm{kog}^{\mathrm{L}}$ & \\
\hline 711.0 & exit (come out) & 出（出去） & 他_过 & *1-dwak ${ }^{\mathrm{H}} / 0 \ddot{\mathrm{k}}{ }^{\mathrm{H}}$ & $\mathrm{do}^{\mathrm{H}}$ & tue $\mathrm{e}^{55}$ \\
\hline 712.0 & enter & 进（进来） & 他_过 & ${ }^{*}$ way $^{1} \& * \operatorname{luk} / \mathrm{ap}^{\mathrm{L}}$ & $d y^{2}$ & $\mathrm{ni}^{21} \mathrm{li}^{33}$ \\
\hline 713.0 & move back & 退 & 他_过 & & & \\
\hline 714.0 & flee; escape & 逃 & 他_过 & ${ }^{*}$ paw $^{1}$ & $\mathrm{k}^{\mathrm{h}} \mathrm{u}^{2} \mathrm{gj} \varepsilon^{2}$ & $\mathrm{t}^{\mathrm{h}} \mathrm{i}^{33}$ \\
\hline 715.0 & chase & 追（追上） & 他_过 & & $\mathrm{t} \int \mathrm{u}^{2}$ & $\mathrm{ka}^{31}$ \\
\hline 716.0 & step on & 踩 & 他_过 & & $\mathrm{k}^{\mathrm{h}^{3}}{ }^{3}$ & $n u^{21}$ \\
\hline 717.0 & jump; leap & 跳 & 他_过 & *2-bok ${ }^{\mathrm{H}}$ & $\mathrm{p} \varepsilon^{\mathrm{H}}$ & $\mathrm{pi}^{55}$ \\
\hline 718.0 & stride & 跨（跨小沟） & 他_过 & & & $\mathrm{zl}^{33}$ \\
\hline 719.0 & ride; ride on & 骑（骑马） & 他_过 & $* \mathrm{dzi}^{2}$ & $\mathrm{dz} \varepsilon^{2}$ & $\operatorname{tai}^{55}$ \\
\hline 720.0 & EXIST; to be & 在；有 & 他_过 & ${ }^{*} \mathrm{C}$-plek ${ }^{\mathrm{L}}$ & $\mathrm{d} 3 \mathrm{e}^{\mathrm{H}}$ & wo $^{55}$ \\
\hline
\end{tabular}




\begin{tabular}{|c|c|c|c|c|c|c|}
\hline 721.0 & dry (in the sun) & 晒（晒太阳） & & & $21 y^{\mathrm{L}}$ & $10^{33}$ \\
\hline 722.0 & $\operatorname{rain}(\mathrm{V})$ & 下雨 ～～～ & & & $\mathrm{ha}^{1}$ & $\mathrm{mi}^{21} \mathrm{ji}^{33}$ \\
\hline 723.0 & (of the wind) blow & 刮风 & & & $\mathrm{k}^{\mathrm{h}} \mathrm{y}^{1}$ & $\mathrm{mi}^{21} \mathrm{li}^{55} \mathrm{li}^{55}$ \\
\hline 724.0 & light (on fire) & 点（点火） & 他_过 & $*_{\text {səduk }}^{\mathrm{L}}$ & $\mathrm{to}^{\mathrm{L}}$ & $\mathrm{tu}^{33}$ \\
\hline 725.0 & burn & 焚（烧） & 他_过 & $* \operatorname{duk}^{\mathrm{L}}$ & $\mathrm{k}^{\mathrm{h}} \mathrm{u}^{1}$ & $\operatorname{ts}^{\mathrm{h}} 1^{55}$ \\
\hline 726.0 & burn up & 烧掉 & 他_过 & & $\mathrm{k}^{\mathrm{h}} \mathrm{u}^{1}$ & $\operatorname{ts}^{\mathrm{h}} \Upsilon^{55} \mathrm{jo}^{21}$ \\
\hline 727.0 & roast (in fire) & 烧 (火里) & 他_过 & $*$ put $^{\mathrm{H}} \& \mathrm{cit} / \mathrm{et}^{\mathrm{H}}$ & & \\
\hline 728.0 & roast (over fire) & 烤 (火上) & 他_过 & $*$ ?-gan ${ }^{1}$ & $\operatorname{kay}^{1}$ & $\mathrm{ku}^{55}$ \\
\hline 729.0 & smoke & 冒烟 & 它_过 & $*(\mathrm{C})-\int \mathrm{uk}^{\mathrm{H} / \mathrm{L}}$ & $\int \underline{\underline{H}}^{\mathrm{H} / \mathrm{L}}$ & $\mathrm{mo}^{21} \mathrm{sa}^{33}$ \\
\hline 730.0 & explode & 爆炸 & 它_过 & & $\mathrm{bu}^{\mathrm{H}}$ & $\mathrm{pie}^{33}$ \\
\hline 731.0 & flow & 流（水流） & 它_过 & & $\int \mathrm{i}^{3}$ & $\mathrm{za}^{21} \mathrm{li}^{33}$ \\
\hline 732.0 & overflow; spill & 溢 & 它_过 & ${ }^{*} x_{w a n}{ }^{2} \& * x a^{H}$ & $\gamma \underline{y}^{\mathrm{L}}$ & $6 i^{55}$ \\
\hline 733.0 & float & 浮（浮在水面） & 它_过 & & & $\mathrm{po}^{33}$ \\
\hline 734.0 & crack open; split open & 裂开（墙裂开） & 它_过 & & $\mathrm{be}^{\mathrm{L}}$ & $\mathrm{pie}^{33}$ \\
\hline 735.0 & collapse; topple down & 倒塌 & 它_过 & & by $^{2}$ & $\mathrm{yai}^{55}$ \\
\hline 736.0 & be short of; lack & 缺（碗缺了一个口） & 它_过 & & $\mathrm{k}^{\mathrm{h}} \underline{\varepsilon}^{\mathrm{L}}$ & $\mathrm{k}^{\mathrm{h}} \mathrm{e}^{33}$ \\
\hline 737.0 & roll & 滚（石头滚） & 它_过 & $*(\mathrm{C})-\lim ^{3}$ & $21 y^{3} / 2$ & $\mathrm{ka}^{33} \mathrm{ja}^{33}$ \\
\hline 738.0 & revolve; rotate; spin & 旋转 & 它_过 & $* g-w a{ }^{1}$ & $\operatorname{t} \operatorname{san}^{1}$ & $\mathrm{tsu}^{55}$ \\
\hline 739.0 & fall; drop & 掉（掉在地下） & 它_过 & $*(\mathrm{~s} ə)-$ gla $^{3} \& *(?)-$ tse $^{1}$ & $\mathrm{ts}^{\mathrm{h}} \mathrm{e}^{1}$ & $\mathrm{kai}^{55}$ \\
\hline 740.0 & snap in two (rope, string) & 断（绳子断了） & 它_过 & & $\mathrm{ts}^{\mathrm{h}} \underline{e}^{\mathrm{H}}$ & $\operatorname{kə\eta }^{55}$ \\
\hline 741.0 & break & 破（罐子破了） & 罐子_过 & $* \operatorname{cit}^{\mathrm{H}}$ & & $\mathrm{pie}^{33}$ \\
\hline 742.0 & leak & 漏（水桶漏水） & 它_过 & & & $\mathrm{tu}^{33}$ \\
\hline 743.0 & boil & 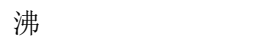 & 它_过 & $* \mathrm{C}-\mathrm{dzak}^{\mathrm{H}} \& * \mathrm{~m}-\mathrm{bi}{ }^{1} / 2$ & $\mathrm{tsu}^{1}$ & $\mathrm{k} \partial^{33}$ \\
\hline 744.0 & change & 变（蛹变蛾） & 它_过 & & & $\mathrm{pa}^{55}$ \\
\hline 745.0 & birth & 生（生孩子） & 他_过 & baw $^{3}$ be born & $\mathrm{b} \varepsilon^{3}$ & $\mathrm{zu}^{45}$ \\
\hline 746.0 & grow & 长（长大） & 他_过 & & $\gamma \varepsilon^{2}$ & $82^{33}$ \\
\hline 747.0 & tremble; shiver & 发抖 & 他_过 & & $t \int^{h} e^{2}$ & $\mathrm{tsu}^{33}$ \\
\hline 748.0 & swell & 肿 & 他_过 & ${ }^{*} \mathrm{C}-$ pwam $^{2} / \mathrm{ap}^{\mathrm{L}} \& *$ sə-roy ${ }^{2}$ & $\mathrm{p}^{\mathrm{h}} \mathrm{y}^{\mathrm{L}}$ & $\mathrm{fu}^{55}$ \\
\hline 749.0 & fly & 飞 & 它_过 & $*(b)-y^{1}$ & bjy $^{1}$ & $\mathrm{pu}^{33}$ \\
\hline 750.0 & bark & 吠 (狗叫) fei & 它_过 & $* \mathrm{~h} / \mathrm{lo \eta}^{1}$ & $1 u^{3}$ & $\operatorname{mon}^{33}$ \\
\hline 751.0 & call; crow (of animals) & 啼（公鸡啼） & 它_过 & & bo $^{1}$ & $\mathrm{ku}^{33}$ \\
\hline 752.0 & lay (an egg) & 生（生蛋） & 它_过 & & $f u^{3}$ & $\mathrm{vu}^{55}$ \\
\hline 753.0 & brood, incubate & 孵 & 它_过 & & $2 m y^{2}$ & $\mathrm{mu}^{21}$ \\
\hline 754.0 & germinate, sprout, bud & 发(芽) & 它_过 & & $\mathrm{b} \underline{\underline{i}}^{\mathrm{H}}$ & $\mathrm{pu}^{33}$ \\
\hline 755.0 & bloom; blossom & 开(花) & 它_过 & & $2 \mathrm{ve}^{\mathrm{H}}$ & $\mathrm{vi}^{55}$ \\
\hline 756.0 & bear fruit & 结 (果) & 它_过 & & $d_{3} \varepsilon^{2}$ & to $^{21}$ \\
\hline 757.0 & rot (fruit) & 腐烂 & 它_过 & $*_{m}$-bup ${ }^{L}$ & $\mathrm{p}^{\mathrm{h}} \dot{\mathrm{t}}^{2}$ & $n ə \eta^{21}$ \\
\hline 758.0 & begin; start & 开始 & 他_过 & $* 2-\mathrm{ta}^{2}$ & $\mathrm{tu}^{1}$ & $\mathrm{ko}^{33} \mathrm{ka}^{21}$ \\
\hline 759.0 & stop & 停 & 他_过 & $* \mathrm{tso}^{3} / \mathrm{up}^{\mathrm{H}} \& * \mathrm{~m}-\mathrm{jay}^{2}$ & $\mathrm{na}^{2}$ & wo $^{55}$ \\
\hline 760.0 & remain & 留下 & 他_过 & $*[1 ə]$ & & $\mathrm{t}^{\mathrm{h}} \mathrm{a}^{33} \mathrm{ts}^{33}$ \\
\hline 761.0 & write & 写 & 他_过 & $*$ m-bup ${ }^{\mathrm{L}}$ & $2 \mathrm{v} \underline{\varepsilon}^{\mathrm{H}}$ & $\mathrm{k} \partial^{21}$ \\
\hline 762.0 & wash (self) & 洗 (手) & 他_过 & $\mathrm{tse}^{2}$ & $\mathrm{ts}^{\mathrm{h}^{2}}{ }^{2}$ & $\mathrm{ts}^{\mathrm{h}} 1^{33}$ \\
\hline 763.0 & get up & 起来 & 他_过 & & $\mathrm{tu}^{1}$ & $\mathrm{tu}^{55} \mathrm{ta}^{55}$ \\
\hline 764.0 & shake & 摇动 & 他_过 & ${ }^{*} \mathrm{k}-\operatorname{lup}^{\mathrm{H}}$ & $2 l \underline{u}^{\mathrm{H}}$ & $\mathrm{ni}^{33}$ \\
\hline 765.0 & sink & 沉 (下) & 他_过 & & & $\mathrm{ja}^{33}$ \\
\hline 766.0 & finish & 完成 & 他_过 & $*$ bran $^{1}$ & & $\mathrm{tci}^{33} \mathrm{tu}^{21}$ \\
\hline 767.0 & give; BEN & 给 & 他_过 & $* \mathrm{be}^{2}$ & $\mathrm{gu}^{2}$ & $\mathrm{pi}^{21}$ \\
\hline 768.0 & destroy & 破坏 & 他_过 & ${ }^{*}$ pyak $^{\mathrm{H}}$ & $\mathrm{p}^{\mathrm{h}} \underline{e}^{\mathrm{H}}$ & $\mathrm{ma}^{21} \mathrm{la}^{21}$ \\
\hline 769.0 & draw water (well) & 吊（水） & 他_过 & & & $x ә y^{55}$ \\
\hline 770.0 & drain, to & 排（水） & 他_过 & & $\mathrm{p}^{\mathrm{h}} \mathrm{e}^{2}$ & $\mathrm{p}^{\mathrm{h}^{3} \mathrm{i}^{33}}$ \\
\hline
\end{tabular}




\begin{tabular}{|c|c|c|c|c|c|c|}
\hline 771.0 & be standing & 站（站位） & 他_过 & $*$ ?-tu/oy ${ }^{1} ; *$-ryapL & hy ${ }^{\mathrm{L}}$ & $\mathrm{zo}^{33}$ \\
\hline 772.0 & skin (animal), to & 剥皮 & 他_过 & & $\operatorname{ts}^{\mathrm{h}^{\mathrm{L}}} \underline{\underline{L}}^{\mathrm{L}}$ & $\mathrm{li}^{33}$ \\
\hline 773.0 & peel (eggs, fruit) & 剥 & 他_过 & & & \\
\hline 774.0 & clear field & 除田 & 他_过 & $* \mathrm{C}-\mathrm{mya}^{2}$ & & $\mathrm{tu}^{33}$ \\
\hline 775.0 & weed & 除草 & 他_过 & ${ }^{*} \mathrm{C}-\mathrm{mruk}^{\mathrm{L}}$ & $\operatorname{mog}^{\mathrm{L}}$ & $\mathrm{tu}^{33}$ \\
\hline 776.0 & stir & 搅拌 & 他_过 & $* \mathrm{~m}-\mathrm{kok}^{\mathrm{H}}$ & $\mathrm{g}_{\underline{\varepsilon}}^{\mathrm{H}}$ & $1 a^{55}$ \\
\hline 777.0 & weigh & 称 & 他_过 & $* \operatorname{ts} \sin ^{1}$ & $\mathrm{ki}^{1}$ & \\
\hline 778.0 & soak; pickle & 泡 & 他_过 & & $\mathrm{ti}^{\mathrm{H}}$ & $\mathrm{ti}^{55}$ \\
\hline 779.0 & drown & 淹死/溺死 & 他_过 & & & $\mathrm{ti}^{55} \mathrm{nəy}^{21}$ \\
\hline 780.0 & accompany someone & 陪 & 他_过 & & $t \int^{h} u^{1}$ & $\mathrm{k}^{\mathrm{h}} \mathrm{u}^{33}$ \\
\hline 781.0 & swim & 游泳 & 他_过 & $*[1 \supset j]$ & $\mathrm{yi}^{1} \mathrm{ga}^{3}$ & $\mathrm{n}^{55} \mathrm{ka}^{33}$ \\
\hline 782.0 & drill (a hole) & 钻（钻孔） & 他_过 & & $\mathrm{t}^{\mathrm{h}} \mathrm{u}^{1}$ & tso $^{55}$ \\
\hline 783.0 & insert & 插 & 他_过 & & $\mathrm{ts}^{\mathrm{h}} \underline{y}^{\mathrm{H}}$ & $\operatorname{ts}^{\mathrm{h}} \mathrm{o}^{55}$ \\
\hline 784.0 & drive out & 赶（驱逐） & 他_过 & & $\mathrm{ga}^{\mathrm{L}}$ & $\mathrm{ka}^{21}$ tui $^{55}$ \\
\hline 785.0 & wither & 枯（树叶枯） & 他_过 & ${ }^{*}$ s-we ${ }^{2} \& *$ gwe $^{3}($ dry $)$ & $\mathrm{gu}^{3}$ & \\
\hline 786.0 & cough & 咳嗽 & 他_过 & $* \mathrm{tso}^{2} \& * ?-\mathrm{kyay}^{2}$ & $\mathrm{tsi}^{2}$ & $\mathrm{tsu}^{33} \mathrm{tsu}^{33}$ \\
\hline 787.0 & yawn & 打呵欠 & 他_过 & $* \mathrm{ha}^{2} / 3 \mathrm{mi}^{1}$ & $2 \mathrm{li}^{\mathrm{L}} \mathrm{ku}^{3}$ & $\mathrm{tsu}^{33}$ \\
\hline 788.0 & sneeze & 打喷德 & 他_过 & $* \mathrm{ha}^{1} \mathrm{kye}^{2}$ & $\mathrm{ha}^{1}$ & \\
\hline 789.0 & hiccup & 打嗝 & 他_过 & $* ? \mathrm{ut}^{\mathrm{H}}$ & $\underline{\underline{i}}^{\mathrm{H}}$ & \\
\hline 790.0 & belch & 打饱嗝 & 他_过 & $* \mathrm{ut}^{\mathrm{L}} / \mathrm{an}^{1}$ & $\underline{\underline{i}}^{\mathrm{L}}$ & \\
\hline 791.0 & fart & 放屁 & 他_过 & $* \mathrm{p}(\mathrm{y}) \mathrm{aw}^{2} \& * \mathrm{dek}^{\mathrm{L}}$ & $\mathrm{bjo}^{2} \mathrm{ts}^{\mathrm{h}} \mathrm{P}^{2} \mathrm{bjo}^{2}$ & $\operatorname{ts}^{\mathrm{h}} 1^{33} \mathrm{ts}^{\mathrm{h}} 1^{33}$ \\
\hline 792.0 & defecate & 解大便 & 他_过 & $* 1-\mathrm{ko}^{2}$ & $\mathrm{k}^{\mathrm{h}} \mathrm{ji}^{2} \varepsilon^{2}$ & $\operatorname{ts}^{\mathrm{h}}{ }^{33} \mathrm{y}^{55}$ \\
\hline 793.0 & urinate & 解小便 & 他_过 & $* \int \mathrm{i}^{2}$ & $z i^{2} t \int^{h} e^{H}$ & $\mathrm{n}^{21} \operatorname{ts}^{\mathrm{h}} 1^{33} \mathrm{la}^{55}$ \\
\hline 794.0 & scratch & 挠/搔 & 他_过 & $* \mathrm{~m}-\mathrm{krak}^{\mathrm{H}} \sim \mathrm{m}-\mathrm{prak}^{\mathrm{H}}$ & $\mathrm{ku}^{2}$ & $\mathrm{ka}^{55}$ \\
\hline 795.0 & live & 活 & 他_过 & $*_{\mathrm{c} / \mathrm{jya}}{ }^{2} \& \mathrm{ni}^{2}$ & $\mathrm{z} \varepsilon^{1}$ & $\mathrm{ti}^{21}$ \\
\hline 796.0 & exchange & 交换 & 他_过 & $*$ ?-pa ${ }^{1}$ & $\mathrm{pa}^{1}$ & $\mathrm{pa}^{55}$ \\
\hline 797.0 & butt & (用头) 碰撞 & 他_过 & $\begin{array}{l}{ }^{*} \mathrm{~m}-\mathrm{krap}^{\mathrm{H}} \& \\
* \mathrm{l}-\mathrm{m}-\mathrm{co \eta}^{3} \& \text { ton }^{1}\end{array}$ & $t^{\mathrm{h}} \mathrm{u}^{3}$ & $\mathrm{ti}^{21} \mathrm{tso}^{33}$ \\
\hline 798.0 & white & 白 & 它_了 & $*$ plu $^{1}$ & $\mathrm{p}^{\mathrm{h}} \mathrm{u}^{1}$ & $\mathrm{p}^{\mathrm{h}} \mathrm{u}^{55}$ \\
\hline 799.0 & black & 黑 & 它_了 & ${ }^{*} \mathrm{C}-$ nak $^{\mathrm{H}}$ & $2 n e^{\mathrm{H}}$ & $\mathrm{na}^{33}$ \\
\hline 800.0 & red & 红 & 它_了 & $*$ ?-ni ${ }^{1}$ & $\mathrm{Pni}^{1}$ & $\mathrm{ni}^{55}$ \\
\hline 801.0 & yellow & 黄 & 它_了 & $*_{\text {S-rwe }}^{1}$ & $\int \varepsilon^{1}$ & $\mathrm{sl}^{55}$ \\
\hline 802.0 & blue & 蓝 & 它_了 & $* \operatorname{bra}^{1} \& *[\operatorname{lan}]$ & $2 n i^{1}$ & $\mathrm{n} \partial^{55}$ \\
\hline 803.0 & green & 绿 & 它_了 & *2-no ${ }^{1}$ & $2 \mathrm{ni}^{1}$ & $n 2^{55}$ \\
\hline 804.0 & grey & 灰色 & 它_了 & $* \mathrm{pe}^{1}$ & $\mathrm{p}^{\mathrm{h}} \varepsilon^{1}$ & $n a^{33} p^{h} u^{55}$ \\
\hline 805.0 & sharp (point) & 尖（笔嘴很尖） & 它_了 & & $\mathrm{ts}^{\mathrm{h}} \mathrm{y}^{1}$ & $\mathrm{t}_{6} \mathrm{i}^{\mathrm{h}}{ }^{55}$ \\
\hline 806.0 & sharp (blade) & 快（刀快） & 它_了 & $* \operatorname{tak}^{\mathrm{H}}$ & $\mathrm{t}^{\mathrm{h}} \underline{\underline{H}}^{\mathrm{H}}$ & $\mathrm{t}^{\mathrm{h}} \mathrm{a}^{55}$ \\
\hline 807.0 & dull & 钝（刀钝） & 它_了 & $* \mathrm{dum}^{2}$ & $d u^{2}$ & $\mathrm{ma}^{21} \mathrm{t}^{\mathrm{h}} \mathrm{a}^{55}$ \\
\hline 808.0 & round & 圆（球很圆） & 它_了 & ${ }^{*}$ woy $^{2}$ & $\mathrm{va}^{3}$ & $\mathrm{lu}^{33}$ \\
\hline 809.0 & flat & 平 (路很平) & 它_了 & $*$ ?-bra ${ }^{2}$ & $\mathrm{~b} \varepsilon^{1}$ & $\mathrm{pa}^{33}$ \\
\hline 810.0 & steep & 陡（山很陡） & 它_了 & & & \\
\hline 811.0 & situated straight & 正（帽子戴得正） & 它_了 & & & $\mathrm{tu}^{33}$ \\
\hline 812.0 & situated crooked & 歪（帽子戴歪了） & 它_了 & & & $x^{33}$ \\
\hline 813.0 & straight & 直（棍子很直） & 它_了 & $*(\mathrm{C})-\mathrm{dwa \eta}^{1} \& * \mathrm{te}^{2}$ & $\mathrm{~d}_{3} a \mathrm{y}^{2}$ & \\
\hline 814.0 & crooked; bent & 弯（棍子弯） & 它_了 & $* \operatorname{gok}^{\mathrm{L}}$ & $\mathrm{go}^{\mathrm{L}}$ & $\mathrm{ku}^{31}$ \\
\hline 815.0 & thick; dense & 稠（粥很稠） & 它_了 & & $\mathrm{t}^{\mathrm{h}} \mathrm{ay^{2 }}$ & $\mathrm{t}^{\mathrm{h}} \mathrm{i}^{33}$ \\
\hline 816.0 & thin; watery; sparse & 稀（粥很稀） & 它_了 & & & \\
\hline 817.0 & hard & 硬 & 它_了 & $* \operatorname{krok}^{\mathrm{H}} \& *[\mathrm{k} \varepsilon \eta] \& *[\mathrm{~h} \varepsilon \dashv]$ & $\mathrm{k}^{\mathrm{h}} \underline{a}^{\mathrm{H}}$ & $\mathrm{k}^{\mathrm{h}} \mathrm{a}^{55}$ \\
\hline 818.0 & soft & 软 & 它_了 & $* \mathrm{C}-\mathrm{nu}^{2}$ & $n u^{2}$ & $\mathrm{no}^{33}$ \\
\hline 819.0 & bright; light & 亮（房子很亮） & 它_了 & $* m-b a^{3}$ & $\mathrm{ba}^{3}$ & $\mathrm{te}^{33}$ \\
\hline
\end{tabular}




\begin{tabular}{|c|c|c|c|c|c|c|}
\hline 820.0 & dim; dark & 暗（房子很暗） & 它_了 & & $\gamma \dot{1}^{1}$ & \\
\hline 821.0 & clear (sky) & 晴 & 它_了 & & $\mathrm{te}^{\mathrm{L}}$ & \\
\hline 822.0 & overcast & 阴 & 它_了 & & $\mathrm{ti}^{1}$ & $\mathrm{ni}^{33}$ \\
\hline 823.0 & full & 满 & 它_了 & ${ }^{*} \mathrm{~m}-\mathrm{blin}^{3}$ & $\mathrm{bi}^{3}$ & pəy $^{33}$ \\
\hline 824.0 & beautiful & 美丽 $\{$ 漂亮 $\}$ & 它_了 & & $m \varepsilon^{2}$ & nəy ${ }^{33}$ \\
\hline 825.0 & ugly & 丑 & 它_了 & & $\mathrm{he}^{1}$ & $\mathrm{ma}^{33} 1 \mathrm{a}^{21}$ \\
\hline 826.0 & fat (person) & 胖 & 它_了 & $*$ tsu $^{1}$ & $\operatorname{ts}^{\mathrm{h}} \mathrm{u}^{1}$ & $\operatorname{ts}^{\mathrm{h}} \mathrm{u}^{55}$ \\
\hline 827.0 & fat; fatty (meat) & 肥 (肉肥) & 它_了 & $* \mathrm{tsi}^{1}$ & $\operatorname{ts}^{\mathrm{h}} \mathrm{u}^{1}$ & $\operatorname{ts}^{\mathrm{h}} \mathrm{u}^{55}$ \\
\hline 828.0 & lean & 瘦（瘦肉） & 它_了 & & $n e^{\mathrm{L}}$ & $\mathrm{t} 6 \mathrm{o}^{55}$ \\
\hline 829.0 & skinny; thin & 瘦（人瘦） & 它_了 & & $\mathrm{gy}^{1}$ & $\mathrm{t} 6 \mathrm{o}^{55}$ \\
\hline 830.0 & clean & 干净 & 它_了 & & $x{ }^{1}$ & $\mathrm{xa}^{55}$ \\
\hline & & & & ${ }^{*} \mathrm{kre}^{2} \& * \mathrm{kyit}^{\mathrm{H}} \&$ & & \\
\hline 831.0 & dirty & 脏 & 它_了 & $*(\mathrm{C}) \mathrm{cak}^{\mathrm{H} / \mathrm{L}}$ & & ts $^{\mathrm{h}} \mathrm{a}^{33}$ \\
\hline 832.0 & old (person) & 老（老人） & 它_了 & $* \operatorname{may}^{2}$ & $\operatorname{man}^{2}$ & $\mathrm{mu}^{21}$ \\
\hline 833.0 & young & 年轻 & 它_了 & $*$ nay $^{2} /{ }^{1}$ & $1 \underline{e}^{\mathrm{L}}$ & $1 a^{33}$ \\
\hline 834.0 & good & 好（东西好） & 它_了 & $\begin{array}{l}*^{*}-\min ^{1} / 2 / 3 \\
* \mathrm{~m}-\mathrm{d}(\mathrm{y}) \mathrm{akL}\end{array}$ & $m \varepsilon^{2}$ & $b^{21}$ \\
\hline 835.0 & bad & 坏（人坏） & 它_了 & *pyakH > destroy & $\mathrm{p}^{\mathrm{h}} \underline{e}^{\mathrm{H}}$ & $\mathrm{t}^{\mathrm{h}} \mathrm{i}^{33}$ \\
\hline 836.0 & fast & 快（走得快） & 它_了 & ${ }^{*} \mathrm{~m}-\mathrm{gi}{ }^{1} \& *[$ waj $]$ & ?mjȳH & \\
\hline 837.0 & slow & 慢（走得慢） & 它_了 & & $\operatorname{gja}^{1}$ & $\mathrm{a}^{21} \mathrm{za}^{33}$ \\
\hline 838.0 & wet & 湿（衣服湿） & 它_了 & $*(\mathrm{~s})-\operatorname{nak}^{\mathrm{H} / \mathrm{L}} \& *$ jwwap $/ \mathrm{at}^{\mathrm{H}}$ & $\mathrm{t} \int^{\mathrm{h}} \dot{\mathrm{t}}^{2}$ & $n \partial^{21}$ \\
\hline 839.0 & dry & 干（衣服干） & 它_了 & $*_{\mathrm{s}-\mathrm{we}}{ }^{2} \& *_{\mathrm{gwe}} \mathrm{gw}^{3}$ & $f \varepsilon^{3}$ & $x \partial^{33}$ \\
\hline 840.0 & new & 新 & 它_了 & $* \mathrm{C}-\int \mathrm{ik}^{\mathrm{L}}$ & $\mathrm{X}_{\underline{i}^{\mathrm{L}}}$ & $\mathrm{Sl}^{33}$ \\
\hline 841.0 & old & 旧 & 它_了 & $* 2-\mathrm{bi}^{2} \& * 2-\mathrm{li}^{1}$ & $2 \mathrm{li}^{1}$ & $\mathrm{pi}^{55}$ \\
\hline 842.0 & raw; unripe & 生（生肉） & & & $\mathrm{d}_{3} \mathrm{i}^{2}$ & \\
\hline 843.0 & cooked; ripe & 熟（熟肉） & 它_了 & $*_{\mathrm{s}-\mathrm{min}^{3}}$ & $2 \mathrm{mi}^{3}$ & $\mathrm{mi}^{33}$ \\
\hline 844.0 & early & 早（来得早） & 它_了 & & $n e^{L}$ & $\mathrm{~S}^{21}$ \\
\hline 845.0 & late & 迟（来迟了） & 它_了 & $*(\mathrm{k})-1(\mathrm{y}) \mathrm{ay}^{3}$ & $\mathrm{mja}^{3}$ & \\
\hline 846.0 & easy & 容易 & 它_了 & $* \mathrm{sa}^{1}$ & $1 \varepsilon^{1}$ & $\operatorname{ts}^{\mathrm{h}} \mathrm{a}^{55} \mathrm{ts}^{\mathrm{h}} \mathrm{a}^{55}$ \\
\hline 847.0 & difficult & 难 & 它_了 & $* \mathrm{kak}^{\mathrm{H}} \& * \mathrm{2} / \mathrm{s}-\mathrm{ra}^{2}$ & $\int \underline{a}^{\mathrm{L}}$ & $\mathrm{k}^{\mathrm{h}} \mathrm{a}^{55}$ \\
\hline 848.0 & hot (temp.) & 热 & 它_了 & $*$ ?-log ${ }^{1} \& *$ tsa $^{1}$ & $\operatorname{ts}^{\mathrm{h}} \mathrm{a}^{1}$ & $\mathrm{vu}^{55}$ \\
\hline 849.0 & cold (weather) & 冷 & 它_了 & ${ }^{*} \mathrm{C}$-grak ${ }^{\mathrm{H}}$ & $\mathrm{gje}^{\mathrm{H}}$ & \\
\hline 849.1 & cold (body) & & & & gjay $^{1}$ & $\mathrm{t}_{\varphi} \mathrm{u}^{33}$ \\
\hline 850.0 & warm & 暖和 & 它_了 & $* \operatorname{lum}^{1}$ & $1 y^{1}$ & $\mathrm{ni}^{21}$ \\
\hline 851.0 & cool & 凉快 & 它_了 & $*(\mathrm{C})-\mathrm{m}-\mathrm{ga \eta}^{1} \& \quad{ }^{*} \mathrm{C}-\mathrm{cok}^{\mathrm{L}}$ & & \\
\hline 852.0 & sour & 酸 & 它_了 & *2-kyin ${ }^{1}$ & $t \int \mathrm{e}^{1}$ & $\operatorname{tc} \mathrm{i}^{55}$ \\
\hline 853.0 & sweet & 甜 & 它_了 & $* \mathrm{kyo}^{1}$ & $\mathrm{t}^{\mathrm{h}} \dot{\mathrm{i}}^{1}$ & $t 6^{\mathrm{h}} \mathrm{u}^{55}$ \\
\hline 854.0 & bitter & 苦 & 它_了 & $* \mathrm{ka}^{2}$ & $\mathrm{k}^{\mathrm{h}} \mathrm{a}^{2}$ & $\mathrm{k}^{\mathrm{h}} \mathrm{a}^{33}$ \\
\hline 855.0 & hot (spicy) & 辣 & 它_了 & ${ }^{*} \mathrm{pi}^{1}$ & $\mathrm{p}^{\mathrm{h}} \mathrm{e}^{1}$ & $\mathrm{p}^{\mathrm{h}^{5} 55}$ \\
\hline 856.0 & salty & 咸 & 它_了 & & & \\
\hline 857.0 & delicious & 好吃 & 它_了 & $*^{\text {may }^{1}}$ & $m e^{1}$ & $\mathrm{k}^{\mathrm{h}} \mathrm{\partial}^{55}$ \\
\hline 858.0 & insipid & 没味道 & 它_了 & & $b j \underline{\varepsilon}^{\mathrm{H}}$ & \\
\hline 859.0 & fragrant & 香（花香） & 它_了 & $*[\mathrm{~h} \ni \mathrm{m}]$ & sy $^{1}\left(b^{2}\right) n y^{1}$ & xon $^{33}$ \\
\hline 860.0 & stinky & 臭 & 它_了 & $*$ ?-nam ${ }^{2}$ & by $^{2} n y^{1}$ & $\mathrm{pi}^{21}$ \\
\hline 861.0 & fishy (smell) & 腥（鱼腥） & 它_了 & & $\mathrm{dzi}^{2} n y^{1}$ & \\
\hline 862.0 & rotten & 腐烂的 & 它_了 & $* \mathrm{~m}-\mathrm{bup}^{\mathrm{L}} \& * 1-\mathrm{kri}^{2}$ & $\mathrm{p}^{\mathrm{h}^{2}}{ }^{2}$ & $\mathrm{po}^{21}$ \\
\hline 863.0 & full (stomach) & 饱 & 他_了 & & $\mathrm{bo}^{\mathrm{H}}$ & $\mathrm{pu}^{31}$ \\
\hline 864.0 & hungry & 饿 & 他_过 & ${ }^{*} \mathrm{C}-\mathrm{mwat}^{\mathrm{L}}$ & $\mathrm{mi}^{\mathrm{L}}$ & $\mathrm{mi}^{31}$ \\
\hline 865.0 & thirsty & 渴 & 他_过 & ${ }^{*} \mathrm{C}-\mathrm{sip}^{\mathrm{L}}$ & $\mathrm{si}^{\mathrm{L}}$ & $\mathrm{so}^{33}$ \\
\hline 866.0 & tired & 累（疲乏/疲劳/疲倦） & 他_过 & $*[\mathrm{~h} ə]$ & & $\mathrm{ma}^{21} \mathrm{ka}^{21}$ \\
\hline
\end{tabular}




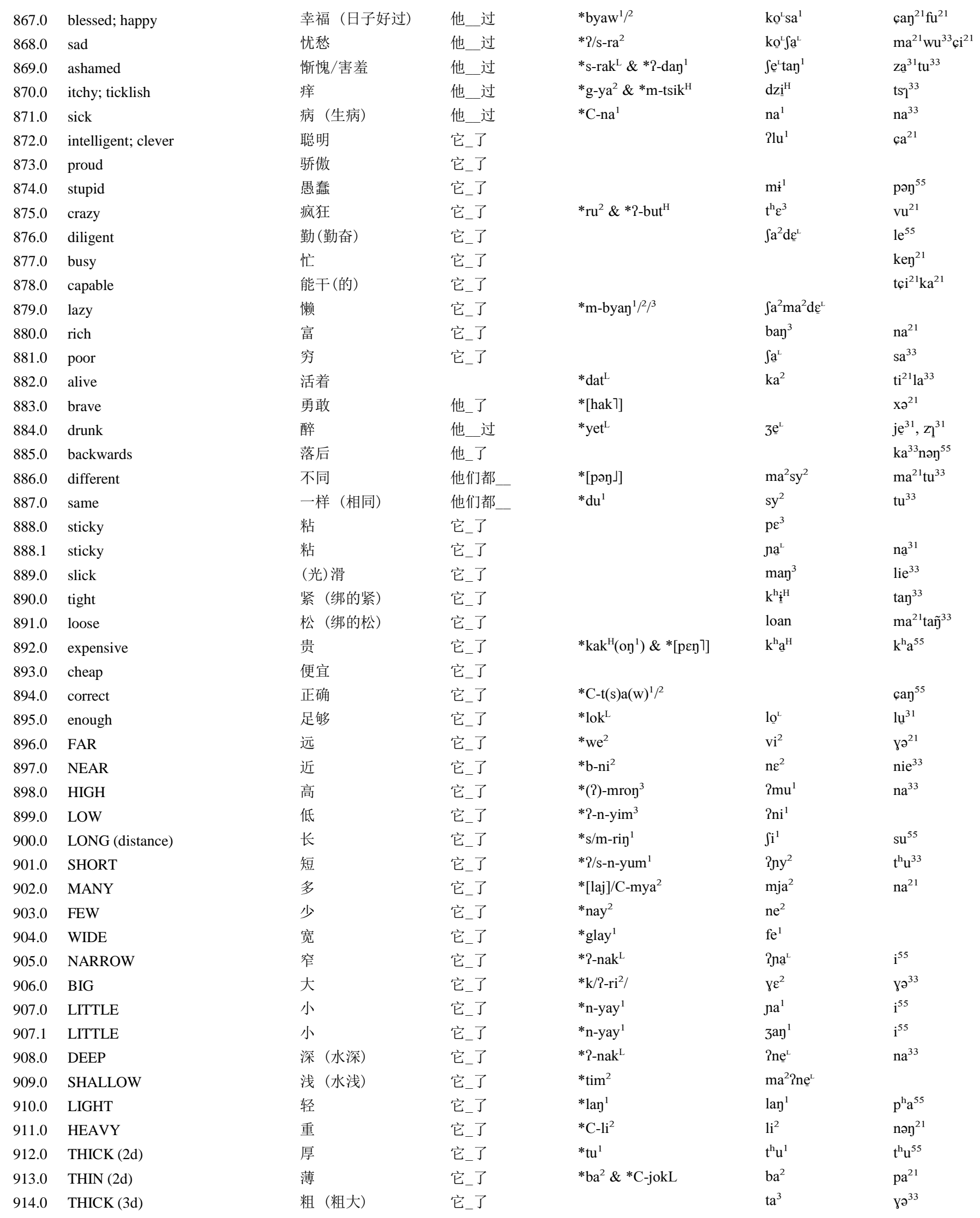




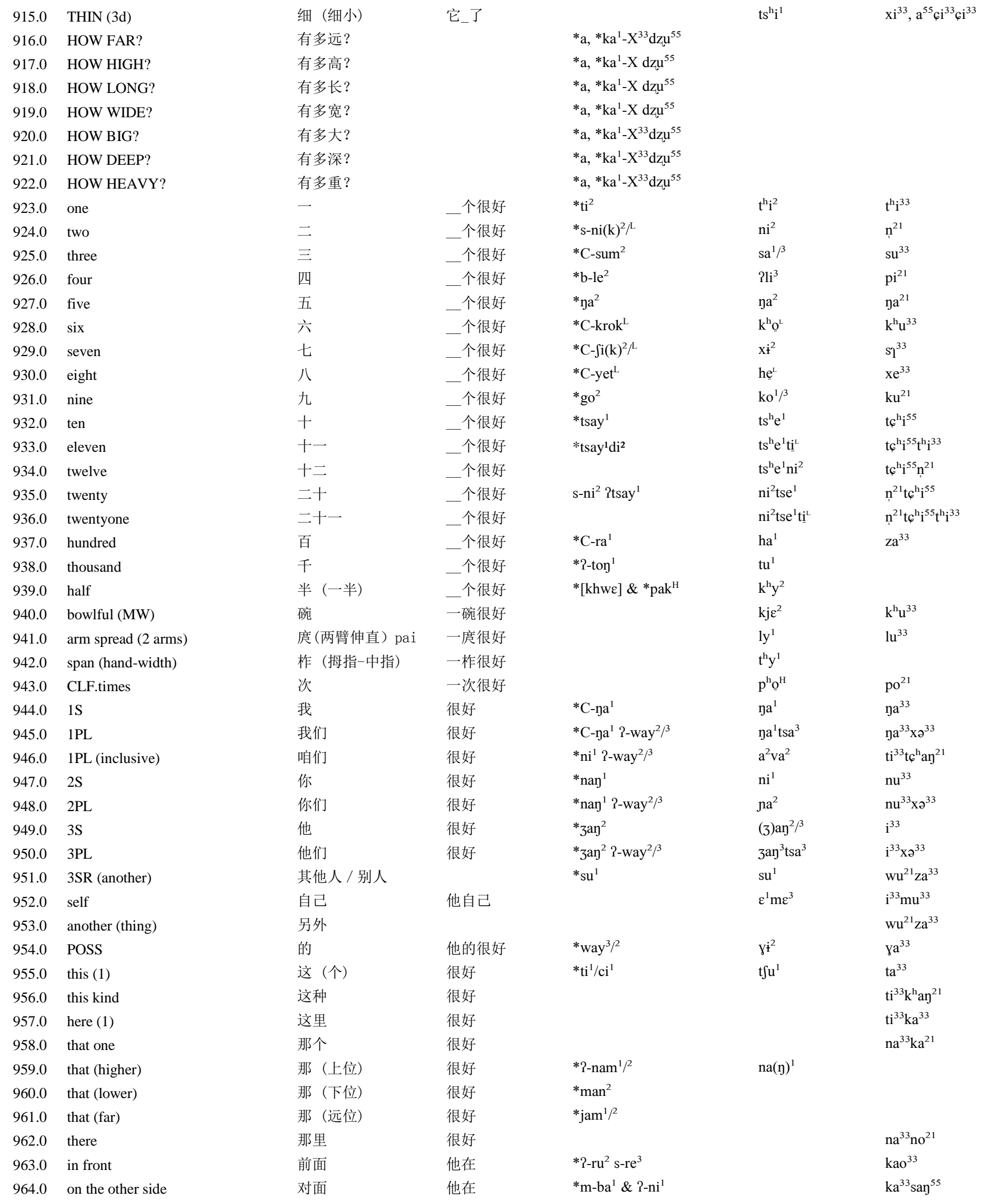




\begin{tabular}{|c|c|c|c|c|c|c|}
\hline 965.0 & behind & 后面 & 他在 & $* \mathrm{C}^{-\mathrm{ka}^{2}} \sim \mathrm{C}-\mathrm{kok}^{\mathrm{L}}$ 1-nok ${ }^{\mathrm{L}}$ & $i^{2} \mathrm{se}^{1}$ & $\mathrm{ka}^{33} \mathrm{nə \eta}^{55}$ \\
\hline 966.0 & between & 中间 & 他在 & ${ }^{*} \mathrm{C}-\mathrm{kra}^{1}$ & $\mathrm{ka}^{\mathrm{L}} \mathrm{kay}^{1}$ & $\mathrm{y}^{55} \mathrm{ka \eta}^{55}$ \\
\hline 967.0 & left & 左边 & 他在 & $*$ b-way ${ }^{2} \&$ C-may ${ }^{2}$ & $2 v \varepsilon^{2}$ & $\mathrm{a}^{55} \mathrm{fi}^{33}$ \\
\hline 968.0 & right & 右边 & 他在 & s-ya ${ }^{1} /$ nma $^{1}$ & $3^{a^{1}}$ & $\mathrm{a}^{33} \mathrm{ji}^{21}, \mathrm{a}^{33} \mathrm{Zl}^{21}$ \\
\hline 969.0 & beside & 旁边 & 他在 & & $\mathrm{ba}^{2} \mathrm{ta}^{3}$ & $\mathrm{p}^{\mathrm{h}} \mathrm{i}^{55} \mathrm{tcu} \mathrm{u}^{55}$ \\
\hline 970.0 & side & 边 & & $* \mathrm{pa}^{2}$ & $\mathrm{ba}^{2} \mathrm{dzi}{ }^{1}$ & $\mathrm{p}^{\mathrm{h}} \mathrm{i}^{55} \mathrm{t} \mathrm{u}^{55}$ \\
\hline 971.0 & upon & 上面 & 他在 & $* \operatorname{tak}^{\mathrm{H}}$ & $\mathrm{ka}^{\mathrm{L}}$ & $\mathrm{a}^{33} \mathrm{t}^{\mathrm{h}} \mathrm{a}^{55}$ \\
\hline 972.0 & beneath & 下面 & 他在 & $*$ Tok $^{\mathrm{H}} / \mathrm{ok}^{\mathrm{L}}$ & & $\mathrm{ti}^{33} \mathrm{ku}^{33}, \mathrm{a}^{21} \mathrm{k}^{33}$ \\
\hline 973.0 & inside & 里面 & 他在 & $* \mathrm{klo}^{1}$ & $\mathrm{k}^{\mathrm{h} \mathrm{jo}^{2}}$ & $\mathrm{ni}^{55} \mathrm{k}^{\mathrm{h}} ə \mathrm{\eta}^{55}$ \\
\hline & & & & & & $\mathrm{ka}^{21} \mathrm{wai}^{33}$ \\
\hline 974.0 & outside & 外面 & 他在 & & & $\mathrm{ka}^{21} \mathrm{wa}^{33}$ \\
\hline 975.0 & everywhere & 到处 & & & & $\mathrm{t}^{\mathrm{h}} \mathrm{i}^{33} \operatorname{san}^{55} \operatorname{san}^{55}$ \\
\hline 976.0 & who? & 谁? & 打我? & $*$ ?əsu ${ }^{1}$ & $\mathrm{a}^{2} \mathrm{sa}^{2}$ & $a^{21} s^{33}$ \\
\hline 977.0 & what? & 什么? & 他说_? & $*$ ?әје ${ }^{2} \& *$ ?әра ${ }^{1} \& *$ ?ətap ${ }^{L}$ & $a^{1} \operatorname{tsa}^{1}$ & $\mathrm{a}^{55} \mathrm{\gamma}^{33}, \mathrm{t}^{\mathrm{h}} \mathrm{a}^{21} \mathrm{\gamma} \mathrm{\partial}^{33}$ \\
\hline 978.0 & where? & 哪里? & 他去_? & *2əlam ${ }^{3}$ & $\mathrm{a}^{2} \mathrm{di}^{1}$ & $\mathrm{a}^{21} \operatorname{tə\eta }^{55}$ \\
\hline 979.0 & why? & 为什么? & 他_去? & & $a^{1}$ tsa $^{1} \mathrm{pe}^{1}$ & $\mathrm{a}^{21} \mathrm{ti}^{33} \mathrm{xa}^{55}$ \\
\hline 980.0 & which (one)? & 哪 (一个)? & 他要_? & & $a^{2} d a^{1}$ & $\begin{array}{l}\mathrm{a}^{21} \operatorname{tə\eta }^{55} \\
\mathrm{t}^{\mathrm{h}} \mathrm{i}^{33} \mathrm{ma}^{33} \mathrm{vi}^{33}\end{array}$ \\
\hline 981.0 & how? & 怎么? & 他_去? & \multicolumn{3}{|c|}{ 'ADV/RELQ + choose' cf. 811} \\
\hline 982.0 & how much? & 多少? & 你要_? & $*$ ?əC-mya ${ }^{1}$ & $\mathrm{a}^{1} \mathrm{ma}^{3}$ & $\mathrm{k}^{\mathrm{h}} \mathrm{a}^{33} \mathrm{sa}^{33}$ \\
\hline 983.0 & now & 现在 & 他_去 & ${ }^{*} \mathrm{~m}$-but ${ }^{\mathrm{L}} \&$ Pəmay ${ }^{1}$ & $\mathrm{t} \int \mathrm{u}^{1} \mathrm{t}^{\mathrm{h}} \mathrm{a}^{1}$ & $\mathrm{ti}^{33} \mathrm{xə \eta}^{55}$ \\
\hline 984.0 & just now & 刚才 & 他_去 & & $a^{2} \int u^{3}$ & \\
\hline 985.0 & before (sequential) & 先（先去） & 他_去 & & & $\mathrm{kao}^{33}$ \\
\hline 986.0 & after & 后（后去） & 他_去 & & & $\mathrm{ka}^{33} \mathrm{nəy}^{55}$ \\
\hline 987.0 & before (temporal) & 以前 & & & & \\
\hline 988.0 & formerly & 从前 & & & & \\
\hline 989.0 & already & 已经 & 他_走了 & & & \\
\hline 990.0 & immediately & 立刻 & 他_去 & & & \\
\hline 991.0 & frequently & 常常（常常来） & 他_去 & & $b \dot{t}^{1}$ & $\mathrm{t}^{\mathrm{h}} \mathrm{i}^{33} 6 \mathrm{a}^{33}$ \\
\hline 992.0 & slowly & 慢慢（慢慢走） & 他_去 & $* \mathrm{ya}^{3} / \mathrm{yak}^{\mathrm{L}}$ & $a^{2} d^{3} d^{3}$ & $a^{21} 1 o^{33}$ \\
\hline 993.0 & quickly & 快快（快快走） & 他_去 & ${ }^{*} \operatorname{mran}^{1} \& *[$ hak $\left.\rceil\right]$ & 2mjy ${ }^{\mathrm{H}}$ & $\mathrm{mi}^{33} \mathrm{mi}^{33}$ \\
\hline 994.0 & very & 很（很漂亮） & 她很漂亮 & & & $\mathrm{kai}^{33}$ \\
\hline 995.0 & most & 最（最大） & 它是最大 & & & \\
\hline 996.0 & all & 都（大家都来） & 大家都来 & & & \\
\hline 997.0 & again & 再（明天再来） & 明天再来 & $* \mathrm{~m}-\mathrm{gu}^{3}$ & & \\
\hline 998.0 & really; certainly & 一定（我一定去） & & ${ }^{*} \mathrm{~m}$-day ${ }^{1}$ & & \\
\hline 999.0 & not (NEG) & 不 (他不来) & 他不来 & $* \mathrm{ma}^{2}$ & $\mathrm{ma}^{2}$ & $\mathrm{ma}^{21}$ \\
\hline 1000.0 & don't & 别（别去） & & $* \mathrm{ta}^{2}$ & $\mathrm{t}^{\mathrm{h}} \mathrm{a}^{2}$ & $\mathrm{t}^{\mathrm{h}} \mathrm{a}^{33}$ \\
\hline 1001.0 & each other & 互相 & & $*_{\mathrm{m}}-\mathrm{dak}^{\mathrm{L}}$ & & \\
\hline
\end{tabular}

